Prepared in cooperation with the National Park Service

Concentrations of Metals and Trace Elements in Aquatic Biota Associated with Abandoned Mine Lands in the Whiskeytown National Recreation Area and Nearby Clear Creek Watershed, Shasta County, Northwestern California, 2002-2003

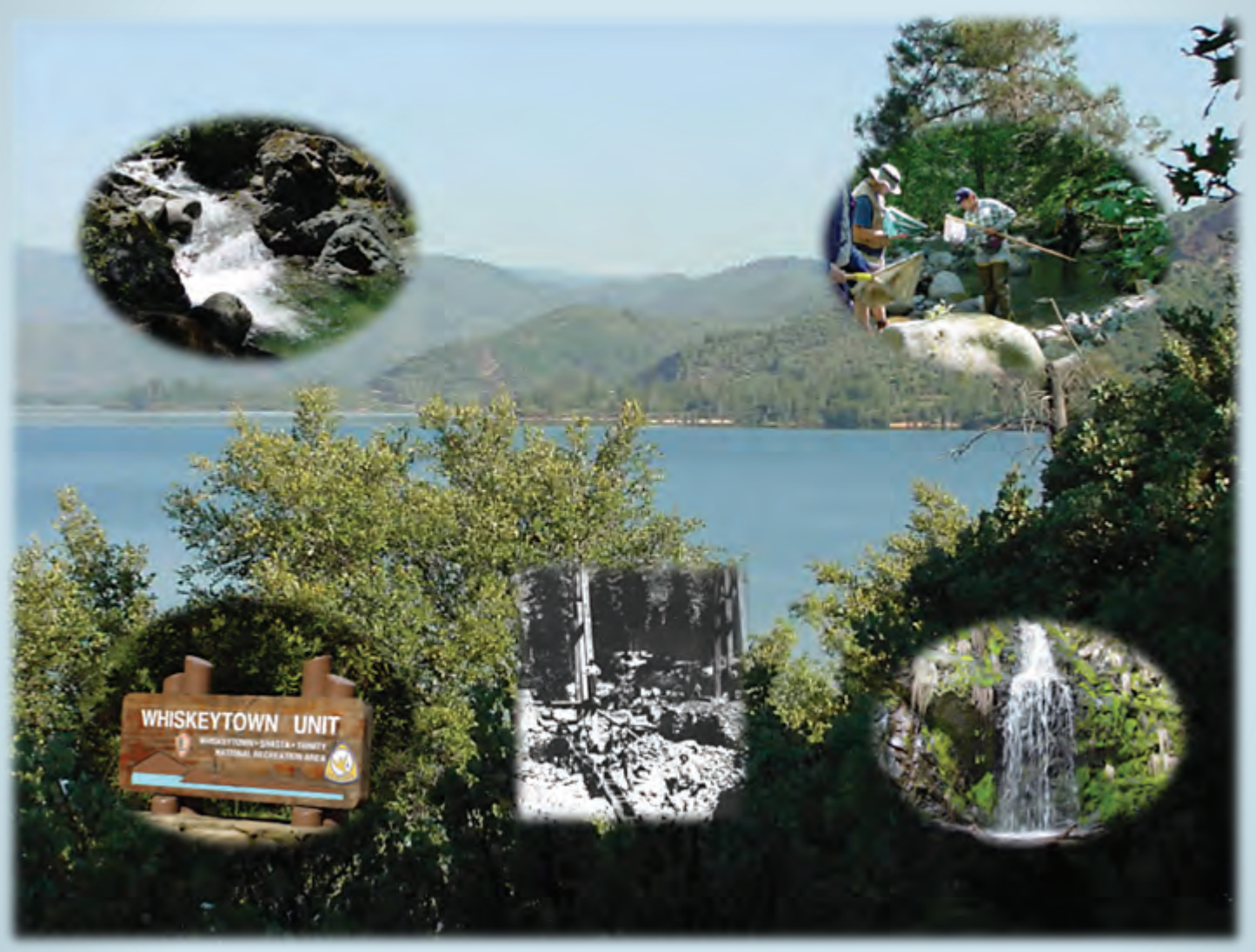

Open-File Report 2015-1077 
Cover: Montage of Whiskeytown National Recreation Area.

Background: Whiskeytown Lake.

Clockwise from upper left: Brandy Creek; sampling invertebrates in Brandy Creek; Slate Creek Falls; miners in Whiskey Creek (courtesy of Whiskeytown National

Recreation Area archives); and Whiskeytown unit sign. (Original photographs by Roger Hothem and David Kelly.) 


\section{Concentrations of Metals and Trace Elements in Aquatic Biota Associated with Abandoned Mine Lands in the Whiskeytown National Recreation Area and Nearby Clear Creek Watershed, Shasta County, Northwestern California, 2002-2003}

By Roger L. Hothem, Jason T. May, Jennifer K. Gibson, and Brianne E. Brussee

Prepared in cooperation with the National Park Service

Open-File Report 2015-1077

U.S. Department of the Interior

U.S. Geological Survey 


\section{U.S. Department of the Interior SALLY JEWELL, Secretary}

\section{U.S. Geological Survey \\ Suzette M. Kimball, Acting Director}

U.S. Geological Survey, Reston, Virginia: 2015

For more information on the USGS—-the Federal source for science about the Earth,

its natural and living resources, natural hazards, and the environment-visit

http://www.usgs.gov or call 1-888-ASK-USGS (1-888-275-8747)

For an overview of USGS information products, including maps, imagery, and publications, visit http://www.usgs.gov/pubprod

Any use of trade, firm, or product names is for descriptive purposes only and does not imply endorsement by the U.S. Government.

Although this information product, for the most part, is in the public domain, it also may contain copyrighted materials as noted in the text. Permission to reproduce copyrighted items must be secured from the copyright owner.

Suggested citation:

Hothem, R.L., May, J.T., Gibson, J.K., and Brussee, B.E., 2015, Concentrations of metals and trace elements in aquatic biota associated with abandoned mine lands in the Whiskeytown National

Recreation Area and nearby Clear Creek watershed, Shasta County, northwestern California, 20022003: U.S. Geological Survey Open-File Report 2015-1077, 64 p., http://dx.doi.org/10.3133/ofr20151077.

ISSN 2331-1258 (online) 


\section{Contents}

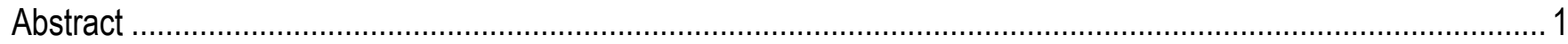

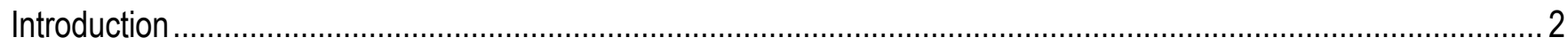

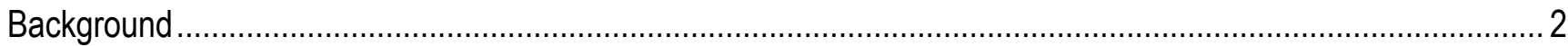

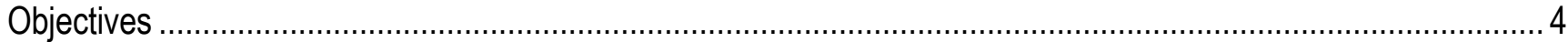

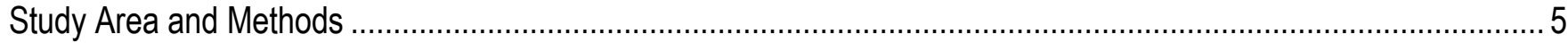

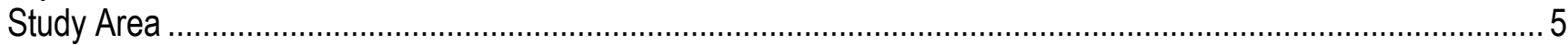

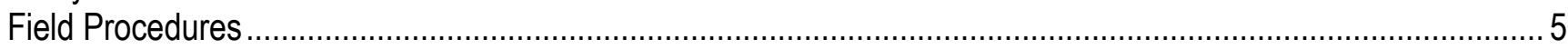

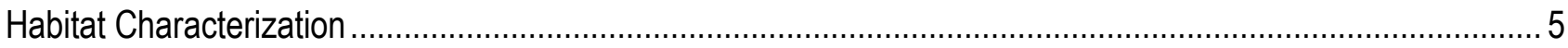

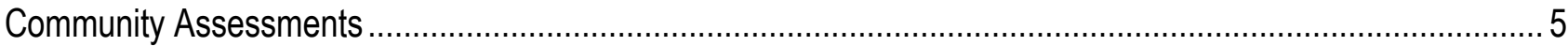

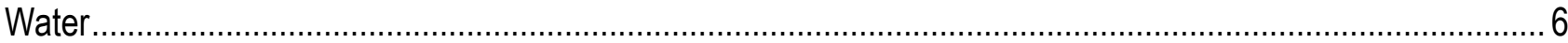

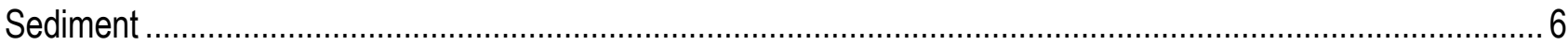

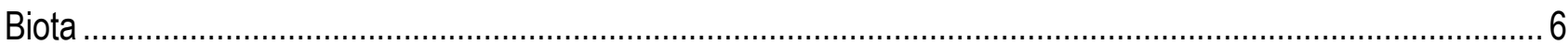

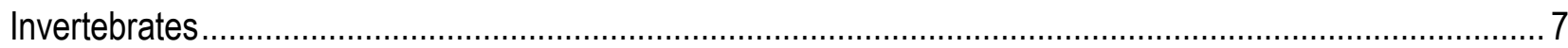

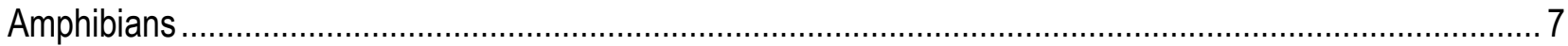

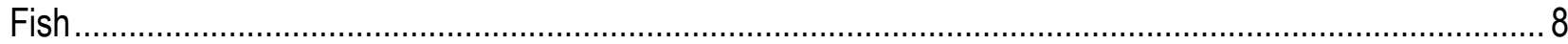

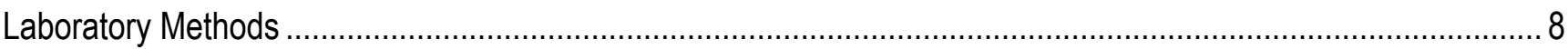

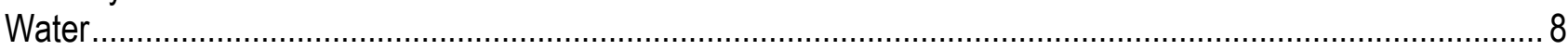

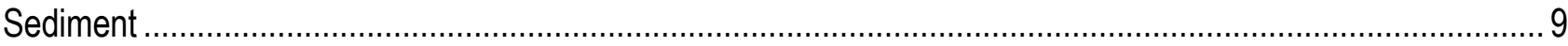

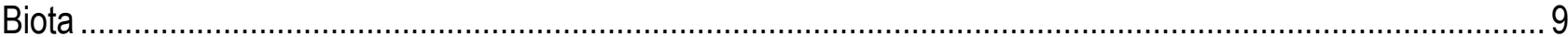

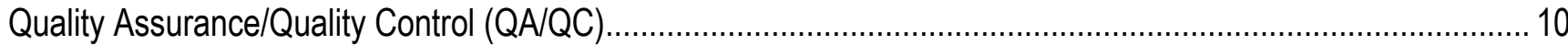

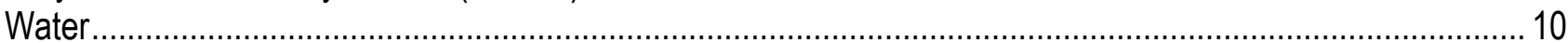

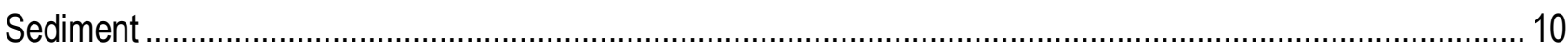

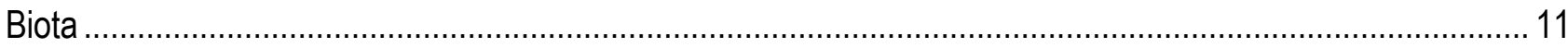

Data Analyses

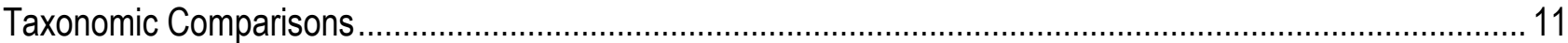

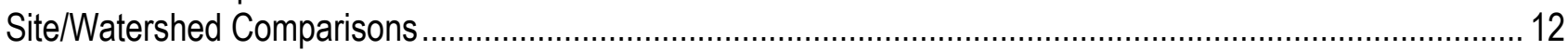

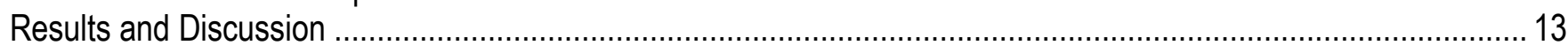

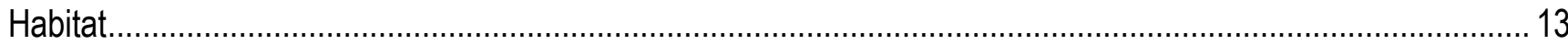

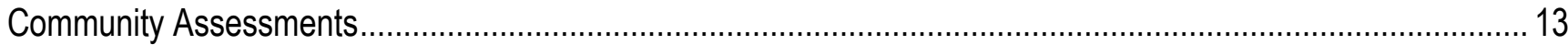

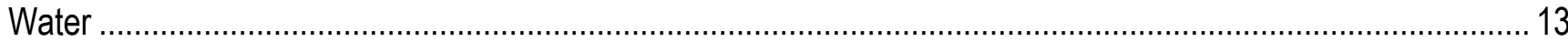

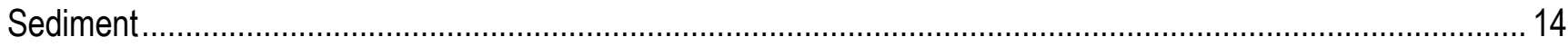

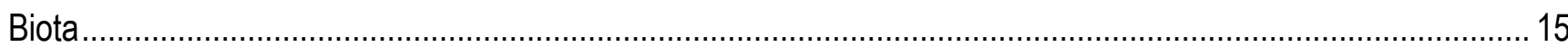

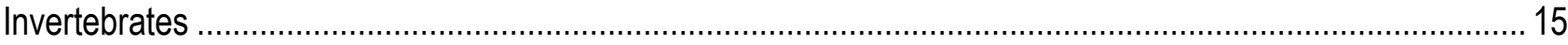

Amphibians

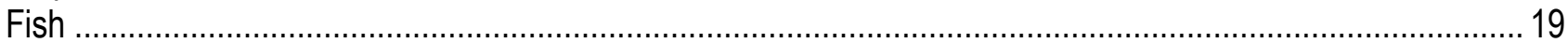

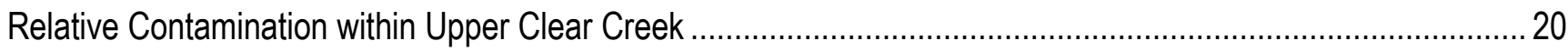

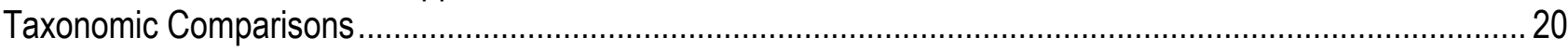

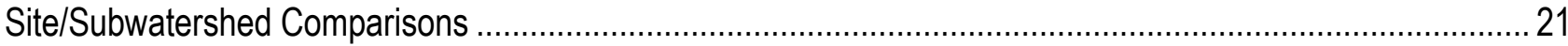

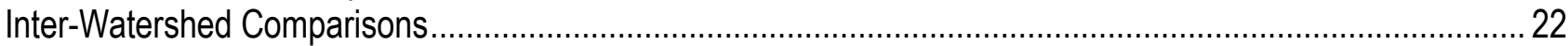

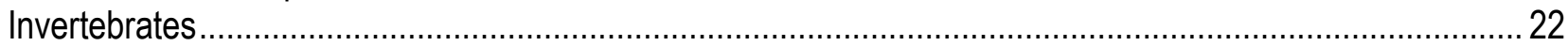

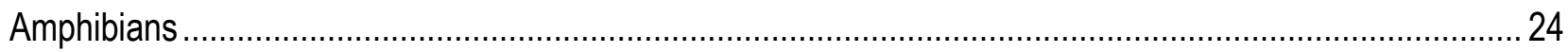

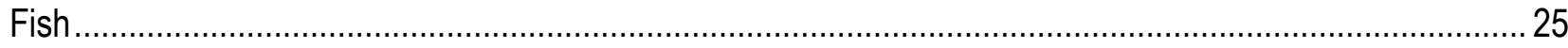

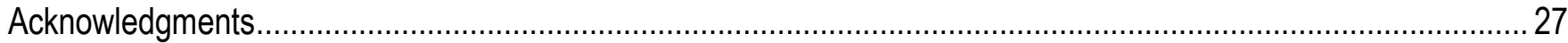

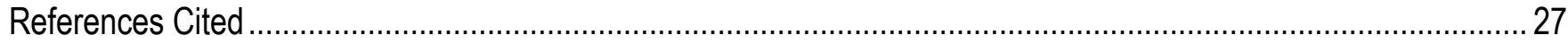

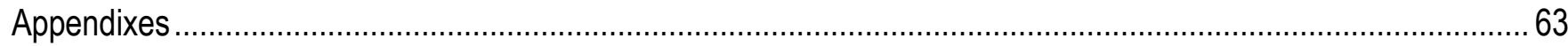




\section{Figures}

Figure 1. Map showing sites sampled for biota in the Whiskeytown National Recreation Area and nearby Clear Creek watershed, northwestern California, 2002-03...

Figure 2. Bar graphs showing geometric mean (and range) of arsenic (As) concentrations (micrograms per gram, dry weight $[\mu \mathrm{g} / \mathrm{g}, \mathrm{dw}]$ ) in larval dobsonflies (Megaloptera: Corydalidae), adult water striders (Hemiptera: Gerridae), larval dragonflies (Odonata: Gomphidae), and larval stoneflies (Plecoptera: Perlidae) collected from Whiskeytown National Recreation Area and vicinity, northwestern California, 2002 (shaded bars) and 2003 (clear bars).

Figure 3. Bar graphs showing geometric mean (and range) of cadmium (Cd) concentrations (micrograms per gram, dry weight [ $\mu \mathrm{g} / \mathrm{g}, \mathrm{dw}]$ ) in larval dobsonflies (Megaloptera: Corydalidae), adult water striders (Hemiptera: Gerridae), larval dragonflies (Odonata: Gomphidae), and larval stoneflies (Plecoptera: Perlidae) collected from Whiskeytown National Recreation Area and vicinity, northwestern California, 2002 (shaded) and 2003 (clear)

Figure 4. Bar graphs showing geometric mean (and range) of chromium (Cr) concentrations (micrograms per gram, dry weight $[\mu \mathrm{g} / \mathrm{g}, \mathrm{dw}]$ ) in larval dobsonflies (Megaloptera: Corydalidae), adult water striders (Hemiptera: Gerridae), larval dragonflies (Odonata: Gomphidae), and larval stoneflies (Plecoptera: Perlidae) collected from Whiskeytown National Recreation Area and vicinity, northwestern California, 2002 (shaded) and 2003 (clear) .... 35 Figure 5. Bar graphs showing geometric mean (and range) of copper $(\mathrm{Cu})$ concentrations (micrograms per gram, dry weight $[\mu \mathrm{g} / \mathrm{g}, \mathrm{dw}]$ ) in larval dobsonflies (Megaloptera: Corydalidae), adult water striders (Hemiptera: Gerridae), larval dragonflies (Odonata: Gomphidae), and larval stoneflies (Plecoptera: Perlidae) collected from Whiskeytown National Recreation Area and vicinity, northwestern California, 2002 (shaded) and 2003 (clear) ..... 36 Figure 6. Bar graphs showing geometric mean (and range) of total mercury $\left(\mathrm{Hg}_{\mathrm{T}}\right.$ ) concentrations (micrograms per gram, wet weight $[\mu \mathrm{g} / \mathrm{g}, \mathrm{ww}]$ ) in larval dobsonflies (Megaloptera: Corydalidae), adult water striders (Hemiptera: Gerridae), larval dragonflies (Odonata: Gomphidae), and larval stoneflies (Plecoptera: Perlidae) collected from Whiskeytown National Recreation Area and vicinity, northwestern California, 2002 (shaded) and 2003 (clear).

Figure 7. Bar graphs showing geometric mean (and range) of nickel (Ni) concentrations (micrograms per gram, dry weight $[(\mu \mathrm{g} / \mathrm{g}, \mathrm{dw}])$ in larval dobsonflies (Megaloptera: Corydalidae), adult water striders (Hemiptera: Gerridae), larval dragonflies (Odonata: Gomphidae), and larval stoneflies (Plecoptera: Perlidae) collected from Whiskeytown National Recreation Area and vicinity, northwestern California, 2002 (shaded) and 2003 (clear)

Figure 8. Bar graphs showing geometric mean (and range) of lead $(\mathrm{Pb})$ concentrations (micrograms per gram, dry weight $[\mu \mathrm{g} / \mathrm{g}, \mathrm{dw}]$ ) in larval dobsonflies (Megaloptera: Corydalidae), adult water striders (Hemiptera: Gerridae), larval dragonflies (Odonata: Gomphidae), and larval stoneflies (Plecoptera: Perlidae) collected from Whiskeytown National Recreation Area and vicinity, northwestern California, 2002 (shaded) and 2003 (clear)

Figure 9. Bar graphs showing geometric mean (and range) of selenium (Se) concentrations (micrograms per gram, dry weight $[\mu \mathrm{g} / \mathrm{g}, \mathrm{dw}])$ in larval dobsonflies (Megaloptera: Corydalidae), adult water striders (Hemiptera: Gerridae), larval dragonflies (Odonata: Gomphidae), and larval stoneflies (Plecoptera: Perlidae) collected from Whiskeytown National Recreation Area and vicinity, northwestern California, 2002 (shaded) and 2003 (clear)

Figure 10. Bar graphs showing geometric mean (and range) of zinc $(\mathrm{Zn})$ concentrations (micrograms per gram, dry weight $[\mu \mathrm{g} / \mathrm{g}, \mathrm{dw}]$ ) in larval dobsonflies (Megaloptera: Corydalidae), adult water striders (Hemiptera: Gerridae), larval dragonflies (Odonata: Gomphidae), and larval stoneflies (Plecoptera: Perlidae) collected from Whiskeytown National Recreation Area and vicinity, northwestern California, 2002 (shaded) and 2003 (clear) 
Figure 11. Bar graph showing geometric mean (and range and sample size) of arsenic (As) concentrations (micrograms per gram, dry weight $[\mu \mathrm{g} / \mathrm{g}, \mathrm{dw}]$ ) in adult bullfrogs (BULL; Lithobates catesbeianus), larval bullfrogs (BFTP), foothill yellow-legged frogs (FYLF; Rana boylii), and Pacific chorus frogs (PACF; Pseudacris regilla) collected from Whiskeytown National Recreation Area and vicinity, northwestern California, 2002 (shaded) and 2003 (clear)

Figure 12. Bar graph showing geometric mean (and range and sample size) of cadmium (Cd) concentrations (micrograms per gram, dry weight $[\mu \mathrm{g} / \mathrm{g}, \mathrm{dw}]$ ) in adult bullfrogs (BULL; Lithobates catesbeianus), larval bullfrogs (BFTP), foothill yellow-legged frogs (FYLF; Rana boylii), and Pacific chorus frogs (PACF; Pseudacris regilla) collected from Whiskeytown National Recreation Area and vicinity, northwestern California, 2002 (shaded) and 2003 (clear)

Figure 13. Bar graph showing geometric mean (and range and sample size) of chromium $(\mathrm{Cr})$ concentrations (micrograms per gram, dry weight $[\mu \mathrm{g} / \mathrm{g}, \mathrm{dw}]$ ) in adult bullfrogs (BULL; Lithobates catesbeianus), larval bullfrogs (BFTP), foothill yellow-legged frogs (FYLF; Rana boylii), and Pacific chorus frogs (PACF; Pseudacris regilla) collected from Whiskeytown National Recreation Area and vicinity, northwestern California, 2002 (shaded) and 2003 (clear)...

Figure 14. Bar graph showing geometric mean (and range and sample size) of copper $\mathrm{Cu}$ ) concentrations (micrograms per gram, dry weight $[\mu \mathrm{g} / \mathrm{g}, \mathrm{dw}]$ ) in adult bullfrogs (BULL; Lithobates catesbeianus), larval bullfrogs (BFTP), foothill yellow-legged frogs (FYLF; Rana boylii), and Pacific chorus frogs (PACF; Pseudacris regilla) collected from Whiskeytown National Recreation Area and vicinity, northwestern California, 2002 (shaded) and 2003 (clear).......

Figure 15. Bar graph showing geometric mean (and range and sample size) of total mercury $\left(\mathrm{Hg}_{\mathrm{T}}\right)$ concentrations (micrograms per gram, wet weight $[\mu \mathrm{g} / \mathrm{g}, \mathrm{ww}]$ ) in adult bullfrogs (BULL; Lithobates catesbeianus), larval bullfrogs (BFTP), foothill yellow-legged frogs (FYLF; Rana boylii), and Pacific chorus frogs (PACF; Pseudacris regilla) collected from Whiskeytown National Recreation Area and vicinity, northwestern California, 2002 (shaded) and 2003 (clear)......

Figure 16. Bar graph showing geometric mean (and range and sample size) of lead $(\mathrm{Pb})$ concentrations (micrograms per gram, dry weight $[\mu \mathrm{g} / \mathrm{g}, \mathrm{dw}]$ ) in adult bullfrogs (BULL; Lithobates catesbeianus), larval bullfrogs (BFTP), foothill yellow-legged frogs (FYLF; Rana boylii), and Pacific chorus frogs (PACF; Pseudacris regilla) collected from Whiskeytown National Recreation Area and vicinity, northwestern California, 2002 (shaded) and 2003 (clear)

Figure 17. Bar graph showing geometric mean (and range and sample size) of selenium (Se) concentrations (micrograms per gram, dry weight $[\mu \mathrm{g} / \mathrm{g}, \mathrm{dw}]$ ) in adult bullfrogs (BULL; Lithobates catesbeianus), larval bullfrogs (BFTP), foothill yellow-legged frogs (FYLF; Rana boylii), and Pacific chorus frogs (PACF; Pseudacris regilla) collected from Whiskeytown National Recreation Area and vicinity, northwestern California, 2002 (shaded) and 2003 (clear)......

Figure 18. Bar graph showing geometric mean (and range and sample size) of zinc (Zn) concentrations (micrograms per gram, dry weight $[\mu \mathrm{g} / \mathrm{g}, \mathrm{dw}]$ ) in adult bullfrogs (BULL; Lithobates catesbeianus), larval bullfrogs (BFTP), foothill yellow-legged frogs (FYLF; Rana boylii), and Pacific chorus frogs (PACF; Pseudacris regilla) collected from Whiskeytown National Recreation Area and vicinity, northwestern California, 2002 (shaded) and 2003 (clear) ....

Figure 19. Bar graphs showing geometric mean (and range and sample size) of arsenic (As) concentrations (micrograms per gram, dry weight [ $\mu \mathrm{g} / \mathrm{g}, \mathrm{dw}]$ ) in riffle sculpin (Cottus gulosus), rainbow trout (Oncorhynchus mykiss), and California roach (Hesperoleucus symmetricus) collected from Whiskeytown National Recreation Area and vicinity, northwestern California, 2002 (shaded) and 2003 (clear).....

Figure 20. Bar graphs showing geometric mean (and range and sample size) of cadmium ( $\mathrm{Cd}$ ) concentrations (micrograms per gram, dry weight $[\mu \mathrm{g} / \mathrm{g}, \mathrm{dw}]$ ) in riffle sculpin (Cottus gulosus), rainbow trout (Oncorhynchus mykiss), and California roach (Hesperoleucus symmetricus) collected from Whiskeytown National Recreation Area and vicinity, northwestern California, 2002 (shaded) and 2003 (clear)...... 
Figure 21. Bar graphs showing geometric mean (and range and sample size) of copper ( $\mathrm{Cu}$ ) concentrations (micrograms per gram, dry weight [ $\mathrm{\mu g} / \mathrm{g}, \mathrm{dw}]$ ) in riffle sculpin (Cottus gulosus), rainbow trout (Oncorhynchus mykiss), and California roach (Hesperoleucus symmetricus) collected from Whiskeytown National Recreation Area and vicinity, northwestern California, 2002 (shaded) and 2003 (clear)

Figure 22. Bar graphs showing geometric mean (and range and sample size) of total mercury ( $\mathrm{Hg}_{\mathrm{T}}$ ) concentrations (micrograms per gram, wet weight [ $\mathrm{\mu g} / \mathrm{g}, \mathrm{ww}]$ ) in riffle sculpin (Cottus gulosus), rainbow trout (Oncorhynchus mykiss), and California roach (Hesperoleucus symmetricus) collected from Whiskeytown National Recreation Area and vicinity, northwestern California, 2002 (shaded) and 2003 (clear).

Figure 23. Bar graphs showing geometric mean (and range and sample size) of lead (Pb) concentrations (micrograms per gram, dry weight [ $\mathrm{\mu g} / \mathrm{g}, \mathrm{dw}]$ ) in riffle sculpin (Cottus gulosus), rainbow trout (Oncorhynchus mykiss), and California roach (Hesperoleucus symmetricus) collected from Whiskeytown National Recreation Area and vicinity, northwestern California, 2003.

Figure 24. Bar graphs showing geometric mean (and range and sample size) of selenium (Se) concentrations (micrograms per gram, dry weight [ $\mathrm{\mu g} / \mathrm{g}, \mathrm{dw}]$ ) in riffle sculpin (Cottus gulosus), rainbow trout (Oncorhynchus mykiss), and California roach (Hesperoleucus symmetricus) collected from Whiskeytown National Recreation Area and vicinity, northwestern California, 2002 (shaded) and 2003 (clear)...

Figure 25. Bar graphs showing geometric mean (and range and sample size) of zinc $(\mathrm{Zn})$ concentrations (micrograms per gram, dry weight $[\mu \mathrm{g} / \mathrm{g}, \mathrm{dw}]$ ) in riffle sculpin (Cottus gulosus), rainbow trout (Oncorhynchus mykiss), and California roach (Hesperoleucus symmetricus) collected from Whiskeytown National Recreation Area and vicinity, northwestern California, 2002 (shaded) and 2003 (clear)..

\section{Tables}

Table 1. Sampling sites, locations (NAD 83), sampling dates, and biological samples collected for metals and trace elements analyses in Whiskeytown National Recreation Area and nearby Clear Creek watershed, northwestern California, 2002-03

Table 2. Community parameters calculated for samples collected from sites in the Whiskeytown National Recreation Area and nearby Clear Creek watershed, northwestern California, 2002.

Table 3. Summary of quality assurance/quality control results from Trace Element Research Laboratory, for samples collected from Whiskeytown National Recreation Area and nearby Clear Creek watershed, northwestern California, 2002-03.

Table 4. Sample reach lengths and selected habitat characteristics of sites sampled in Whiskeytown National Recreation Area and nearby Clear Creek watershed, northwestern California, 2002-03

Table 5. Relative contamination by critical elements in invertebrates at sites sampled in Whiskeytown National Recreation Area and nearby Clear Creek watershed, northwestern California, 2002-03

Table 6. Relative contamination by critical elements in fish at sites sampled in Whiskeytown National Recreation Area and nearby Clear Creek watershed, northwestern California, 2002-03 


\section{Conversion Factors}

Inch/Pound to International System of Units

\begin{tabular}{|c|c|c|}
\hline Multiply & By & To obtain \\
\hline \multicolumn{3}{|c|}{ Length } \\
\hline inch (in.) & 2.54 & centimeter $(\mathrm{cm})$ \\
\hline foot (ft) & 0.3048 & meter $(\mathrm{m})$ \\
\hline \multicolumn{3}{|c|}{ Area } \\
\hline square foot $\left(\mathrm{ft}^{2}\right)$ & 0.09290 & square meter $\left(\mathrm{m}^{2}\right)$ \\
\hline \multicolumn{3}{|c|}{ International System of Units to Inch/Pound } \\
\hline Multiply & By & To obtain \\
\hline \multicolumn{3}{|c|}{ Length } \\
\hline millimeter (mm) & 0.0394 & inch (in) \\
\hline meter $(\mathrm{m})$ & 3.281 & foot $(\mathrm{ft})$ \\
\hline kilometer $(\mathrm{km})$ & 0.621 & mile (mi) \\
\hline \multicolumn{3}{|c|}{ Area } \\
\hline square meter $\left(\mathrm{m}^{2}\right)$ & 0.000247 & acre \\
\hline hectare (ha) & 2.471 & acre \\
\hline \multicolumn{3}{|c|}{ Volume } \\
\hline milliliter (mL) & 0.061 & cubic inch $\left(\mathrm{in}^{2}\right)$ \\
\hline liter (L) & 61.025 & cubic inch $\left(\mathrm{in}^{3}\right)$ \\
\hline liter (L) & 0.264 & gallon (gal) \\
\hline cubic meter $\left(\mathrm{m}^{3}\right)$ & 264.2 & gallon (gal) \\
\hline cubic meter $\left(\mathrm{m}^{3}\right)$ & 35.31 & cubic foot $\left(\mathrm{ft}^{3}\right)$ \\
\hline \multicolumn{3}{|c|}{ Flow rate } \\
\hline cubic meter per second $\left(\mathrm{m}^{3} / \mathrm{s}\right)$ & 35.31 & cubic foot per second $\left(\mathrm{ft}^{3} / \mathrm{s}\right)$ \\
\hline liter per second $(\mathrm{L} / \mathrm{s})$ & 0.0353 & cubic foot per second \\
\hline \multicolumn{3}{|c|}{ Mass } \\
\hline nanogram (ng) & 0.0000000000353 & ounce, avoirdupois (oz) \\
\hline microgram $(\mu \mathrm{g})$ & 0.0000000353 & ounce, avoirdupois (oz) \\
\hline milligram (mg) & 0.0000353 & ounce, avoirdupois (oz) \\
\hline $\operatorname{gram}(\mathrm{g})$ & 0.3527 & ounce, avoirdupois (oz) \\
\hline
\end{tabular}

Temperature in degrees Celsius $\left({ }^{\circ} \mathrm{C}\right)$ may be converted to degrees Fahrenheit $\left({ }^{\circ} \mathrm{F}\right)$ as follows:

${ }^{\circ} \mathrm{F}=\left(1.8 \times^{\circ} \mathrm{C}\right)+32$ 


\section{Datum}

Horizontal coordinate information is referenced to the North American Datum of 1983 (NAD 83).

\section{Supplemental Information}

Concentrations of chemical constituents in water are given in milligrams per liter ( $\mathrm{mg} / \mathrm{L}$, parts per million), micrograms per liter ( $\mu \mathrm{g} / \mathrm{L}$, parts per billion), or nanograms per liter (ng/L, parts per trillion). Concentrations of chemical constituents in sediment are given in micrograms per gram ( $\mu \mathrm{g} / \mathrm{g}$, parts per million) or nanograms per gram $(\mathrm{ng} / \mathrm{g}$, parts per billion). Concentrations of chemical constituents in tissues are given in micrograms per gram ( $\mu \mathrm{g} / \mathrm{g}$, parts per million).

\section{Abbreviations}

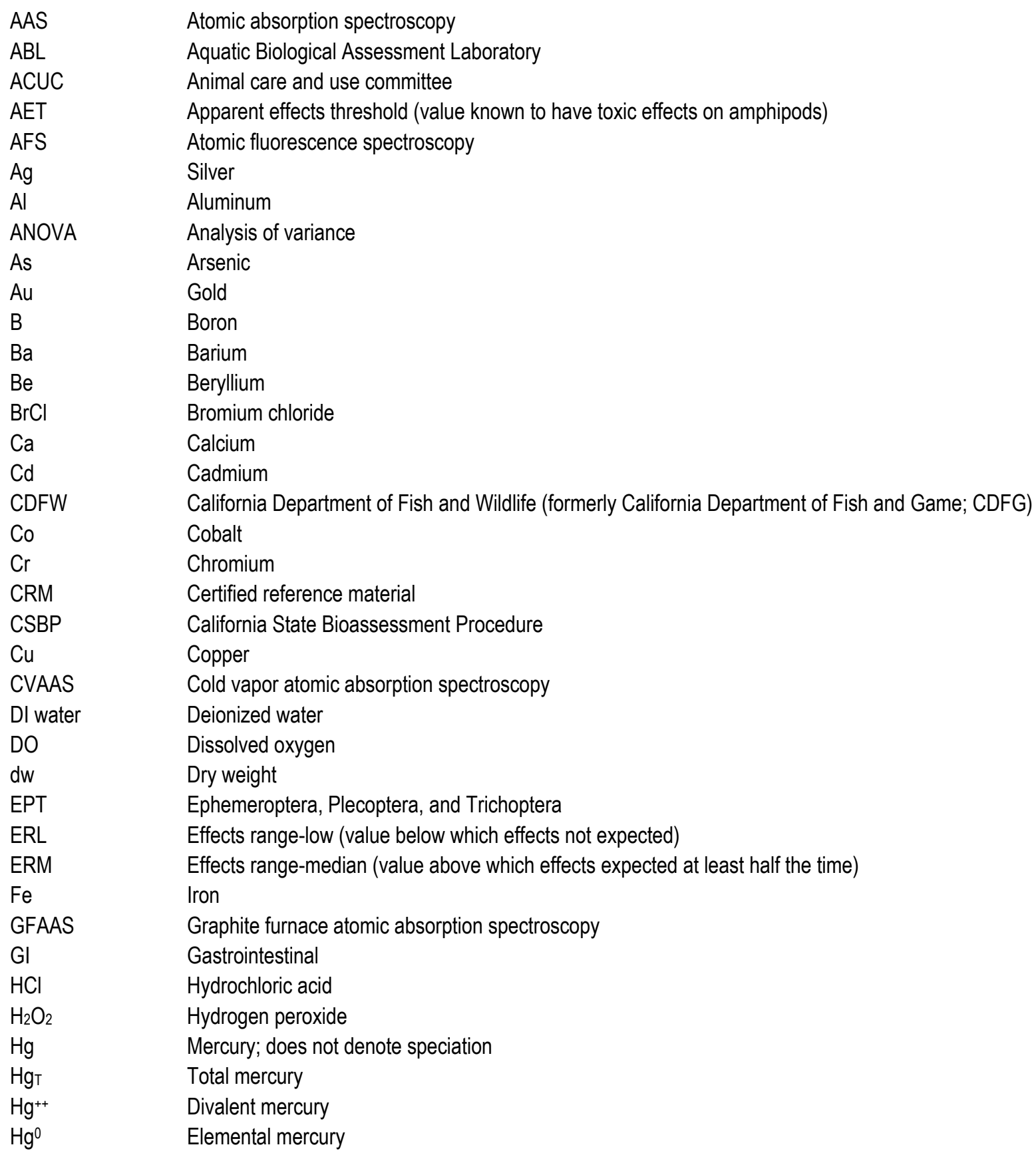




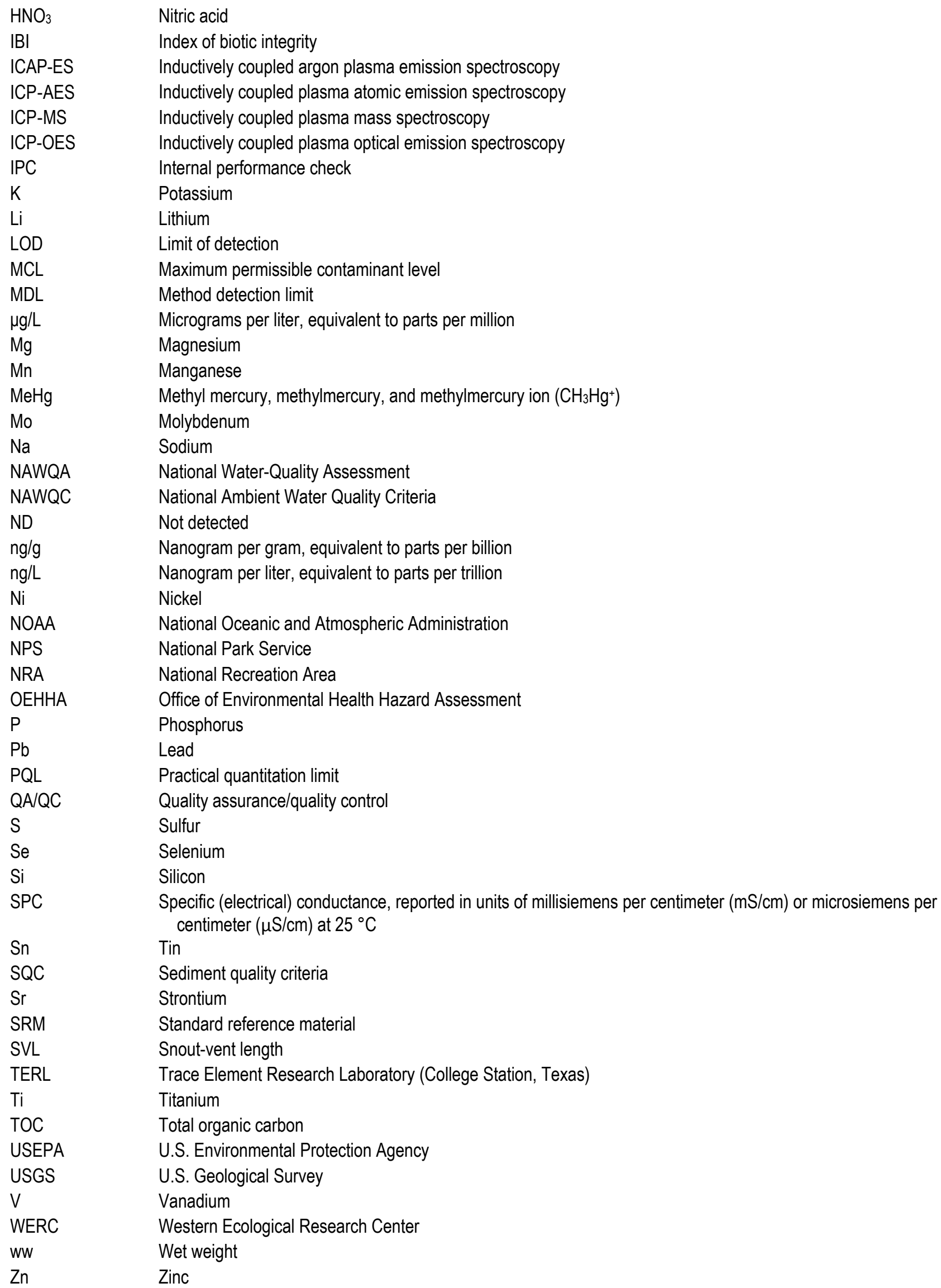


This page left intentionally blank 


\title{
Concentrations of Metals and Trace Elements in Aquatic Biota Associated with Abandoned Mine Lands in the Whiskeytown National Recreation Area and nearby Clear Creek Watershed, Shasta County, Northwestern California, 2002-2003
}

\author{
By Roger L. Hothem¹, Jason T. May¹, Jennifer K. Gibson², and Brianne E. Brussee ${ }^{1}$
}

\begin{abstract}
Park management of the Whiskeytown National Recreation Area, in northwestern California, identified a critical need to determine if mercury $(\mathrm{Hg})$ or other elements originating from abandoned mines within the Upper Clear Creek watershed were present at concentrations that might adversely affect aquatic biota living within the park. During 2002-03, the U.S. Geological Survey, in cooperation with the National Park Service, collected aquatic invertebrates, amphibians, and fish, and analyzed them for $\mathrm{Hg}$, cadmium, zinc, copper, and other metals and trace elements. The data from the biota, in conjunction with data from concurrent community bioassessments, habitat analyses, water quality, and concentrations of metals and trace elements in water and sediment, were used to identify contamination "hot spots."
\end{abstract}

In 2002, we selected collection sites within the study area based on the presence of historical mines and results from sampling of bed sediment in 2001. In 2003, collection sites were selected based on sediment data as well as data on water and biota from this study in 2002. Eleven sites were sampled in both 2002 and 2003, 11 sites were sampled only in 2002, and 14 sites were sampled only in 2003.

Comparisons of sites within the Upper Clear Creek watershed indicated that most of the more contaminated sites were outside of the park boundaries, especially at sites within the French Gulch, Cline Gulch, and Whiskey Creek watersheds. The site with the highest overall contamination within the park, based on both fish and invertebrate data, was WLCC, a site on Willow Creek impacted by acid mine drainage and listed as impaired under Section 303(d) of the Clean Water Act.

Compared with other recently evaluated mine-impacted watersheds in northern California, invertebrates, amphibians, and fish from sites within the Upper Clear Creek watershed tended to have significantly lower concentrations of $\mathrm{Hg}$ than at most other sites. For other metals and trace elements, Upper Clear Creek sites were only compared with the Deer Creek watershed, Nevada County, California. Copper from both Willow Creek sites (WLCC and WLTH) in the Clear Creek watershed was the only metal with concentrations in biota that were significantly higher than biota from Deer Creek.

${ }^{1}$ U.S. Geological Survey.

${ }^{2}$ National Park Service. 


\section{Introduction}

\section{Background}

Whiskeytown National Recreation Area (NRA), managed by the National Park Service (NPS) and established in 1965, is located within the Clear Creek watershed in the Klamath Mountains of northwestern California (fig. 1). The 1,296-ha (3,200-acre) Whiskeytown Lake and its surrounding parklands provide recreation for 700,000 visitors annually. The lake serves as the domestic water supply for the nearby communities of Redding, Shasta, Centerville, Keswick, and Happy Valley, and is one of several lakes that store water for the Central Valley Project.

Mining in Shasta County followed the typical pattern of mining in the Western United States, with boom and bust cycles attendant on discovery, technological developments (including placer gold recovery by panning, ground sluicing, hydraulic mining, dredging, and hard rock mining), and economic and political factors. The periods of heaviest activity included the early 1850 s, following the discovery of gold, the early 20th century (about 1900-14), the 1930s to World War II, and post-World War II. Although the first and last periods are typical of mining in the region, the early 20th-century boom was tied to the development of copper $(\mathrm{Cu})$ mining in the region and contributed to the greatest period of mining prosperity in Shasta County (Lydon and O'Brien, 1974). Today, both hard rock and placer mining continue intermittently in the region.

Mining in the Upper Clear Creek watershed (fig. 1) ranged from placer gold mining to hard rock mining during 1850-1975 and included mining of other commodities, including base metals, granite, and talc during 1896-1960 (Toogood, 1978). Historical data also indicate the presence of 77 gold mines and more than 19 gold-processing facilities within the boundaries of Whiskeytown NRA (the park) (fig. 1). The Mount Shasta Mine on Orofino Creek (sampling sites OCCT, OCSM, and OCAC; see table 1) and the El Dorado Mine on Mill Creek (MCUS and MCDS) were two of the gold mines known to have used mercury $(\mathrm{Hg})$ as a part of the amalgamation process, but it is assumed that $\mathrm{Hg}$ was commonly used at most gold mine sites throughout the park during the $1800 \mathrm{~s}$. Gold mines or claims identified within park subwatersheds include 2 in Mill Creek (MCUS and MCDS), 3 in Grizzly Gulch (GRZL), 2 in New York Gulch (NYGL), 2 in Red Gulch (REDG), 3 in Whiskey Creek (WCWL, WCMM, and WCUM), 2 in White Rock and Foster Gulch (FSGL), and 37 in Orofino Gulch ( OCCT, OCSM, and OCAC ). Remnants of mining include dredge tailing piles, pits, adits, and tunnels.

Historical mines located outside the park boundary are other potentially significant sources of contamination that may affect aquatic life within the park. These mines are present in such watersheds as Mad Ox Gulch (sample sites MDOX, MOXO, and MXUS), Mad Mule Gulch (MMGL), Cline Gulch (CLN1, CLN2, and AMER) and French Gulch (SCRP, RFRG, and FRGL) (R. Weatherbee, NPS, oral commun., 2001). The development of the French Gulch mining district led to discovery of lode gold. Gold was discovered at the Washington Mine in 1852, and this mine, operating intermittently into the 21 st century, has been one of the highest producers in Shasta County (Clark, 1970). Following discovery of gold at the Washington Mine, a complex of hard-rock mines was developed in French Gulch, that included the Franklin, Niagra, Highland (Hightower), Sybil, Brunswick, Niagra Summit, St. Jude, Philadelphia, Summit, and Tom Green mines. 
The Greenhorn Mine, located upstream of the park, is an abandoned $\mathrm{Cu}$, gold (Au), and silver (Ag) mine that discharges acid mine drainage, including cadmium $(\mathrm{Cd})$, iron $(\mathrm{Fe}), \mathrm{Cu}$, and zinc $(\mathrm{Zn})$, into Willow Creek (sampling sites WLCC and WLTH) (California Department of Water Resources, 1985). Concentrations of acid mine drainage, primarily dissolved $\mathrm{Cu}$ and $\mathrm{Zn}$, are sufficiently elevated that they are potentially toxic to aquatic life in Willow Creek from the Greenhorn Mine downstream to the confluence with Crystal Creek. Therefore, according to the Final California 2010 Integrated Report (303(d) List/305(b) Report), Willow Creek has been listed as impaired under Section 303(d) of the Clean Water Act (http://www.waterboards.ca.gov/water_issues/programs/tmdl/2010state_ir_reports/ 01229.shtml, accessed February 4, 2015).

Park management identified a critical need to determine the potential contamination of park aquatic habitats by $\mathrm{Hg}, \mathrm{Cd}, \mathrm{Zn}, \mathrm{Cu}$, and other metals and trace elements from abandoned mines within and upstream of the park. Metals present at elevated concentrations in a water body or its sediment, under conditions that favor the conversion of such metals to organometallic forms, may accumulate in biota causing adverse effects for the animals or their predators. However, concentrations of these elements in water or sediments alone may be poor predictors of the resulting concentrations in biota, thereby making them poor predictors of ecological risk (Wayland and Crosley, 2006).

Mercury, especially in the methylated form (methylmercury; $\mathrm{MeHg}$ ), which can bioaccumulate in invertebrates, amphibians, fish, birds, and other wildlife, is a contaminant of great concern within the park. Elevated $\mathrm{Hg}$ concentrations have been reported for some fish, especially piscivorous species such as largemouth bass (Micropterus salmoides), in streams and reservoirs affected by past hydraulic mining in the Sierra Nevada (Slotton and others, 1995; May and others, 2000), from the nearby Trinity River watershed (May and others, 2005), and from Whiskeytown Lake (May and others, 2012). Human exposure to $\mathrm{MeHg}$, a potent neurotoxin, is almost entirely owing to the consumption of contaminated fish, with developing human fetuses at highest risk (White and others, 1995; Davidson and others, 1998). For these reasons, elevated concentrations of $\mathrm{MeHg}$ in fish have prompted the California Office of Environmental Health Hazard Assessment (OEHHA) to issue Safe Eating Guidelines for Fish Consumption (California Environmental Protection Agency, 2013) for many bodies of water in northern California. In addition to the risk to humans, elevated concentrations of $\mathrm{MeHg}$ in fish also may represent a hazard to fish-eating birds and mammals (Wolfe and others, 1998).

Many aquatic invertebrates inhabit fine-grained sediments, allochthonous materials, or detritus, and ingest these items for food. If these materials are contaminated, they may act as sources of metals to the invertebrates, with even low concentrations resulting in bioaccumulation (Gillespie and Scott, 1971). Aquatic macroinvertebrates are often important components in the diets of fish, amphibians, reptiles, and some riparian birds, and may serve as critical links for metals bioaccumulation. Factors affecting the bioaccumulation of metals in fish include piscivorous feeding habits, food-web biomagnification, fish age and longevity, and water quality (Wiener and Spry, 1996). Upper trophic-level predators, such as the largemouth bass, usually have greater body burdens of $\mathrm{Hg}$ than lower trophic-level species (Neumann and Ward, 1999). Because invertebrates are a critical link in the food web, concentrations of metals in invertebrate tissues have often been used as indicators of bioaccumulation in experimental (Saouter and others, 1993) and field studies (Cain and others, 1992; Axtmann and others, 1997).

Additionally, communities of aquatic macroinvertebrates may be diverse, with individual species inhabiting a body of water from a few months to several years. Macroinvertebrate community structure can indicate the effects of physical and chemical perturbations over time (Merritt and Cummins, 1995; Karr and Chu, 1999). For example, exposure of macroinvertebrate communities to low $\mathrm{pH}$ waters and metals can cause distinct changes in community structure (Lancaster and others, 1996). Biological communities reflect chronic or episodic effects of environmental quality on a scale that varies with the length of the life cycles of the organisms assessed and provide a measure of integrated response. 
Traditional water-quality monitoring designs typically do not capture these effects, nor do they provide for a measure of integrated response (Karr, 1981).

Bioassessments integrate the effects of water and habitat quality over time to evaluate the overall "health" of a watershed. Because organisms from different trophic levels respond to environmental contamination in different ways, an analysis of multiple trophic levels provides a more complete picture (Barbour and others, 1999; Karr and Chu, 1999). Such assessments generally have focused on fish (for example, Karr, 1981; Fausch and others, 1984; Hughes and Gammon, 1987; Barbour and others, 1999), benthic macroinvertebrates (for example, Fore and others, 1996; Barbour and others, 1999), or benthic algae (for example, Pan and others, 1996; Barbour and others, 1999). Fish communities generally integrate conditions at the scale of a year or more, benthic macroinvertebrate communities at the scale of months to a year, and algae at the scale of several weeks.

There is evidence that populations of some amphibians, especially in the Western United States, are declining or have disappeared (Blaustein and others, 1994; Jennings and Hayes, 1994). Because amphibians are known to be especially sensitive to metals, with both teratogenic and lethal effects having been documented (Dial, 1976), metal contamination may have a role in some of these population declines.

In June 2000, park personnel observed a widespread die-off of American bullfrog (Lithobates catesbeianus) tadpoles in Whiskey Creek, a tributary to Whiskeytown Lake. Because they often bioaccumulate metals and other contaminants, larval amphibians may be useful indicators of ecosystem contamination (Cooke, 1981). Therefore, in response to the die-off, the park requested that the U.S. Geological Survey (USGS) include Whiskeytown NRA and the Upper Clear Creek watershed in their ongoing research on abandoned mine lands in northern California. Park personnel were concerned that $\mathrm{Hg}$ or other metals might have contributed to the deaths of the tadpoles. Additionally, park management needed to know if $\mathrm{Hg}$ and other metals originating from abandoned mines within or outside the park were present at concentrations that might adversely affect amphibians or other biota living within the park. The data from this study, indicating concentrations of $\mathrm{Hg}$ and other metals in macroinvertebrates, amphibians, and fish from the Upper Clear Creek watershed and Whiskeytown NRA, were used to determine the presence of contamination "hot spots" that might be candidates for remediation.

\section{Objectives}

The goal of this study, in conjunction with concurrent studies of water quality and concentrations of metals and trace elements in water and sediment, was to evaluate metal and trace element contamination in aquatic biota of Whiskeytown NRA and the Upper Clear Creek watershed. Such information could be used in the selection of potential remediation sites and to enable evaluation of the effects of any future remediation on the environment. Specific objectives were:

1. Collect baseline data on the occurrence and distribution of metals and trace elements in biota, parameters of the benthic macroinvertebrate community, and stream habitat quality from Whiskeytown NRA and upstream sources in the Upper Clear Creek watershed; and

2. Based on baseline data, identify and characterize any "hot spots" for metals contamination within or upstream of the park. 


\section{Study Area and Methods}

\section{Study Area}

The focus for this study is the Whiskeytown NRA, located in the Upper Clear Creek watershed, Shasta County, about $13 \mathrm{~km}$ northwest of Redding, California (fig. 1). In 2002, we selected collection sites within the study area based on the presence of historical mines and results from sampling of bed sediment in 2001 (Moore, 2002). In 2003, collection sites were selected based on bed sediment data (Moore, 2002) as well as data on water and biota from 2002 (first year of this study). Brandy Creek was selected as a potential reference site based primarily on the relative lack of abandoned mines in the watershed. Only the Australia Mine, a small-production gold mine active prior to 1914, is known to have existed in the Brandy Creek watershed (Lydon and O'Brien, 1974). Eleven sites were sampled in both 2002 and 2003, 11 were sampled only in 2002, and 14 were sampled only in 2003 (table 1; fig. 1).

\section{Field Procedures}

\section{Habitat Characterization}

We collected in-stream habitat measurements once at each site in either 2002 or 2003 according to a modified version of the National Water-Quality Assessment (NAWQA) Program stream habitat protocol (Fitzpatrick and others, 1998). Reach lengths of sampled streams were either $80 \mathrm{~m}$ for smaller streams or $200 \mathrm{~m}$ for sites on the four larger streams (BRAN, CCAR, PLTR, and CCCG; see table 1 and fig. 1 for site descriptions, acronyms, and locations). We measured habitat variables, including reach length (in meters), discharge (in cubic meters per second), mean depth (in meters), mean dominant substrate, percent riffle, mean width (in meters), and mean open canopy (in degrees), at each site. Stream width (wetted channel) was measured directly from a transect tape, open canopy was measured from midstream with a clinometer, and canopy cover was calculated using a densitometer. Percentage area of habitat features, such as woody debris and overhanging vegetation, was visually estimated within a section of the transect $2 \mathrm{~m}$ upstream and downstream of the transect tape. At a minimum of three points on each transect, depth was measured with a wading rod, velocity was measured with a Marsh-McBirney Flo-Mate ${ }^{\text {TM }}$ Portable Velocity Flow Meter (Hach Company, Loveland, CO), and the dominant substrate composition was estimated visually. Habitat variables were analyzed as the arithmetic mean of either the transect values or the point values.

\section{Community Assessments}

An adaptation of the California State Bioassessment Procedure (CSBP; Harrington, 1999) was used to assess the biological condition of the streams in the study area. Benthic macroinvertebrates were collected for community analyses from each of 19 study sites to evaluate the biological integrity of each site (table 2). Because of budget constraints, bioassessments were only conducted in 2002. Additionally, although the CSBP method traditionally includes collection of three replicate samples from riffles within a sampling reach, only one composite sample, consisting of individual organisms from three $1-\mathrm{ft}^{2}$ $\left(0.093 \mathrm{~m}^{2}\right)$ locations along a transect, was collected per site. Benthic macroinvertebrates were collected by placing a D-shaped, 500- $\mu \mathrm{m}$ mesh net on the substrate and disturbing an area as wide as the net and 1 $\mathrm{ft}(0.305 \mathrm{~m})$ upstream. The $1-\mathrm{ft}^{2}$ area was excavated to a depth of about $4-6 \mathrm{in}$. $(10.2-15.2 \mathrm{~cm})$ by kicking or using a tool to loosen the substrate. Large rocks were scrubbed by hand under water in front of the net. After a consistent sampling effort at each area, the three collections were combined to make one composite sample that was then rinsed in a standard size 35 sieve $(0.5 \mathrm{~mm}$ mesh). The sampled material was placed in a jar that was then completely filled with 95 percent ethanol. The California 
Department of Fish and Wildlife (CDFW) Aquatic Biological Assessment Laboratory (ABL) in Chico, California, processed samples based on the U.S. Environmental Protection Agency (USEPA)-approved 300-organism fixed-count method. The ABL classified organisms to the lowest practical taxon, usually genus for well-known groups, or sometimes a higher taxonomic group for lesser-known, difficult-toidentify groups

To assess the stream biological condition at the sampled stream sites, we calculated scores for each site using the northern California index of biotic integrity (IBI) (Rehn and others, 2005). The IBI is composed of a set of metrics that together represent different attributes of assemblage composition, structure, and function such as species richness, tolerance guilds, and trophic guilds. Metrics were included based on their responsiveness to anthropogenic stressor gradients or their ability to discriminate between reference sites and sites suspected to have been exposed to anthropogenic stressors.

The metrics included in the IBI were the number of EPT (Ephemeroptera, Plecoptera, and Trichoptera) taxa, the number of Coleoptera taxa, the number of Diptera taxa, the percentage of intolerant individuals, the percentage of non-insect taxa, the percentage of predator taxa, the percentage of non-gastropod scrapers, and the percentage of shredder taxa. Andrew Rehn (CDFW) calculated the metric scores from the raw count data using a standard spreadsheet for calculation of IBI scores for the State of California. The IBI scoring range is divided into five equal categories as follows: $0-20=$ "very poor," 21-40="poor," 41-60="fair," 61-80="good," and 81-100="very good."

\section{Water}

General water-quality parameters, including discharge (in cubic meters per second), specific conductance (SPC, in microsiemens per centimeter), $\mathrm{pH}$, alkalinity, water temperature, and dissolved oxygen (DO), were measured at ungaged sites using electronic meters by Brian Rasmussen of Whiskeytown NRA. Water temperature and DO measurements were made in-place.

Water samples, collected by Brian Rasmussen (Whiskeytown NRA) using a mid-stream grab method, were analyzed for major ions and selected trace metals at the USGS Columbia Environmental Research Center (Columbia, MO) in 2002 and at the Murdock Environmental Geochemistry Laboratory at the University of Montana (Missoula, MT) in 2003. Elements included in the analyses were aluminum (Al), arsenic (As), barium (Ba), beryllium $(\mathrm{Be})$, calcium $(\mathrm{Ca}), \mathrm{Cd}$, cobalt $(\mathrm{Co})$, chromium $(\mathrm{Cr}), \mathrm{Cu}, \mathrm{Fe}, \mathrm{Hg}$, potassium $(\mathrm{K})$, lithium (Li), magnesium $(\mathrm{Mg})$, manganese (Mn), molybdenum (Mo), sodium $(\mathrm{Na})$, nickel $(\mathrm{Ni})$, phosphorus $(\mathrm{P})$, lead $(\mathrm{Pb})$, sulfur $(\mathrm{S})$, selenium $(\mathrm{Se})$, silicon $(\mathrm{Si})$, tin $(\mathrm{Sn})$, strontium (Sr), titanium (Ti), vanadium (V), and Zn.

\section{Sediment}

Sediment samples collected in conjunction with this study were analyzed for metals and total organic carbon (TOC) by J.N. Moore of the University of Montana (Moore, 2002; Moore and Hughes, 2003). Samples were collected using USGS NAWQA protocols (Shelton and Capel, 1994), were placed on ice and frozen, and were shipped to the Murdock Environmental Geochemistry Laboratory at the University of Montana for chemical analyses. See Moore (2002) and Moore and Hughes (2003) for further details.

\section{Biota}

Collections of all vertebrate biota during this study were in accordance with criteria listed in the Animal Care and Use Committee (ACUC) plan approved by the Western Ecological Research Center (WERC) ACUC chair and Center Director. 


\section{Invertebrates}

The target aquatic macroinvertebrates for elemental analysis in this study were predatory insects, depending on their abundance and availability at each sample site. Taxa collected were larval dragonflies (Odonata: Gomphidae, Libellulidae, Aeshnidae, and Cordulegastridae), adult water striders (Hemiptera: Gerridae), larval stoneflies (Plecoptera: Perlidae), larval dobsonflies (Megaloptera: Corydalidae), and adult predaceous diving beetles (Coleoptera: Dytiscidae). Banana slugs (Gastropoda: Arionidae) also were collected at a limited number of sites. Invertebrates were collected using dip nets and by hand and placed in ZipLoc ${ }^{\circledR}$ plastic bags with native water. When possible, we collected replicate samples, multiple size classes within a taxon, or both in order to assess variability in concentrations and to identify any relationships of tissue concentrations with size. Labeled, bagged samples were stored in a cooler on wet ice and allowed to depurate for 4-24 hours before they were processed. In the laboratory, individuals were sorted by family and placed in clean disposable dishes using Teflon ${ }^{\circledR}$-coated forceps or by hand while wearing disposable latex gloves. Organisms were thoroughly rinsed with deionized (DI) water and blotted dry with a clean paper towel. Individual composite samples, consisting of 1-30 individuals of the same family, and with a minimum wet biomass of $1 \mathrm{~g}$, were placed in chemically cleaned glass jars with Teflon ${ }^{\circledR}$-lined lids. The sample mass $( \pm 0.01 \mathrm{~g})$ was determined using an electronic balance, and the jars were sealed with Parafilm ${ }^{\circledR}$. Samples were stored frozen and were shipped within 30 days of collection to the laboratory for analysis for Al, As, boron (B), Ba, Be, Ca, Cd, Co, Cr, Cu, Fe, Hg, K, Mg, Mn, Mo, Na, Ni, P, Pb, S, Se, Sr, Ti, V, and $\mathrm{Zn}$.

During the first year of the study, 97 composite samples were analyzed, representing 1-7 taxa from each of the 22 study sites. In the second year, 1-6 taxa were analyzed from each of 25 sites, totaling 140 composite samples.

\section{Amphibians}

One to four adult amphibians of each species, as available, were collected at each site by hand, or using nets, seines, or electrofishing equipment. The collection priority for amphibians was American bullfrogs (bullfrogs) first, followed by Pacific chorus frogs (Pseudacris regilla) (chorus frogs), and foothill yellow-legged frogs (Rana boylii) (yellow-legged frogs) as a final option. In 2002, bullfrog tadpoles also were collected from WCWL, a site near the location of the earlier tadpole die-off. Samples were placed in a cooler containing dry ice. Animal contact with the dry ice was avoided to prevent freezing (Andrews and others, 1993). Once the frogs were rendered unconscious or dead from the carbon dioxide, they were stored frozen on dry ice or in a freezer until they could be processed.

In the laboratory, the snout-vent length (SVL) for each specimen was determined with calipers $( \pm 0.1 \mathrm{~mm})$; the whole-body mass $( \pm 0.01 \mathrm{~g})$ was determined using an electronic balance; and, where possible, age and sex were determined. For each specimen, the gastrointestinal (GI) tract was removed and thoroughly flushed with DI water. It was then combined with the appropriate carcass, the total sample mass $( \pm 0.01 \mathrm{~g})$ was determined, and the combined sample was stored frozen in a chemically cleaned jar with a Teflon ${ }^{\circledR}$-lined lid sealed with Parafilm ${ }^{\circledR}$, pending chemical analysis within 30 days. In 2002, at least one individual from one of the three species was collected at 9 of the 22 sites. In 2003, at least one individual from one of the three species was collected from 10 of the 25 sites. Each sample was analyzed for Al, As, B, Ba, Be, Ca, Cd, Co, Cr, Cu, Fe, Hg, K, Mg, Mn, Mo, Na, Ni, P, Pb, S, Se, $\mathrm{Si}, \mathrm{Sr}, \mathrm{Ti}$, and $\mathrm{Zn}$. 
The fish species collected at the most sites (15 sites in 2002, and 16 sites in 2003) was riffle sculpin (Cottus gulosus). The riffle sculpin is a small (57-119 mm, total length) resident fish with a high level of site fidelity that feeds mainly on benthic insects, including mayflies (Ephemeroptera) and webspinning caddisflies (Trichoptera: Hydropsychidae) (Baltz and others, 1982). Small rainbow trout (Oncorhynchus mykiss) (45-215 mm, total length) were collected at 13 sites in 2002 and 8 sites in 2003. The smaller trout ( $<180 \mathrm{~mm}$, total length) feed on various immature aquatic invertebrates, including midges (Diptera: Chironomidae) and black flies (Diptera: Simuliidae), and mayflies (Ephemeroptera: Baetidae), as well as terrestrial and winged insects (Tippets and Moyle, 1978). The larger trout (180$215 \mathrm{~mm}$, total length) also feed on caddisflies (Trichoptera: Limnophilidae). California roach (Hesperoleucus symmetricus), which feed on larval mayflies and damselflies (Odonata: Zygoptera), filamentous algae, and diatoms (Power, 1992), were collected at four sites in 2002 and eight sites in 2003 as supplemental fish indicators, especially where sculpin were not abundant. For each species, similar sizes were collected at each site as much as possible, using backpack electrofishing with a Smith-Root Type XII electrofisher (Smith-Root, 14014 NE Salmon Creek Avenue, Vancouver, Washington 98686). Captured fish were held in native water in buckets and were then euthanized by asphyxiation in a cooler with dry ice. In the laboratory, the standard and total lengths $( \pm 0.1 \mathrm{~mm})$ of each fish were determined using a fish board, and its total mass $( \pm 0.01 \mathrm{~g})$ was determined on an electronic balance. Each fish was then wrapped in aluminum foil and was placed in a labeled polyethylene ZipLoc ${ }^{\circledR}$ bag. Samples were stored frozen until processing. Within 30 days, each fish was thawed and examined for gross deformities, dissected to determine sex, and cleaned to remove the contents of the GI tract. Samples were processed according to procedures described by May and others (2000). Each whole-body sample, including the empty GI tract, was thoroughly rinsed with DI water, placed in an individual chemically clean glass sample jar with a Teflon ${ }^{\circledR}$-lined lid sealed with Parafilm ${ }^{\circledR}$, and stored frozen for no more than 30 days before samples were sent to the laboratory for analysis. Five samples from each site, in addition to replicates for quality assurance, were analyzed for $\mathrm{Al}, \mathrm{As}, \mathrm{B}, \mathrm{Ba}, \mathrm{Be}, \mathrm{Ca}$, $\mathrm{Cd}, \mathrm{Co}, \mathrm{Cr}, \mathrm{Cu}, \mathrm{Fe}, \mathrm{Hg}, \mathrm{K}, \mathrm{Mg}, \mathrm{Mn}, \mathrm{Mo}, \mathrm{Na}, \mathrm{Ni}, \mathrm{P}, \mathrm{Pb}, \mathrm{S}, \mathrm{Se}, \mathrm{Si}, \mathrm{Sr}, \mathrm{Ti}, \mathrm{V}$, and Zn.

\section{Laboratory Methods}

\section{Water}

Mercury analysis was conducted, after an in-bottle oxidation step with bromium chloride $(\mathrm{BrCl})$ reagent, with a Teledyne Leeman Labs, Inc.(6 Wentworth Drive, Hudson, New Hampshire 03051) Model Hydra atomic fluorescence (AF) $\mathrm{Hg}$ analyzer following USEPA Method 245.7 (U.S. Environmental Protection Agency, 2005). Results from the analysis of standard solutions suggested a practical quantitation limit (PQL; lowest level at which a value can be reported, with reasonable confidence, at \pm 30 percent of true value) for our analytical method of $2.5 \mathrm{ng} / \mathrm{L}$ or slightly lower. All 2.5 $\mathrm{ng} / \mathrm{L}$ standards analyzed as unknowns before and after the sample runs were returned between 2.1 and $3.0 \mathrm{ng} / \mathrm{L}$ (approximately \pm 20 percent of true value). Trace element analyses were conducted using the inductively coupled plasma atomic emission spectrometry (ICP-AES) technique on a Thermo Elemental Model IRIS) equipped with a CETAC Model U-5000AT+ ultrasonic nebulizer (USEPA Method 200.15) (U.S. Environmental Protection Agency, 1994a). 
Sediment

Digested sediment samples were analyzed for selected elements including $\mathrm{As}, \mathrm{Cd}, \mathrm{Cr}, \mathrm{Cu}, \mathrm{Hg}$, $\mathrm{Pb}$, and $\mathrm{Zn}$ using inductively coupled argon plasma emission spectroscopy (ICAP-ES) (USEPA Method 200.7) (U.S. Environmental Protection Agency, 1994b). Mercury was analyzed using atomic fluorescence spectrometry (AFS) (USEPA Method 245.7) (U.S. Environmental Protection Agency, 2005). Selenium was analyzed by hydride generation atomic absorption spectrometry (AAS). See Moore (2002) and Moore and Hughes (2003) for further details.

Biota

Biological samples were sent by Federal Express ${ }^{\circledR}$ frozen on dry ice within 30 days of collection to the Trace Element Research Laboratory (TERL), College Station, Texas, and were assigned unique identification numbers. Tissue samples were transferred to labeled, tared polyethylene ZipLoc ${ }^{\circledR}$ bags, weighed, and lyophilized in a Labconco ${ }^{\circledR}$ Freezone 12L freeze dryer. Moisture content was determined by weight loss following freeze-drying.

Tissue samples were prepared for analysis by powdering freeze-dried tissue in a Spex 6800 cryomill (65 Liberty Street, Metuchen, New Jersey 08840). Samples were transferred to polycarbonate containers, chilled to liquid nitrogen temperatures, and ground to a fine powder with a stainless steel impacter. Aliquots of dry, powdered tissue samples were weighed to the nearest $0.0001 \mathrm{~g}$ and transferred to polypropylene digestion vessels. Samples were digested at a temperature of $95{ }^{\circ} \mathrm{C}$ with nitric acid $\left(\mathrm{HNO}_{3}\right)$ and hydrochloric acid $(\mathrm{HCl})$, and hydrogen peroxide $\left(\mathrm{H}_{2} \mathrm{O}_{2}\right)(3,1$, and $2 \mathrm{~mL}$, respectively) in a CPI (http://www.cpiinternational.com/) graphite block digester. Digest solutions were made to volume with Milli-Q 18 Megaohm DI water and were stored in polyethylene bottles until analyzed.

In 2002 and 2003, biological samples were analyzed for $\mathrm{Al}, \mathrm{As}, \mathrm{B}, \mathrm{Ba}, \mathrm{Be}, \mathrm{Ca}, \mathrm{Cd}, \mathrm{Co}, \mathrm{Cr}, \mathrm{Cu}$, Fe, Hg, K, Mg, Mn, Mo, Na, Ni, P, Pb, S, Se, Si, Sr, Ti, V, and Zn, with the following exceptions: In 2002, fish and frogs were not analyzed for Mo, and invertebrates were not analyzed for K and Si. In 2003, no sample was analyzed for Si. Additionally, fish were not analyzed for $\mathrm{Na}, \mathrm{P}$, and S; frogs were not analyzed for $\mathrm{S}$ and $\mathrm{Ti}$; most invertebrates were not analyzed for $\mathrm{K}$ and $\mathrm{P}$; and no sample was analyzed for $\mathrm{Ti}$. However, certain invertebrates collected in 2003 were analyzed for $\mathrm{K}$ and $\mathrm{P}$, but not for S.

Mercury was determined in samples by cold vapor atomic absorption spectroscopy (CVAAS) using a CETAC 7500 QuickTrace instrument (CETAC Technologies, 14306 Industrial Road, Omaha, Nebraska 68144) equipped with a heated absorption cell and thermostatically stabilized detector block. Divalent $\mathrm{Hg}\left(\mathrm{Hg}^{++}\right)$in tissue digests was reduced to the elemental state $\left(\mathrm{Hg}^{0}\right)$ with stannous chloride, and the resulting $\mathrm{Hg}^{0}$ vapor was measured in an atomic absorption cell. The amount of $\mathrm{Hg}$ in the sample was determined by comparing light absorption of the sample with that of calibration standards.

Inductively coupled plasma mass spectroscopy (ICP-MS) was used to determine $\mathrm{As}, \mathrm{Cd}$, and $\mathrm{Pb}$ in all samples from 2003, and invertebrate samples from 2002. Tissue digests were diluted with Milli-Q 18 Megaohm DI water as necessary to reduce their nitric acid concentrations to no greater than 2 percent by volume. They were then analyzed in pulse mode on a PerkinElmerSCIEX ${ }^{\mathrm{TM}}$ DRC 2 ICP-MS instrument equipped with a dynamic reaction cell to eliminate molecular ion interferences on several elements (for example, As, Se, Cr, and V). Elemental concentrations were determined using internal standards to compensate for slight matrix effects and instrumental performance changes. 
For fish and frog samples from 2002, $\mathrm{As}, \mathrm{Cd}$, and $\mathrm{Pb}$ were determined by graphite furnace atomic absorption spectroscopy (GFAAS). We also used GFAAS to determine the Cd concentration in select invertebrate and fish samples from 2003. GFAAS uses electrical resistance heating to evaporate solvent (water), remove interfering elemental species, and finally atomize the analyte into the light path of an atomic absorption spectrophotometer. The method is subject to numerous chemical and physical interferences, and requires the use of matrix modifiers to produce accurate and reliable data in realworld sediment, tissue, and water digest solutions.

Inductively coupled plasma-optical emission spectroscopy (ICP-OES) was used to determine $\mathrm{Al}$, $\mathrm{B}, \mathrm{Ba}, \mathrm{Be}, \mathrm{Ca}, \mathrm{Co}, \mathrm{Cr}, \mathrm{Cu}, \mathrm{Fe}, \mathrm{K}, \mathrm{Mg}, \mathrm{Mn}, \mathrm{Mo}, \mathrm{Ni}, \mathrm{P}, \mathrm{S}, \mathrm{Si}, \mathrm{Sr}, \mathrm{Ti}, \mathrm{V}$, and $\mathrm{Zn}$ in samples where those elements were analyzed. Digest solutions were analyzed undiluted on an axial SPECTRO (Kleve, Germany) CirOs instrument, using internal standards to compensate for matrix effects and instrument drift. Final calculations used off-peak background correction and inter-element correction equations. AFS was used to determine Se concentrations in all samples.

\section{Quality Assurance/Quality Control (QA/QC)}

\section{Water}

For $\mathrm{Hg}$, external check standards $(30 \mathrm{ng} / \mathrm{L})$ were analyzed before and after each set of 10 samples and were within 10 percent of the true value. Analytical blanks were analyzed at the same frequency and were less than detectable levels $(<\mathrm{PQL})$. Six samples were analyzed in duplicate or quadruplicate. Two duplicates were consistently less than PQL. Three other duplicates were all between 2.5 and $5 \mathrm{ng} / \mathrm{L}$ and varied by 1,4 , and 52 percent, respectively. The only sample analyzed in quadruplicate was measured once at $8 \mathrm{ng} / \mathrm{L}$ and three times at less than the PQL. These data suggest that analytical results for unknown samples may not be as precise as the analysis of standards, and outliers are possible, most likely because of slight, but significant, sample contamination either in the sample bottles or in the preparation process. Five samples were spiked with $20 \mathrm{ng} / \mathrm{L} \mathrm{Hg}$. Spike recoveries ranged between 96 and 116 percent.

For trace elements, blank samples and independent check standards (internal performance check, or IPC) were analyzed before and after each set of 10 samples. Elements were mostly undetectable in the blanks, and IPC values were within 10 percent of the reported values. The only two exceptions were the IPCs for Na and Sn, where the measured values were 88-91 percent and 86-91 percent of the true concentration, respectively. Six samples were analyzed in duplicate, with all detectable results within 10 percent of each other, except for one sample where Mn concentrations varied by 13 percent. This variability was expected because of the low Mn concentration $(0.0015 \mathrm{mg} / \mathrm{L})$ near the PQL. Five samples were spiked with a mixed standard of known concentrations. All spike recoveries were within 10 percent of the nominal value, except for the recovery of sulfur in one spike, where the recovery was 21 percent more than the nominal value.

\section{Sediment}

See Moore (2002) and Moore and Hughes (2003) for details regarding QA/QC for sediment. 
Biota

All standard environmental laboratory and field procedures for QA/QC were followed for this study (U.S. Fish and Wildlife Service, 1997). Calibration on all instruments used a blank and at least three calibration standards that bracketed the measured sample concentrations. Instrument response was evaluated immediately following calibration and thereafter following every 10 samples and at the end of the analytical run by running a check standard and a check blank. Laboratory quality-control samples went through digestion and analytical steps, and included method blanks, certified reference materials (CRMs), duplicate samples, and spiked samples with each analytical batch of 20 or fewer samples. Analyses of blanks, spikes, duplicates, and standard reference materials (SRMs) were performed, and all were acceptable (table 3 ).

\section{Data Analyses}

\section{Taxonomic Comparisons}

We used Analysis of variance (ANOVA) to describe the significance of year, order, family, watershed, and site on metals concentrations in invertebrates. For fish and amphibians, we used ANOVA to describe the significance of year, species, watershed, and site on metal concentrations. Statistical analyses were restricted to the nine elements considered most likely to have adverse effects on biota: $\mathrm{Hg}, \mathrm{As}, \mathrm{Cd}, \mathrm{Cr}, \mathrm{Cu}, \mathrm{Ni}, \mathrm{Pb}, \mathrm{Se}$, and $\mathrm{Zn}$, and ANOVAs were conducted separately by animal type (fish, frogs, and invertebrates) for each element.

For any metal that was not detected (ND=less than the limit of detection [LOD]) in at least one sample in any animal group, frequency tables were created to determine the frequencies of nondetectable concentrations by animal group. Any element-animal group combination with $>50$ percent non-detects was not analyzed. For element-animal groups with $<50$ percent non-detects, the non-detect values were replaced for the analyses by 50 percent of the minimum detection limit. Based on the $50-$ percent rule, ANOVAs were conducted for $\mathrm{Hg}, \mathrm{As}, \mathrm{Cd}, \mathrm{Cu}, \mathrm{Se}$, and $\mathrm{Zn}$ for fish. For amphibians, additional $\mathrm{ANOVAs}$ were conducted for $\mathrm{Cr}$ and $\mathrm{Pb}$. However, the $\mathrm{Cd}$ data for fish and frogs were too sparse to model year effects, and in the case of fish, were too sparse to model species effects. For invertebrates, ANOVAs were conducted for all nine metals.

Based on preliminary ANOVAs on fish, there was some evidence for interactions, but there were insufficient data to fully test for all potential interactions. Additionally, different interactions emerged for different elements, so that although a certain interaction effect (such as year*species) would be disposable and even inestimable for certain elements, it appeared to be significant for one of the other elements. Because it is difficult to determine whether a lack of statistical interaction is owing to a lack of interaction or a lack of data to detect that interaction, these mixed results are complex and challenging to interpret and are beyond the scope of this report. Therefore, we chose to present the ANOVAs based on main effects only (that is, no interactions), aware that certain interaction effects might be present that cannot be fully explored with these data. 
To examine and compare the levels of each factor in the model (for example, years, order, family, watershed, and site), we used SAS statistical software (SAS Institute Inc., 2010) to calculate model-based means. These means also are known as least squares means, which are mean logtransformed concentrations that the model predicts for balanced sampling conditions (that is, evenly distributed samples across all watersheds, orders, families, years, and sites within watersheds). We used t-statistics to test the difference between each pair of factor levels at the 0.05 significance level, and we present predicted concentration estimates by back-transforming the model-based means and their 95percent confidence intervals. We used the delta method to calculate standard errors of the backtransformed model-based means (Williams and others, 2002).

\section{Site/Watershed Comparisons}

For invertebrates, for each year, we determined each site-metal geometric mean concentration by first calculating the geometric mean for each taxon collected at that site and then calculating the geometric mean for all taxa from that site. For fish, for each year, we determined each site-metal geometric mean concentration by first calculating the geometric mean for each species collected at that site and then calculating the geometric mean for all species from that site. However, too few fish had detectable concentrations of $\mathrm{Cr}, \mathrm{Ni}$, and $\mathrm{Pb}$ in 2002 and $\mathrm{Cr}$ and $\mathrm{Ni}$ in 2003 to include them in the analyses.

For metals with sample values less than the detection limit, 50 percent of the LOD was used to calculate the geometric mean concentration for that site. If metal concentrations in more than 50 percent of the samples from a site were less than the LOD, it was determined that that metal was not detected (ND) at that site.

For each site/metal combination, we calculated the geometric mean of all invertebrates analyzed for that metal at that site. We normalized concentration data using a median value for each metal to allow comparison of the relative degree of contamination at the various sampling sites. The median for each metal among the various sites was then computed by year using the geometric mean corresponding to each site for which data were available. Ranking in the ranking charts (tables 5 and 6) represent the ratio of the geometric mean of concentration values for a given metal at a given site to the median value for that metal at all sites. However, numbers in the charts are geometric means of all invertebrates collected at that site. To compare different metals among sites, these ratios were split into three categories, presented in different colors. For each metal, values less than the median were considered low. Values greater than or equal to the median but less than twice the median were considered medium. Values two or more times the median were considered high. Overall ranking of sites, which estimated the relative level of contamination per site, per year, and per taxon, was determined based on individual element rankings at each site, with the least contaminated sites at the top and the most contaminated sites at the bottom (tables 5 and 6 ). 


\section{Results and Discussion}

\section{Habitat}

In-stream habitat measurements were collected once for 31 of 36 total study sites (table 4). Five sites that were unsuitable for this type of assessment were two ponds (MLPD1 and MLPD2), a mine tunnel outlet (MOXO), a small pond beneath a waterfall (SLCR), and a main-stem Clear Creek site that was too hazardous to access (CDOC). As expected, the six sites on the main stem of Clear Creek (CCCG, FGCP, H299, FGTP, CCAR, and PLTR) had greater discharge, were deeper and wider, and, generally, had less canopy cover than the other sites. The substrate scores at the main-stem sites ranged from 5 (coarse gravel) to 6 (very coarse gravel) (table 4), whereas the substrate scores at the tributary sites ranged from 4.3 (fine/medium gravel) at OCAC to 8.8 (between large cobble and small boulder) at GRZL. Additional data for some of these sites collected during studies in 2004-05 are presented in a report by Wulff and others (2012).

\section{Community Assessments}

Invertebrate community samples were collected at 19 stream sites in 2002 (table 2). The three sites with the lowest IBI scores were from Orofino Creek (OCSM, OCAC, and OCCT), likely related to the fact that these sites also had the lowest discharge rates of all sites assessed. Orofino Creek downstream of the lower stamp mill (OCSM) had the lowest EPT richness, percent non-insect taxa, and percent predator taxa (table 2). Additionally, OCSM had the second-lowest Coleoptera richness and percent non-Gastropoda scrapers. As a result, the condition of OCSM was ranked "poor," with the lowest IBI score of all the sites assessed in 2002. Sites on Orofino Creek were not assessed during 2003 or during studies conducted in 2004-05 (Wulff and others, 2012).

Although several sites - including Willow Creek (WLCC), French Gulch (FRGL), and both sites on Whiskey Creek (WCMM and WCWL) - were rated "good" based on their IBI scores, concentrations of various metals and other trace elements were elevated in invertebrates at these sites (see appendix 1). Although WLCC was rated "good" based on its IBI ranking, this reach of Willow Creek has been classified as impaired under Section 303(d) of the Clean Water Act. Additionally, Willow Creek (WLCC) was rated "poor" in 2004 based on its low IBI in a study conducted by Brown and others (2012). Additional data on community assessments conducted again in 2004-05 at many of the same sites assessed in this study are presented in a report by Wulff and others (2012).

\section{Water}

See appendix 2 for water-quality parameters for sites sampled in 2002 and 2003. Differences among water-quality parameters at the 10 sites sampled during both years were likely influenced by the average collection date ( 2 weeks later in 2002 than in 2003) and the amount of precipitation in the previous year (41.4 cm more in 2003 than in 2002). Compared to 2002, discharge and DO were higher in 2003, whereas water temperature, specific conductance, and alkalinity were lower in 2003. Although $\mathrm{pH}$ varied within site, the average for the 10 sites was not different between years.

Raw and filtered water samples were collected in 2002 and 2003 (appendix 3). The highest concentration of As was in a raw sample collected from SCRP in $2003(59.5 \mu \mathrm{g} / \mathrm{L})$. SCRP also had the highest concentration of As of sites sampled in the study by Wulff and others (2012). One filtered sample from OCCT, collected in 2002, had the highest concentration of Cd $(1.50 \mu \mathrm{g} / \mathrm{L}), \mathrm{Ni}(6.1 \mu \mathrm{g} / \mathrm{L})$, and the only detectable concentration of $\mathrm{Pb}(8.7 \mu \mathrm{g} / \mathrm{L})$. The highest concentration of $\mathrm{Cr}$ was in one raw sample from PLTR in $2002(1.8 \mu \mathrm{g} / \mathrm{L})$. All Cr levels were less than the detection limit in samples collected in 2003. The highest Se concentration was in a raw sample from WCMM in $2002(0.70 \mu \mathrm{g} / \mathrm{L})$; 
Se was not analyzed in 2003. The two raw samples collected from WLCC in 2002 had the highest and second-highest concentrations of both $\mathrm{Cu}(140.0$ and $120.0 \mu \mathrm{g} / \mathrm{L})$ and $\mathrm{Zn}$ (both with concentrations of $190 \mu \mathrm{g} / \mathrm{L})$. Both the $\mathrm{Cu}$ and $\mathrm{Zn}$ concentrations exceeded the National Ambient Water Quality Criteria (NAWQC) acute criteria for the two metals $(18.0 \mu \mathrm{g} / \mathrm{L}$ and $120 \mu \mathrm{g} / \mathrm{L}$, respectively) (Suter and Tsao, 1996). The two raw samples collected from WLTH in 2002 also had $\mathrm{Cu}$ concentrations (both with concentrations of $27.0 \mu \mathrm{g} / \mathrm{L}$ ) that exceeded the NAWQC acute criteria for $\mathrm{Cu}$. The two filtered samples from WLCC had $\mathrm{Cu}$ concentrations $(15.0$ and $17.0 \mu \mathrm{g} / \mathrm{L})$ that exceeded the NAWQC chronic criteria for $\mathrm{Cu}(12.0 \mu \mathrm{g} / \mathrm{L})$ (appendix 3) (Suter and Tsao, 1996). Willow Creek also had the highest concentrations of $\mathrm{Cu}$ and $\mathrm{Zn}$ in 2004-05 (Wulff and others, 2012).

None of the measured aqueous $\mathrm{Hg}_{\mathrm{T}}$ concentrations exceeded or was even close to the maximum permissible contaminant levels (MCLs) set by the USEPA for drinking water $(2 \mu \mathrm{g} / \mathrm{L})$ (U.S.

Environmental Protection Agency, 2011) (appendix 3). The highest concentration in one of the analyzed water samples was $0.0251 \mu \mathrm{g} / \mathrm{L}(25.1 \mathrm{ng} / \mathrm{L})$ from REDG in 2003, or approximately 100 times lower than the drinking water standard. Additional data for studies conducted in 2004-05 are presented in a report by Wulff and others (2012).

\section{Sediment}

Data for the most likely toxic elements (As, $\mathrm{Cd}, \mathrm{Cr}, \mathrm{Cu}, \mathrm{Hg}, \mathrm{Pb}, \mathrm{Se}$, and $\mathrm{Zn}$ ) (Long and others, 1995) are presented in appendix 4. In 2002, the highest concentrations of As were in sediment collected from CLN1 $(264.0 \mu \mathrm{g} / \mathrm{g})$. These concentrations were about five times higher than the next-highest concentration (H299; $53.8 \mu \mathrm{g} / \mathrm{g}$ ), which were much higher than the effects range-median (ERM) for As $(70 \mu \mathrm{g} / \mathrm{g})$, the value above which effects are expected at least half of the time. The highest concentration of As in samples collected in 2003 was $848.40 \mu \mathrm{g} / \mathrm{g}$ in one sample from AMER, a value about 12 times the ERM for As. SCRP also had elevated concentrations of As in sediment (714.80 $\mu \mathrm{g} / \mathrm{g}$ ) (appendix 4). Overall, As concentrations exceeded the value below which effects are not expected (effects range-low $[E R L]=8.2 \mu \mathrm{g} / \mathrm{g}$ ) and the ERM value more often in 2003 than in 2002 (appendix 4). During 2004-05, the site with the highest concentration of As in the bed sediment was SCRP (440 $\mu \mathrm{g} / \mathrm{g}$ ) (Wulff and others, 2012).

The highest Cd concentrations in 2002-03, as well as in 2004-05 (Wulff and others, 2012), were from the Whiskey Creek watershed. In 2002, the Cd concentration in sediment was $19.20 \mu \mathrm{g} / \mathrm{g}$ at WCMM, a value greater than the ERM for $\mathrm{Cd}(9.6 \mu \mathrm{g} / \mathrm{g})$; the next highest concentration was from MDOX $(9.22 \mu \mathrm{g} / \mathrm{g})$. The highest Cd concentration observed in 2003 was from MXUS (8.88 $\mu \mathrm{g} / \mathrm{g})$. More than half of the samples collected in 2003 had Cd concentrations lower than the detection level, and only 20 percent of the samples exceeded the ERL $(1.2 \mu \mathrm{g} / \mathrm{g})$, compared with 2002 when 62.5 percent of the samples had concentrations higher than the ERL.

The highest $\mathrm{Cr}$ concentrations in 2002 and 2003 were in sediment from NYGL (190.0 and 229.2 $\mu \mathrm{g} / \mathrm{g}$, respectively), both lower than the ERM $(370 \mu \mathrm{g} / \mathrm{g})$ but higher than the ERL $(81 \mu \mathrm{g} / \mathrm{g})$. No sediment $\mathrm{Cr}$ concentration exceeded the ERM in either year, and less than 20 percent of the samples exceeded the ERL in both years.

The highest concentrations of $\mathrm{Cu}$ were in samples from Willow Creek in 2002, the only year that Willow Creek was sampled. Both Willow Creek sites, WLCC (1,071.0 and 1,037.0 $\mu \mathrm{g} / \mathrm{g})$ and WLTH $(651.0 \mu \mathrm{g} / \mathrm{g})$, exceeded the $\mathrm{Cu}$ ERM $(270 \mu \mathrm{g} / \mathrm{g})$. The highest concentration of $\mathrm{Cu}$ in sediment in $2004-$ $05(1,190 \mu \mathrm{g} / \mathrm{L}$ ) also was in Willow Creek (Wulff and others, 2012). The highest Cu concentration observed in sediment in 2003 was $364.80 \mu \mathrm{g} / \mathrm{g}$ from REDG, a tributary to the Whiskey Creek arm of Whiskeytown Lake. Sediment samples collected from all the sites in 2002-03, with the exception of the reference (BRAN), exceeded the ERL for $\mathrm{Cu}(34 \mu \mathrm{g} / \mathrm{g})$, but samples from only four sites (8.7 percent) exceeded the ERM. 
The highest $\mathrm{Hg}_{\mathrm{T}}$ concentration in sediment in 2002 was $1.63 \mu \mathrm{g} / \mathrm{g}$ from MDOX, followed by $0.98 \mu \mathrm{g} / \mathrm{g}$ at CLN1. CLN2 had the highest $\mathrm{Hg}_{\mathrm{T}}$ concentration in sediment in $2003(1.82 \mu \mathrm{g} / \mathrm{g})$, whereas SCRP had the highest concentration in 2004-05 $(2.8 \mu \mathrm{g} / \mathrm{g}$ ) (Wulff and others 2012). Although these three concentrations exceeded the ERM for $\mathrm{Hg}$ in sediment $(0.71 \mu \mathrm{g} / \mathrm{g})$, only two other sites, AMER and CDOC, met or exceeded the ERM in 2003. The ERL $(0.15 \mu \mathrm{g} / \mathrm{g})$ was exceeded at 56 percent of the sites during the 2 years.

The highest $\mathrm{Pb}$ concentrations were in sediment from MDOX $(38.6 \mu \mathrm{g} / \mathrm{g})$ in 2002 , and from $\operatorname{SCRP}(84.4 \mu \mathrm{g} / \mathrm{g})$ in 2003, but neither value was greater than the ERM $(218 \mu \mathrm{g} / \mathrm{g})$. Ten sites had Pb concentrations greater than the ERL $(46.7 \mu \mathrm{g} / \mathrm{g})$ in 2003 , but no samples exceeded that value in 2002. SCRP had the highest concentration of $\mathrm{Pb}$ in sediment $(133 \mu \mathrm{g} / \mathrm{g}$ ) in 2004-05 (Wulff and others, 2012).

Selenium was only analyzed in 2003; the highest concentration was in a sample from Whiskey Creek below Mad Mule Gulch (WCMM; $10.47 \mu \mathrm{g} / \mathrm{g}$ ), which was 10 times higher than the apparent effects threshold (AET; $1.0 \mu \mathrm{g} / \mathrm{g}$ ) (Buchman, 2008). This selenium concentration was about 2.8 times higher than the next highest concentration, also from Whiskey Creek, above both Mad Mule and Mad Ox Gulches (WCUM; $3.72 \mu \mathrm{g} / \mathrm{g}$ ). In 2003, 72 percent of the sites had Se concentrations greater than the AET.

In 2002, the highest concentrations of Zn were from the Whiskey Creek watershed (WCMM, $908 \mu \mathrm{g} / \mathrm{g}$; MDOX, $613 \mu \mathrm{g} / \mathrm{g}$; and WCWL, $506 \mu \mathrm{g} / \mathrm{g})$, but samples from Willow Creek also had elevated levels of Zn (WLCC, $814 \mu \mathrm{g} / \mathrm{g}$ [average of two samples]; and WLTH, $434 \mu \mathrm{g} / \mathrm{g}$ ). In 2003, no samples were collected from Willow Creek, and, as in 2002, the highest concentrations, ranging from 573.6 to 1,575.2 $\mu \mathrm{g} / \mathrm{g}$, were from Whiskey Creek (MXUS, WCUM, MDOX, WCMM, and WCWL). Willow Creek had the highest concentration of $\mathrm{Zn}$ in the sediment $(1,224 \mu \mathrm{g} / \mathrm{g}$ ) in 2004-05 (Wulff and others, 2012). See Moore (2002) and Moore and Hughes (2003) for further details regarding sediment metal concentrations in 2002 and 2003, and Wulff and others (2012) for additional data for studies conducted at Whiskeytown NRA in 2004-05.

\section{Biota}

Biota were collected to improve the predictability of ecological risk at the sites sampled in this study. However, the simultaneous presence of many potentially toxic elements, combined with multiple confounding environmental variables under field conditions, makes it difficult to assess the toxic effects on biota (Borgmann and others, 2007). Therefore, we present individual concentrations of the potentially most toxic elements at collection sites without attempting to evaluate the potential synergistic or antagonistic effects of the elements.

\section{Invertebrates}

Predatory insects were collected in 2002 and 2003 and were analyzed for metals and trace elements (appendix 1). Four taxa (larval dobsonflies, adult water striders, larval dragonflies [family Gomphidae], and larval stoneflies) were collected at most sites during 2002 and 2003 (figs. 2-9).

For the bar graphs shown as figures 2-25, the first site presented in each graph (from left to right on the $\mathrm{x}$-axis) is the reference site on Brandy Creek (BRAN), which flows into Whiskeytown Lake from the south-southwest (fig. 1). The remaining 33 sites are presented generally in an upstream direction, starting with the furthest downstream site on Clear Creek, CDOC. Tributaries with collection sites that flow into Clear Creek or Whiskeytown Lake are presented as they enter Whiskeytown Lake or Clear Creek going in an upstream direction. However, within each tributary, the individual sites are presented starting with those most upstream of the lake or creek. The final site is the one furthest upstream on Clear Creek (CCCG). 
Arsenic concentrations in invertebrates generally were higher from sites sampled in 2002 than from the same sites sampled in 2003 (fig. 2, appendix 1). However, the nine samples with the highest concentrations of As $(>20.0 \mu \mathrm{g} / \mathrm{g}$, dry weight [dw]) were collected in 2003. Seven of these were collected from the French Gulch watershed (RFRG, SCRP, and FRGL), whereas the other two were from the Cline Gulch watershed (CLN1 and AMER); all of these sites were outside the park boundaries. Five of these nine samples were dragonfly larvae (Gomphidae), and three were larval dobsonflies, whereas the highest As concentration $(265 \mu \mathrm{g} / \mathrm{g})$ was in a sample of dragonfly larvae (Cordulegastridae) collected from SCRP (not graphed). Water striders tended to have low concentrations of As, with only one of the 57 strider samples (NYGL, 2002) having concentrations $>4.0 \mu \mathrm{g} / \mathrm{g}$ As. The reference site, Brandy Creek, generally had low concentrations of As in invertebrates.

Invertebrates collected in 2003 generally had higher Cd concentrations than those collected in 2002, with 16 of the 18 highest values recorded that year (fig. 3). Invertebrates collected from sites in the Whiskey Creek watershed or on tributaries to the Whiskey Creek arm of Whiskeytown Lake had 26 of the 29 highest values for $\mathrm{Cd}(>5.80 \mu \mathrm{g} / \mathrm{g}$ ) (appendix 1), and all but seven of those samples were collected in 2003. The highest Cd concentration recorded in this study was in dobsonfly larvae from MXUS in 2002 (mean $13.46 \mu \mathrm{g} / \mathrm{g}$; range 12.4-14.6 $\mu \mathrm{g} / \mathrm{g}$ ), and 13 of the 29 samples with the highest Cd concentrations were larval dobsonflies. Concentrations of $\mathrm{Cd}$ from BRAN, the reference site, were consistently low in all taxa, with 13 of the 16 samples with the lowest $\mathrm{Cd}$ concentrations coming from BRAN.

Chromium concentrations were consistently higher in samples collected in 2002 than those collected in 2003 (fig. 4). However, this was partially explained by a higher LOD (0.191-3.19 $\mu \mathrm{g} / \mathrm{g}$, mean $=0.690 \mu \mathrm{g} / \mathrm{g})$ in 2003 compared with $2002(0.45-1.15 \mu \mathrm{g} / \mathrm{g}$, mean $=0.570 \mu \mathrm{g} / \mathrm{g})$. Chromium was not detected in more than 50 percent of the stonefly samples collected in 2003 (fig. 4). The highest $\mathrm{Cr}$ concentration was in a dobsonfly sample collected from Orofino Creek (OCSM) in $2002(46.5 \mu \mathrm{g} / \mathrm{g})$. The second highest concentration of $\mathrm{Cr}$ was in dragonfly larvae (Aeshnidae) from the reference site, Brandy Creek (appendix 1).

Copper is an element essential to the growth and metabolism of living animals. However, $\mathrm{Cu}$ at high concentrations is one of the most toxic metals to invertebrates (Harding, 2005). The highest concentration of $\mathrm{Cu}(301.0 \mu \mathrm{g} / \mathrm{g})$ was in one 2002 sample of dragonfly (Gomphidae) larvae from WLCC, an area downstream of the Greenhorn Mine, a known source of $\mathrm{Cu}, \mathrm{Zn}$, and acid mine drainage (fig. 5). The second highest concentration of $\mathrm{Cu}(104.0 \mu \mathrm{g} / \mathrm{g})$ in Gomphidae in 2002 also was from Willow Creek (WLTH), just downstream of WLCC.

The highest geometric mean concentrations of $\mathrm{Hg}_{\mathrm{T}}$, on a wet-weight (ww) basis $(0.112,0.092$, and $0.087 \mu \mathrm{g} / \mathrm{g}$ ) in samples of dobsonflies, water striders, and stoneflies, respectively, were from samples collected in 2003 from CLN2 (fig. 6). The second highest concentration of $\mathrm{Hg}_{\mathrm{T}}$ in dragonflies (Gomphidae) also was from CLN2 $(0.110 \mu \mathrm{g} / \mathrm{g})$ in 2003, following the highest concentration in dragonflies collected from MDOX that year $(0.115 \mu \mathrm{g} / \mathrm{g})$. The $\mathrm{Hg}_{\mathrm{T}}$ concentration in dobsonflies from CCCG $(0.089 \mu \mathrm{g} / \mathrm{g})$, the site furthest upstream in the Clear Creek watershed, was similar to that at RFRG and only lower than that from CLN2. Concentrations of $\mathrm{Hg}_{\mathrm{T}}$ in the other three taxa with results graphed were similar to or lower than that at BRAN, the reference site. All the elevated $\mathrm{Hg}_{\mathrm{T}}$ concentrations were from sites outside the park boundaries. 
There were few consistent trends in the concentrations of $\mathrm{Ni}$ in invertebrates, either within or between years. The highest Ni concentrations in larval dragonflies (Gomphidae) in 2002 and 2003 were in samples collected from SLCR (fig. 7, appendix 1). In 2003, samples of dobsonflies from WCUM and SCRP had higher concentrations of Ni than other sites. Nickel concentrations in water striders were generally lower than concentrations for the other three taxa $(<2.0 \mu \mathrm{g} / \mathrm{g})$, with 12 site-year combinations having concentrations less than the LOD (fig. 7, appendix 1). Lower concentrations of Ni in invertebrates from BRAN indicated that this site was a suitable reference.

All invertebrate samples collected from BRAN in 2002 had Pb concentrations less than the LOD $(0.061 \mu \mathrm{g} / \mathrm{g})$ (fig. 8), making it a good reference. Highest mean $\mathrm{Pb}$ concentrations in dobsonflies and dragonflies (Gomphidae) were from the French Gulch watershed during both years, the highest of which were from those samples collected from SCRP in 2003 (3.06 and $3.35 \mu \mathrm{g} / \mathrm{g}$, respectively) (appendix 1). Two sites in the upper Whiskey Creek watershed (MOXO and MDOX) had elevated $\mathrm{Pb}$ concentrations in invertebrates in 2002 or 2003 (appendix 1). The sites with the highest concentrations of Pb were all outside the park boundaries.

Concentrations of Se were consistently lowest in samples from BRAN compared to concentrations in invertebrates from other sites during both years (fig. 9). However, Se concentrations were several times higher at the upstream site, CCCG, than at BRAN. Except for water striders, invertebrate samples were generally higher in Se at the Whiskey Creek and French Gulch sites than at other sites, with some high concentrations also in dobsonflies and dragonflies from GRZL. Selenium concentrations were low in dragonflies from Mill Creek (MCUS and MCDS) and Willow Creek (WLTH and WLCC), and in dobsonflies from the Orofino Creek sites (OCCT, OCSM, and OCAC). Water strider samples had generally lower concentrations of $\operatorname{Se}(<3.0 \mu \mathrm{g} / \mathrm{g})$ than other taxa collected from the same sites (fig. 9).

Zinc, like $\mathrm{Cu}$, is an essential element for normal growth and metabolism, but this element in excess may be toxic. Zinc concentrations were generally twice as high in water strider and stonefly samples as in dobsonfly and dragonfly samples collected from similar sites (fig. 10). Samples collected from BRAN generally contained low Zn concentrations (appendix 1), but the lowest Zn concentration observed in all invertebrates sampled was in water striders collected from CLN1 in $2003(70.8 \mu \mathrm{g} / \mathrm{g})$. The highest concentrations of $\mathrm{Zn}$ in samples of both dobsonflies $(318 \mu \mathrm{g} / \mathrm{g})$ and stoneflies $(505 \mu \mathrm{g} / \mathrm{g})$ were from MXUS in 2003. The nearby WCUM had the highest concentration of $\mathrm{Zn}$ in water striders $(484 \mu \mathrm{g} / \mathrm{g})$ in 2003 , whereas the highest concentration of $\mathrm{Zn}$ in dragonflies $(381 \mu \mathrm{g} / \mathrm{g})$ was in a composite sample from WLCC in 2002.

\section{Amphibians}

Results of the analyses of bullfrogs, chorus frogs, and yellow-legged frogs collected in 2002 and 2003 are presented in appendix 5 and figures 11-18. Unfortunately, relatively few samples of amphibians were collected at many of the sites. Thus, especially for sites with only one sample per species (11 sites), differences among sites should be treated with caution. For As, the highest concentrations were in 2003, with yellow-legged frogs from AMER (mean 3.69 $\mu \mathrm{g} / \mathrm{g}$; range 2.81-4.84 $\mu \mathrm{g} / \mathrm{g}$ ) and CLN1 $(3.05 \mu \mathrm{g} / \mathrm{g}$ ), a site located just downstream of AMER (fig. 11), having the highest concentrations. Arsenic was not detected $(<0.313 \mu \mathrm{g} / \mathrm{g})$ in adult bullfrogs from BRAN in 2002. Although the one yellow-legged frog collected at BRAN in 2003 had the lowest concentration (1.00 $\mu \mathrm{g} / \mathrm{g}$ ) of all adult frogs collected in 2003, that concentration was higher than the concentrations in all the adult frogs collected in 2002. The highest concentration of As in frogs in 2002 was in bullfrog tadpoles from WCWL (mean $1.38 \mu \mathrm{g} / \mathrm{g}$ ), which was about three times higher than the concentration in one juvenile bullfrog collected from that site in $2002(0.452 \mu \mathrm{g} / \mathrm{g})$. 
The adult bullfrog collected from WCWL in 2003 contained higher concentrations of Cd ( 1.87 $\mu \mathrm{g} / \mathrm{g}$ ) (fig. 12), Se (3.97 $\mu \mathrm{g} / \mathrm{g}$ ) (fig. 17), and Zn (246 $\mu \mathrm{g} / \mathrm{g}$ ) (fig. 18) than all the other frogs collected in this study. The geometric mean concentration of Cd in bullfrog tadpoles from WCWL in 2002 (1.59 $\mu \mathrm{g} / \mathrm{g}$ ) was similar to that for the juvenile bullfrog from that site in $2002(1.46 \mu \mathrm{g} / \mathrm{g})$ and the adult from WCWL in $2003(1.87 \mu \mathrm{g} / \mathrm{g})$. An adult bullfrog collected from MMGL in 2003 had the second highest concentrations of Cd (1.71 $\mu \mathrm{g} / \mathrm{g}$ ) (fig. 12), Se (3.54 $\mu \mathrm{g} / \mathrm{g})$ (fig. 17), and $\mathrm{Zn}$ (169 $\mu \mathrm{g} / \mathrm{g}$ ) (fig. 18). The concentration of $\mathrm{Cd}$ in the bullfrog from BRAN collected in $2002(0.212 \mu \mathrm{g} / \mathrm{g})$ was the lowest recorded $\mathrm{Cd}$ concentration of all the bullfrogs for both years. Both yellow-legged frogs and chorus frogs had similar and much lower concentrations of $\mathrm{Cd}$ than the bullfrogs at all sites during both years, with the yellow-legged frog from BRAN in 2003 having the lowest concentration of Cd $(0.049 \mu \mathrm{g} / \mathrm{g})$ of all frogs.

Similar to results for invertebrates, the Cr concentration in the bullfrog collected from BRAN in $2002(2.36 \mu \mathrm{g} / \mathrm{g})$ was among the highest for frogs at all the sites sampled during either year (fig. 13). The concentration of $\mathrm{Cr}$ in a foothill yellow-legged frog from BRAN in $2003(0.498 \mu \mathrm{g} / \mathrm{g})$, however, was not especially elevated. Concentrations of $\mathrm{Cr}$ in bullfrogs from tributaries to the Whiskey Creek Arm of Whiskeytown Lake (LBGL, REDG, WCWL, and MMGL) (fig. 1) were elevated during both years. Concentrations of $\mathrm{Cr}$ in chorus frogs were similar to those in bullfrogs, but were higher than those in yellow-legged frogs, in which Cr was detected in only two of eight frogs in 2002. The chorus frog collected from FSGL in 2002 had the highest concentration of $\mathrm{Cr}(3.15 \mu \mathrm{g} / \mathrm{g})$ of all the frogs collected (fig. 13).

The highest concentrations of $\mathrm{Cu}$ (range 15.8-40.3 $\mu \mathrm{g} / \mathrm{g}$ ) were in bullfrogs collected in 2003 from LBGL, MMGL, WCWL, and REDG (fig. 14), tributaries to the Whiskey Creek Arm of Whiskeytown Lake. However, in 2002, among amphibians, the concentration of $\mathrm{Cu}$ in the bullfrog collected from the reference site (BRAN) $(17.6 \mu \mathrm{g} / \mathrm{g})$ was exceeded only by that in a chorus frog from OCCT $(25.2 \mu \mathrm{g} / \mathrm{g})$. The concentration of $\mathrm{Cu}$ in the bullfrog from BRAN was similar to that in bullfrogs collected in 2003 from other sites, but was higher than concentrations in all yellow-legged frogs during both years. Concentrations of $\mathrm{Cu}$ in chorus frogs were generally lower than in bullfrogs, but they were higher than in yellow-legged frogs.

The lowest total $\mathrm{Hg}\left(\mathrm{Hg}_{\mathrm{T}}\right)$ ww concentration in adult amphibians was in a bullfrog from BRAN $(0.017 \mu \mathrm{g} / \mathrm{g})$ (fig. 15) which was similar to the geometric mean in bullfrog tadpoles from WCWL in $2002(0.017 \mu \mathrm{g} / \mathrm{g})$ (appendix 5). The highest concentrations observed in 2002 were in individual yellowlegged frogs from MCUS $(0.081 \mu \mathrm{g} / \mathrm{g})$ and MCDS $(0.080 \mu \mathrm{g} / \mathrm{g})$ and a chorus frog from MLPD2 $(0.080$ $\mu \mathrm{g} / \mathrm{g})$. In 2003, the highest $\mathrm{Hg}_{\mathrm{T}}$ concentration was $0.074 \mu \mathrm{g} / \mathrm{g}$ in a yellow-legged frog from FGTP.

Concentrations of $\mathrm{Pb}$ in chorus frogs $(0.478-1.48 \mu \mathrm{g} / \mathrm{g})$ were all higher than concentrations observed for bullfrogs and yellow-legged frogs in both 2002 and 2003 (fig. 16, appendix 5). In 2002, all eight yellow-legged frogs had $\mathrm{Pb}$ concentrations that were less than the method detection limits $(0.173$ $\mu \mathrm{g} / \mathrm{g})$. In 2003, Pb was detected in all 10 yellow-legged frogs, but all concentrations $(0.052-0.440 \mu \mathrm{g} / \mathrm{g})$ were lower than concentrations in the two chorus frogs $(0.604-0.614 \mu \mathrm{g} / \mathrm{g})$. At SLCR, the only site with both chorus frogs and yellow-legged frogs during the same year (2003), the chorus frog $\mathrm{Pb}$ concentration was 2.6 times higher than the yellow-legged frog $\mathrm{Pb}$ concentration.

Bullfrogs generally had higher concentrations of Se than the other two frog species (fig. 17), whereas Se concentrations in chorus frogs were lower. At SLCR, the only site with both chorus frogs and yellow-legged frogs during the same year (2003), the Se concentration in the yellow-legged frog was 1.7 times higher. 
Zinc concentrations in bullfrogs and chorus frogs were generally similar, and concentrations in both species were higher than for most yellow-legged frogs (fig. 18). However, the Zn concentration in the yellow-legged frog collected at BRAN in $2003(160 \mu \mathrm{g} / \mathrm{g})$ was higher than the concentrations for the other yellow-legged frogs collected in both years and was similar to the $\mathrm{Zn}$ concentrations seen in the other two species during both years.

\section{Fish}

Results of the analyses of fish collected in 2002 and 2003 are presented in appendix 6 and figures 19-25. One or more species of fish was collected from 27 of the 36 sites included in this study. Riffle sculpin were collected from 22 sites during 1 or more years, rainbow trout were collected from 18 sites, and California roach were collected from 8 sites. All three species were collected from only one site (CLN1), whereas both sculpin and trout were collected from 13 sites. Sculpin and roach were collected from six sites, and trout and roach were collected from one site. Trout were collected alone from four sites, and sculpin were collected alone from three sites. These samples were analyzed for 24 metals and trace elements (appendix 6). Of these elements, we selected eight as the ones most likely to cause harm to fish or their predators: $\mathrm{As}, \mathrm{Cd}, \mathrm{Cr}, \mathrm{Cu}, \mathrm{Hg}, \mathrm{Pb}, \mathrm{Se}$, and $\mathrm{Zn}$ (figs. 19-25). However, $\mathrm{Cr}$ was detected in too few samples to allow meaningful comparisons for either year, and, in 2002, $\mathrm{Pb}$ was not compared because concentrations were less than the LOD in more than 50 percent of the samples (see appendix 6).

Concentrations of As in fish collected in 2003 were 2.5-14.5 times higher than As concentrations in fish collected in 2002 from the same sites (fig. 19). The highest concentrations of As were from rainbow trout and riffle sculpin collected from the French Gulch (RFRG, FRGL and SCRP) and the Cline Gulch (CLN1 and CLN2) watersheds. Arsenic concentrations in sculpin and trout from BRAN and the other sites were comparable in 2002. There were no apparent differences in As concentrations among collection sites for California roach for either year.

Similar to trends observed in both the invertebrate and amphibian data, concentrations of $\mathrm{Cd}$ were highest in sculpin and trout from the Whiskey Creek watershed (WCUM, MDOX, WCMM, and WCWL) during both years (fig. 20). Additionally, Cd in sculpin from WLCC also was elevated in 2002. All trout collected in 2002 and sculpin collected in both years from BRAN had Cd concentrations less than the LOD $(0.05$ and $0.21 \mu \mathrm{g} / \mathrm{g}$, respectively). Roach were not collected from either the Whiskey Creek or the Brandy Creek watersheds, but roach from other sites had low concentrations of $\mathrm{Cd}(<0.5$ $\mu \mathrm{g} / \mathrm{g}$ ) with no apparent trends (fig. 20).

The Greenhorn Mine has been identified as the source of $\mathrm{Cu}$ contamination in Willow Creek (California Department of Water Resources, 1985), and concentrations of $\mathrm{Cu}$ were highest in sculpin and trout from Willow Creek (especially the upstream site, WLCC) (fig. 21). The geometric mean concentration of $\mathrm{Cu}$ in the three composite sculpin samples from WLCC was $27.8 \mu \mathrm{g} / \mathrm{g}$ (range 16.1$46.1 \mu \mathrm{g} / \mathrm{g}$ ), a concentration that was 6-18 times higher than concentrations in sculpin from other sites. The concentration of $\mathrm{Cu}$ in the one trout from WLCC $(13.4 \mu \mathrm{g} / \mathrm{g})$ was 2-5 times higher than in trout from other sites. Roach were not collected from WLCC, and roach collected during both years from other sites had low $\mathrm{Cu}$ concentrations $(<0.5 \mu \mathrm{g} / \mathrm{g})$ that did not differ among sites (fig. 21).

Similar to trends in $\mathrm{Hg}_{\mathrm{T}}$ concentrations seen in results for the amphibians and invertebrates, the highest concentrations of $\mathrm{Hg}_{\mathrm{T}}$ in fish were in sculpin in 2003 from the Cline Gulch sites (CLN1 and CLN2), followed by RFRG in the French Gulch watershed (fig. 22, appendix 6). The highest $\mathrm{Hg}_{\mathrm{T}}$ concentration was measured in sculpin from CLN1 (mean $0.263 \mu \mathrm{g} / \mathrm{g}$; range $0.224-0.309 \mu \mathrm{g} / \mathrm{g}$ ), followed by CLN2 (mean $0.250 \mu \mathrm{g} / \mathrm{g}$; range $0.189-0.361 \mu \mathrm{g} / \mathrm{g}$ ), and then RFRG (mean $0.220 \mu \mathrm{g} / \mathrm{g}$; range $0.186-0.260 \mu \mathrm{g} / \mathrm{g}$ ). The highest concentration of $\mathrm{Hg}_{\mathrm{T}}$ in trout also was from CLN1 in 2003 (mean $0.154 \mu \mathrm{g} / \mathrm{g}$; range $0.123-0.188 \mu \mathrm{g} / \mathrm{g})$, followed by MDOX $(0.123 \mu \mathrm{g} / \mathrm{g}$ ) and then RFRG (mean 0.096 
$\mu \mathrm{g} / \mathrm{g}$; range $0.087-0.118 \mu \mathrm{g} / \mathrm{g}$ ). At the eight sites where California roach were collected, $\mathrm{Hg}_{\mathrm{T}}$ concentrations in roach were highest from NYGL (mean $0.108 \mu \mathrm{g} / \mathrm{g}$; range $0.092-0.122 \mu \mathrm{g} / \mathrm{g}$ ) and GRZL (mean $0.102 \mu \mathrm{g} / \mathrm{g}$; range $0.070-0.149 \mu \mathrm{g} / \mathrm{g}$ ) in 2002, followed by CLN1 in 2003 (mean 0.098 $\mu \mathrm{g} / \mathrm{g}$; range $0.074-0.129 \mu \mathrm{g} / \mathrm{g}$ ). Concentrations of $\mathrm{Hg}_{\mathrm{T}}$ at BRAN were low for sculpin during both years, but the mean concentration for trout from BRAN in 2002 was similar to the mean concentrations at the other sites sampled that year.

More than 50 percent of the fish collected in 2002 had concentrations of $\mathrm{Pb}$ that were less than the LOD, so they were not graphed (fig. 23). In 2003, the highest concentration of $\mathrm{Pb}$ in trout was at $\operatorname{MDOX}(0.401 \mu \mathrm{g} / \mathrm{g})$, a value that was about 4 times higher than sculpin from that site. Sculpin had elevated $\mathrm{Pb}$ concentrations at the French Gulch (RFRG and FRGL) and Cline Gulch (CLN1 and CLN2) sites, and mean concentrations at RFRG, FRGL, and CLN1 were about twice that in sculpin from BRAN. Trout and roach were not collected at BRAN, but two sculpin samples from BRAN in 2003 had $\mathrm{Pb}$ concentrations that were higher than 10 other sites and only lower than 5 sites. Lead concentrations in sculpin and trout were as much as 10 times higher than $\mathrm{Pb}$ concentrations in roach, and the lowest concentration of $\mathrm{Pb}$ occurred in two roach collected from NYGL $(<0.0467 \mu \mathrm{g} / \mathrm{g})$.

The concentrations of Se observed in sculpin and trout (fig. 24 were consistently higher at the Whiskey Creek watershed sites (WCUM, MDOX, WCMM, and WCWL) and at the French Gulch sites (RFRG, FRGL, and SCRP) than those in fish from the other sites. The highest values were in sculpin in 2002 from WCMM (mean 9.37 $\mu \mathrm{g} / \mathrm{g}$; range 9.11-9.82 $\mu \mathrm{g} / \mathrm{g}$ ) and FRGL (mean $8.66 \mu \mathrm{g} / \mathrm{g}$; range 8.11$9.21 \mu \mathrm{g} / \mathrm{g}$ ). Selenium concentrations were lowest at BRAN in both sculpin (both years) and trout (2002). With the exception of GRZL in 2002 (mean $4.17 \mu \mathrm{g} / \mathrm{g}$; range 3.86-4.50 $\mu \mathrm{g} / \mathrm{g}$ ), mean concentrations of Se in roach were similar $(2.21-3.51 \mu \mathrm{g} / \mathrm{g})$ among sites where they were collected, but roach were not collected from those sites that indicated the highest and the lowest concentrations of Se in sculpin and trout.

Concentrations of $\mathrm{Zn}$ in roach were about two to three times higher than concentrations in sculpin and trout from the same sites (fig. 25, appendix 6). The highest mean concentrations of $\mathrm{Zn}$ were in roach collected from NYGL in both 2002 and 2003 (267 and $337 \mu \mathrm{g} / \mathrm{g}$, respectively). Elevated concentrations of $\mathrm{Zn}$ in sculpin collected from WLCC in 2002 (mean $213.4 \mu \mathrm{g} / \mathrm{g}$; range 200-221 $\mu \mathrm{g} / \mathrm{g}$ ) were about four times higher than the mean concentration of $\mathrm{Zn}$ in sculpin collected from BRAN in $2002(55.7 \mu \mathrm{g} / \mathrm{g})$. However, concentrations of $\mathrm{Zn}$ in trout collected in 2002 from WLCC $(93.8 \mu \mathrm{g} / \mathrm{g})$ and BRAN (mean $86.47 \mu \mathrm{g} / \mathrm{g}$, range 82.6-91.8 $\mu \mathrm{g} / \mathrm{g}$ ) were not different from each other. The highest $\mathrm{Zn}$ concentration in trout was from OCSM (mean $185.2 \mu \mathrm{g} / \mathrm{g}$; range $151-219 \mu \mathrm{g} / \mathrm{g}$ ).

\section{Relative Contamination within Upper Clear Creek}

\section{Taxonomic Comparisons}

ANOVA was used to compare taxa within animal groups. For invertebrate orders, there were significant differences for all metals $(\mathrm{P}<0.0001)$. Larval dobsonflies were significantly higher than some or all of the other orders for all contaminants except $\mathrm{Cu}$ and $\mathrm{Zn}$. Dragonflies, diving beetles, and banana slugs were all significantly higher than one or more of the other orders for 5-7 elements. Stoneflies were only higher than at least one other order for one element (Ni). Water striders had higher concentrations of $\mathrm{Cd}$ than three families, higher concentrations of $\mathrm{Cr}$ than two families, and significantly higher concentrations of $\mathrm{Zn}$ than all other families. 
Differences were not observed among the three species of amphibians collected for this study for As, $\mathrm{Cd}, \mathrm{Cr}, \mathrm{Hg}$, or $\mathrm{Zn}(\mathrm{P}>0.16)$. Differences were detected, however, for $\mathrm{Cu}, \mathrm{Pb}$, and $\mathrm{Se}(\mathrm{P}<0.012)$. Foothill yellow-legged frogs had significantly lower concentrations of $\mathrm{Cu}$ than bullfrogs and chorus frogs, which were not different from one another. $\mathrm{Pb}$ was higher in chorus frogs than in the other two species, which were not different from one another. The Se concentration was higher in bullfrogs than in the chorus frogs, but yellow-legged frogs were not different from the other species.

For fish, $\mathrm{Cr}, \mathrm{Ni}$, and $\mathrm{Pb}$ were detected in too few samples in 2002 to include in the analyses. There were no significant differences among the three species for $\mathrm{Cd}(\mathrm{P}>0.05)$. $\mathrm{Cu}$ was present in higher concentrations in the rainbow trout than in either the California roach or the riffle sculpin, which were not different from one another $(\mathrm{P}<0.0001)$. Arsenic $(\mathrm{P}=0.0312)$ and $\mathrm{Hg}_{\mathrm{T}}(\mathrm{P}<0.0001)$ had similar patterns in that sculpin had significantly higher concentrations than trout, but neither sculpin nor trout were different from the roach. Sculpin had higher concentrations of Se than the other two species, which were not different from one another $(\mathrm{P}<0.0001)$. The concentration of $\mathrm{Zn}$ was higher in roach than in both the trout and the sculpin, which were not different from one another $(\mathrm{P}<0.0001)$.

\section{Site/Subwatershed Comparisons}

Based on the nine metals considered most likely to cause adverse effects to biota, the trends in relative contamination of sites were similar for invertebrates (table 5) and fish (table 6), especially for sites sampled in both 2002 and 2003. Amphibians were collected during both years at only three sites, so comparisons were made using ANOVA rather than medians (see section, "Study Area and Methods"). As described in table 1, in 2003, we added 12 sites outside the park boundaries that were suspected of having elevated levels of metals in biota, whereas 11 sites within the park that had mostly low levels of contamination in biota in 2002 were not sampled in 2003. In 2002, the most contaminated sites for invertebrates were FRGL, MDOX, and WCMM, all outside the park boundaries (table 5). In 2003, the eight most contaminated sites also were all located outside the park. For fish, the most contaminated site in 2002 was located outside the park (FRGL), but the next two most contaminated sites, WLCC and WCWL, were within the park boundaries (table 6). In 2003, as with invertebrates, the eight most contaminated sites were outside the park (table 6).

During both years, Brandy Creek (BRAN) ranked lowest in overall contamination in both fish and invertebrates, despite having medium levels of $\mathrm{Cr}$ in invertebrates both years as well as medium levels of As in fish in 2002 and Pb in fish in 2003. Based on the ANOVA model, and compared with the site with the highest concentrations, concentrations were significantly lower $(\mathrm{p}<0.05)$ at Brandy Creek for (1) As, $\mathrm{Hg}$, and Se in amphibians; (2) As, Cd, Cu, $\mathrm{Hg}$, Se, and $\mathrm{Zn}$ in fish; and (3) all metals except $\mathrm{Cr}$ in invertebrates.

Two sites on the main stem of Clear Creek were sampled during both years (CCAR and H299), whereas five main-stem sites were sampled only during one year (CCCG, CDOC, FGCP, FGTP, and PLTR) (table 1). None of these sites was ranked above medium for any of the priority contaminants for either invertebrates (table 5) or fish (table 6). The only elevated elements in frogs at these seven sites were $\mathrm{Hg}$ and Se at both FGTP and FGCP in 2003.

Invertebrates had significantly elevated concentrations of $\mathrm{As}, \mathrm{Hg}, \mathrm{Ni}$, and $\mathrm{Pb}$ in the French Gulch watershed (FRGL in 2002 and 2003, and SCRP and RFRG in 2003), and of Cd, Hg, Ni, Pb, and $\mathrm{Zn}$ at one or more sites in the Whiskey Creek watershed both years. Invertebrates at the Slate Creek site (SLCR) had high concentrations of Ni in both 2002 and 2003. As expected, $\mathrm{Cu}$ and $\mathrm{Zn}$ were significantly elevated in both fish and invertebrates from the Willow Creek watershed (WLCC and WLTH), which was sampled only in 2002. 
Fish had significantly higher concentrations of $\mathrm{As}, \mathrm{Hg}$, and Se at one or more sites in the French Gulch watershed (FRGL, SCRP, and RFRG), and of Cd and Se at one or more sites in the Whiskey Creek watershed (WCWL, WCMM, and WCUM).

Overall, FRGL was ranked highest in contamination in 2002, for fish and invertebrates, and was the second most contaminated site for fish and invertebrates in 2003, a year in which several more contaminated sites were added to the study, including three in Cline Gulch (CLN1, CLN2, and AMER) and two in French Gulch (SCRP and RFRG) (figs. 11 and 27). In both 2002 and 2003, FRGL had relatively high concentrations of As and Se in both fish and invertebrates, and, in 2003, FRGL had high concentrations of $\mathrm{Pb}$ in fish and invertebrates.

SCRP, not sampled in 2002, was the most contaminated site for invertebrates collected in 2003, having the highest concentrations of $\mathrm{As}, \mathrm{Cr}, \mathrm{Ni}$, and $\mathrm{Pb}$ (table 5). CLN2 was the most contaminated site for fish in 2003, having the highest concentrations of both $\mathrm{Hg}$ and $\mathrm{Pb}$ (fig. 27). Although FRGL was the only site that had high concentrations of As in both fish and invertebrates collected in 2002, five sites not sampled in 2002 also had high As concentrations in invertebrates in 2003 (CLN1, CLN2, AMER, RFRG, and SCRP) (table 5). Three Whiskey Creek sites, MDOX, WCUM, and WCMM, had high concentrations of Cd in both fish and invertebrates in 2003; MXUS had the highest concentration of Cd in invertebrates in 2003, but no fish were collected at that site. The only site ranked highly contaminated with Zn was NYGL, which ranked highest in fish in 2003, and second most contaminated in 2002 (table 6). Zn concentrations in invertebrates, however, were generally low at NYGL (table 5).

\section{Inter-Watershed Comparisons}

We have evaluated $\mathrm{Hg}$ contamination in biota from numerous northern California watersheds affected by historical mining, including sites in the Trinity and Sierra Nevada Mountains (May and others, 2000, 2005, 2012; Alpers and others, 2005; C.N. Alpers, USGS, written commun., January 15, 2015) and the Coast Range (Rytuba and others, 2011, 2015). However, besides the Whiskeytown area, the only location in which we have consistently analyzed biota for other metals and trace elements is Deer Creek, Nevada County, California, during 2010-2011 (J.A. Fleck, USGS, written commun., February 3, 2015). Techniques used for the collection and analyses of these samples have been comparable to those used to collect samples in this study.

Invertebrates

During the current study, the highest geometric mean concentrations of $\mathrm{Hg}_{\mathrm{T}}(\mathrm{ww})$, in samples of dobsonflies, water striders, and stoneflies, were $0.112,0.092$, and $0.087 \mu \mathrm{g} / \mathrm{g}$, respectively, all from samples collected in 2003 from CLN2 (fig. 6). The highest mean concentration of $\mathrm{Hg}_{\mathrm{T}}$ in dragonflies (Gomphidae) was from MDOX in $2003(0.115 \mu \mathrm{g} / \mathrm{g})$, with the second highest from CLN2 $(0.110 \mu \mathrm{g} / \mathrm{g})$. All the most elevated $\mathrm{Hg}_{\mathrm{T}}$ concentrations were from sites outside the park boundaries.

Analysis of composite samples of aquatic invertebrates from Harley Gulch, Lake County, California, (Rytuba and others, 2011) collected in 2011 after a cleanup of historic mines upstream, indicated that 7 of 17 sites had water striders with higher concentrations of $\operatorname{Hg}_{\mathrm{T}}(>0.092 \mu \mathrm{g} / \mathrm{g})$ than the highest concentration in the Whiskeytown area, with the highest being $0.163 \mu \mathrm{g} / \mathrm{g}$. Additionally, six of nine composite samples of dragonfly larvae (Libellulidae) from Harley Gulch had concentrations of $\mathrm{Hg}_{\mathrm{T}}$ higher than the highest concentration $(0.12 \mu \mathrm{g} / \mathrm{g})$ measured in Gomphidae from MDOX. The highest concentration in dragonfly larvae from Harley Gulch in 2011 was $0.253 \mu \mathrm{g} / \mathrm{g}$. 
Aquatic invertebrates were collected from the Bear Creek watershed, Colusa County, California, during June and September of 2010 (Rytuba and others, 2015). Samples of biota comparable to those collected from the Whiskeytown area that were analyzed for $\mathrm{Hg}_{\mathrm{T}}$ included larval dragonflies and adult water striders. The site sampled for biota upstream of known mining inputs to Bear Creek (BC2; Rytuba and others, 2015) had $0.12 \mu \mathrm{g} / \mathrm{g}$, ww $\mathrm{Hg}_{\mathrm{T}}$ in water striders, which was similar to the highest concentration in the Whiskeytown area. However, the highest $\mathrm{Hg}_{\mathrm{T}}$ concentration at a downstream site on Bear Creek $(0.72 \mu \mathrm{g} / \mathrm{g})$ was about 6 times greater than the concentration recorded at BC2.

Studies conducted during 1999-2003 by Slotton and others (2004) provided additional $\mathrm{Hg}_{\mathrm{T}}$ data for invertebrates at three sites in the Bear Creek watershed. The average $\mathrm{Hg}_{\mathrm{T}}$ concentrations in aquatic insects were lower at the Upper Bear Creek site $(0.031 \mu \mathrm{g} / \mathrm{g}$ for dragonfly larvae [Libellulidae]) than in Gomphidae from MDOX. However, the $\mathrm{Hg}_{\mathrm{T}}$ concentration at the Middle Bear Creek site $(0.343 \mu \mathrm{g} / \mathrm{g}$ for Libellulidae) was 10 times greater than the concentration measured at the Upper Bear Creek site and 3 times greater than the highest concentration from this Whiskeytown study.

Of the samples of larval dragonflies collected from the Sierra Nevada and Trinity Mountains during 1999-2004 (C.N. Alpers, USGS, written commun., January 15, 2015), the highest concentrations of $\mathrm{Hg}_{\mathrm{T}}$ were in composite samples from the Altoona Mercury Mine area of the East Fork Trinity River. Dragonflies (Aeshnidae) collected in 2001 from the Altoona Mine wetlands had $5.4 \mu \mathrm{g} / \mathrm{g} \mathrm{Hg}(0.28 \mu \mathrm{g} / \mathrm{g}$ $\mathrm{MeHg})$. Alpers and others (2005) reported concentrations of $\mathrm{MeHg}$ in dobsonflies $(0.39 \mu \mathrm{g} / \mathrm{g}), \mathrm{larval}$ stoneflies $\left(0.52 \mu \mathrm{g} / \mathrm{g} \mathrm{MeHg} ; 0.47 \mu \mathrm{g} / \mathrm{g} \mathrm{Hg}_{\mathrm{T}}\right)$, and water striders $(0.53-0.79 \mu \mathrm{g} / \mathrm{g})$ that were many times higher than concentrations in the Whiskeytown area.

The highest $\mathrm{Hg}_{\mathrm{T}}$ concentrations in invertebrates from Deer Creek (J.A. Fleck, USGS, written commun., February 3, 2015) and the Whiskeytown study were similar for dobsonflies $(0.11 \mu \mathrm{g} / \mathrm{g})$, water striders $(0.10 \mu \mathrm{g} / \mathrm{g})$, and stoneflies $(0.08 \mu \mathrm{g} / \mathrm{g})$. Only samples of dragonflies (Gomphidae) from Deer Creek $(0.13-0.27 \mu \mathrm{g} / \mathrm{g})$ had higher $\mathrm{Hg}_{\mathrm{T}}$ concentrations than those from the Whiskeytown area. In addition to $\mathrm{Hg}_{\mathrm{T}}$, aquatic invertebrates collected from the Deer Creek watershed also were analyzed for $\mathrm{As}, \mathrm{Cd}, \mathrm{Cr}, \mathrm{Cu}, \mathrm{Ni}, \mathrm{Pb}$, and $\mathrm{Zn}$. In the Whiskeytown area, As concentrations in invertebrates were generally higher than in those from Deer Creek, and the highest concentrations of As $(21.0-33.0 \mu \mathrm{g} / \mathrm{g}$, $\mathrm{dw}$ ) in dragonflies (Gomphidae) was collected in 2003 from the French Gulch watershed (RFRG, SCRP, and FRGL) and the AMER site in the Cline Gulch watershed (48.7 $\mu \mathrm{g} / \mathrm{g}$ ). By comparison, the highest As concentration in Gomphidae from Deer Creek was $17.9 \mu \mathrm{g} / \mathrm{g}$ (J.A. Fleck, USGS, written commun., February 3, 2015). Concentrations of As in water striders ranged from not detected (ND) (2 samples) to $18.6 \mu \mathrm{g} / \mathrm{g}$ at the Whiskeytown sites, and only 15 of the 51 (29 percent) water strider samples had lower concentrations than the highest concentration from Deer Creek $(0.40 \mu \mathrm{g} / \mathrm{g})$. At Deer Creek, larval crane flies (Diptera: Tipulidae), which were not sampled during the Whiskeytown study, had the highest concentration of As $(30.8 \mu \mathrm{g} / \mathrm{g})$. Arsenic concentrations in stoneflies ranged from 0.44 to 0.86 $\mu \mathrm{g} / \mathrm{g}$ at Deer Creek (J.A. Fleck, USGS, written commun., February 3, 2015), and from 0.56 to $4.38 \mu \mathrm{g} / \mathrm{g}$ at Whiskeytown.

The highest concentrations of $\mathrm{Cd}$ in invertebrates from the Whiskeytown area were from sites in the Whiskey Creek watershed or on tributaries to the Whiskey Creek arm of Whiskeytown Lake, which had 26 of the 29 highest values for $\mathrm{Cd}(>5.80 \mu \mathrm{g} / \mathrm{g})$. The highest Cd concentration was in dobsonfly larvae from MXUS in 2002 (mean $13.46 \mu \mathrm{g} / \mathrm{g}$ ), and 13 of the 29 samples with the highest Cd concentrations were dobsonflies. For comparison, the one sample of dobsonflies from Deer Creek contained $3.96 \mu \mathrm{g} / \mathrm{g}$ Cd (J.A. Fleck, USGS, written commun., February 3, 2015). At Deer Creek, mayflies (Ephemeroptera: Heptageniidae) had the highest concentration of Cd $(27.3 \mu \mathrm{g} / \mathrm{g})$, whereas $\mathrm{Cd}$ concentrations in dragonflies ranged from 0.40 to $5.73 \mu \mathrm{g} / \mathrm{g}$. Concentrations of Cd in dragonfly samples from the Whiskeytown area ranged from 0.14 to $9.9 \mu \mathrm{g} / \mathrm{g}$, and 8 of the 48 samples had higher concentrations than the highest Deer Creek sample. Concentrations of $\mathrm{Cd}$ in water striders from Deer 
Creek $(1.39-11.9 \mu \mathrm{g} / \mathrm{g})$ were similar to those from the Whiskeytown study sites $(0.28-8.4 \mu \mathrm{g} / \mathrm{g})$. Cadmium concentrations in stoneflies from the Whiskeytown area ranged from 0.15 to $5.8 \mu \mathrm{g} / \mathrm{g}$, compared with 1.0 to $2.4 \mu \mathrm{g} / \mathrm{g}$ at Deer Creek.

The highest concentration of $\mathrm{Cr}$ observed in stonefly samples from the Whiskeytown area was $12.7 \mu \mathrm{g} / \mathrm{g}$, but more than half ( 60 percent) of the samples collected in $2003 \mathrm{had} \mathrm{Cr}$ concentrations less than the detection limit. Chromium was detected in all stonefly samples from Deer Creek, but the concentrations ranged from 0.36 to only $1.4 \mu \mathrm{g} / \mathrm{g}$ (J.A. Fleck, USGS, written commun., February 3 , 2015). Although $\mathrm{Cr}$ was not detected in 20 percent of the dobsonfly samples from the Whiskeytown area, the highest concentration $(46.5 \mu \mathrm{g} / \mathrm{g})$ was much higher than the concentration of the Deer Creek sample $(1.5 \mu \mathrm{g} / \mathrm{g})$, and 44 percent of the Whiskeytown samples had higher Cr concentrations than those from Deer Creek. Chromium concentrations in Gomphidae (0.12-27.2 $\mu \mathrm{g} / \mathrm{g})$ from Deer Creek were generally higher than those from the Whiskeytown study (ND-13.7 $\mu \mathrm{g} / \mathrm{g}$ ). Concentrations of Cr were similar in water strider samples from Deer Creek (ND-14.4 $\mu \mathrm{g} / \mathrm{g}$ ) and the Whiskeytown study (ND$11.8 \mu \mathrm{g} / \mathrm{g})$.

The highest concentration of $\mathrm{Cu}(301 \mu \mathrm{g} / \mathrm{g})$ observed in the Whiskeytown study was in a sample of dragonfly (Gomphidae) larvae from Willow Creek (WLCC), an area downstream of the Greenhorn Mine. The range of concentrations of $\mathrm{Cu}$ in Deer Creek dragonflies was 8.1-82.4 $\mu \mathrm{g} / \mathrm{g}$ (J.A. Fleck, USGS, written commun, February 3, 2015). The concentrations of $\mathrm{Cu}$ at Deer Creek also were lower for dobsonflies (17.9 compared to 14.5-72.8 $\mu \mathrm{g} / \mathrm{g}$ at Whiskeytown) and stoneflies (27.0-36.9 compared to $25.5-82.8 \mu \mathrm{g} / \mathrm{g})$, but the ranges for water striders were similar (10.6-57.2 compared to $11.7-62.7 \mu \mathrm{g} / \mathrm{g})$.

$\mathrm{Ni}$ concentrations in dobsonflies, dragonflies, and stoneflies were similar at Whiskeytown and Deer Creek, but concentrations in water striders (ND-9.6 $\mu \mathrm{g} / \mathrm{g}$ ) were higher at Deer Creek than at Whiskeytown.

The highest $\mathrm{Pb}$ concentrations in dobsonflies and dragonflies from the Whiskeytown area were from the French Gulch watershed (3.08 and $3.52 \mu \mathrm{g} / \mathrm{g}$, respectively). The maximum concentrations of $\mathrm{Pb}$ in water striders and stoneflies from the Whiskeytown study were similar $(0.46$ and $0.51 \mu \mathrm{g} / \mathrm{g}$, respectively). Water striders, stoneflies, and dobsonflies had similar concentrations of $\mathrm{Pb}$ at Deer Creek and Whiskeytown, but 13 of 20 (65 percent) Deer Creek dragonfly samples $(0.44-13.3 \mu \mathrm{g} / \mathrm{g})$ had higher $\mathrm{Pb}$ concentrations than samples from Whiskeytown. A larval crane fly sample from Deer Creek had a higher concentration of $\mathrm{Pb}(42.8 \mu \mathrm{g} / \mathrm{g})$ than any other taxon at either site (J.A. Fleck, USGS, written commun., February 3, 2015).

The ranges of $\mathrm{Zn}$ concentrations in water striders, dragonflies, stoneflies, and dobsonflies from the Whiskeytown area and Deer Creek overlapped, but the maximums were generally higher at Whiskeytown. However, two taxa from Deer Creek, dragonflies (Cordulegastridae) and mayflies (Heptageniidae), had higher concentrations of $\mathrm{Zn}(1,060$ and $1,070 \mu \mathrm{g} / \mathrm{g}$, respectively) than all the taxa sampled in the Whiskeytown study.

\section{Amphibians}

No frog collected in either year from the Whiskeytown area had a $\mathrm{Hg}_{\mathrm{T}}$ concentration $>0.081$ $\mu \mathrm{g} / \mathrm{g}$. Most amphibians from other northern California watersheds with a history of gold or $\mathrm{Hg}$ mining have had higher $\mathrm{Hg}_{\mathrm{T}}$ concentrations than those collected from the Whiskeytown area. For example, during 1997-98, the highest values for individual adult anurans collected in the Cache Creek watershed, an area heavily impacted by historic $\mathrm{Hg}$ mining, were $0.59 \mu \mathrm{g} / \mathrm{g}$ for chorus frogs, $1.7 \mu \mathrm{g} / \mathrm{g}$ for yellowlegged frogs, and $2.8 \mu \mathrm{g} / \mathrm{g}$ for bullfrogs (Hothem and others, 2010). 
Most of the 58 chorus frogs collected from the Sierra Nevada Mountains during 1999-2004 were from mine tunnels, with the two highest $\mathrm{Hg}_{\mathrm{T}}$ concentrations $(0.385$ and $0.334 \mu \mathrm{g} / \mathrm{g})$ from samples collected in 1999 from the Polar Star Mine tunnel outlet in the Bear River watershed (Alpers and others, 2005).

Most yellow-legged frogs collected in the watersheds of the Trinity, Bear, and Yuba Rivers during 1999-2004 were from streams. The highest $\mathrm{Hg}_{\mathrm{T}}$ concentrations in yellow-legged frogs were from the Altoona Mercury Mine area in 2000-02 (range 0.23-0.76 $\mu \mathrm{g} / \mathrm{g}$ ) (C.N. Alpers, USGS, written commun., January 15, 2015). Primarily because of a lack of habitat, only 33 bullfrogs were collected in the Sierra Nevada Mountains, mostly from standing water (ponds or lakes). Of these bullfrogs, three of the five with the highest $\mathrm{Hg}_{\mathrm{T}}$ concentrations $(0.181-0.272 \mu \mathrm{g} / \mathrm{g})$ were in samples collected from a mine pond site at Malakoff Diggins in the South Yuba watershed (C.N. Alpers, USGS, written commun., January 15, 2015).

Fish

Black bass (Micropterus spp.) were collected in 2005 (May and others, 2012) to evaluate the concentrations of $\mathrm{Hg}$ and other elements in fish of Whiskeytown Lake. Fish also were collected during 2000-02 in the Trinity River watershed (May and others, 2005), the watershed adjacent and to the west of the Clear Creek watershed, as part of studies of $\mathrm{Hg}$ contamination of historical mine lands. Rainbow trout were collected at most stream sites, and marbled sculpin (Cottus klamathensis) were collected from one site on the East Fork Trinity River. Rainbow trout were collected from the watersheds of the Bear and Yuba Rivers in 1999 (May and others, 2000) and from Deer Creek during 2010-11 (J.A. Fleck, USGS, written commun., February 3, 2015).

Three of 237 trout, collected from the East Fork Trinity River downstream of the Altoona Mercury Mine, had $\mathrm{Hg}_{\mathrm{T}}$ concentrations $>0.30 \mu \mathrm{g} / \mathrm{g}$, ww, the USEPA water-quality criterion for the protection of human health, (U.S. Environmental Protection Agency, 2001). By contrast, none of the trout collected from the current study had $\mathrm{Hg}_{\mathrm{T}}>0.30 \mu \mathrm{g} / \mathrm{g}$. The highest $\mathrm{Hg}_{\mathrm{T}}$ concentration in rainbow trout from this study was $0.188 \mu \mathrm{g} / \mathrm{g}$ at CLN1 in 2003. Concentrations of $\mathrm{Hg}_{\mathrm{T}}$ in fillets of black bass, piscivorous species from Whiskeytown Lake (May and others, 2012,) ranged from 0.06 to $0.52 \mu \mathrm{g} / \mathrm{g}$, and 5 of the 30 fillets from fish of catchable size ( $>305 \mathrm{~mm}$ in length) exceeded the $0.30 \mu \mathrm{g} / \mathrm{g}$ criterion. Rainbow trout from the watersheds of the Bear and Yuba Rivers in 1999 (May and others, 2000) had $\mathrm{Hg}_{\mathrm{T}}$ concentrations ranging from 0.07 to $0.38 \mu \mathrm{g} / \mathrm{g}$. Mercury concentrations in rainbow trout from Deer Creek were similar to concentrations from this study, ranging from 0.09 to $0.21 \mu \mathrm{g} / \mathrm{g}$, with none exceeding $0.30 \mu \mathrm{g} / \mathrm{g}$ (J.A. Fleck, USGS, written commun., February 3, 2015)

Two riffle sculpin samples collected from CLN1 and CLN2 had $\mathrm{Hg}_{\mathrm{T}}$ concentrations $>0.30 \mu \mathrm{g} / \mathrm{g}$ ( 0.31 and $0.36 \mu \mathrm{g} / \mathrm{g}$, respectively), which were higher than the mean for five samples of sculpin from the East Fork Trinity River $(0.155 \mu \mathrm{g} / \mathrm{g})$. However, most of the sculpin from the Whiskeytown area had mean concentrations of $\mathrm{Hg}_{\mathrm{T}}$ that were $<0.15 \mu \mathrm{g} / \mathrm{g}$ (fig. 23). The highest concentration of $\mathrm{Hg}_{\mathrm{T}}$ in roach from this study was $0.149 \mu \mathrm{g} / \mathrm{g}$ at GRZL in 2002, a value that only exceeded 4 out of the 98 roach collected in 2010 from Bear Creek, Colusa County (Rytuba and others, 2015), an area heavily impacted by $\mathrm{Hg}$ mines. Mean $\mathrm{Hg}_{\mathrm{T}}$ concentrations in roach from Bear Creek ranged from 0.161 to $0.999 \mu \mathrm{g} / \mathrm{g}$, higher than those in roach from the Whiskeytown area. 
Additionally, fillets of 16 rainbow trout from Deer Creek (J.A. Fleck, USGS, written commun., February 3, 2015) and whole bodies of 63 black bass (Micropterus spp.) from Whiskeytown Lake (May and others, 2012) were analyzed for $\mathrm{As}, \mathrm{Cd}, \mathrm{Cr}, \mathrm{Cu}, \mathrm{Ni}, \mathrm{Pb}$, and $\mathrm{Zn}$. The trout from this study with the highest geometric mean concentration of As $(7.78 \mu \mathrm{g} / \mathrm{g}$; range 5.74-11.6 $\mu \mathrm{g} / \mathrm{g})$ was from SCRP, whereas the highest concentration of As in a trout from Deer Creek was $2.75 \mu \mathrm{g} / \mathrm{g}$. The mean As concentration in black bass from Whiskeytown Lake was $1.1 \mu \mathrm{g} / \mathrm{g}$ (range $0.75-1.82 \mu \mathrm{g} / \mathrm{g}$ ). The lower concentration of As in the piscivorous bass from the lake is likely related to a dilution effect observed in the lake compared to Scorpion Gulch (SCRP), an upstream tributary (fig. 1).

The Cd concentration in a trout from WCWL $(1.01 \mu \mathrm{g} / \mathrm{g})$ was higher than the highest concentration in trout from Deer Creek $(0.66 \mu \mathrm{g} / \mathrm{g})$. Bass from Whiskeytown Lake had a mean Cd concentration $(1.11 \mu \mathrm{g} / \mathrm{g})$, similar to that in trout at WCWL.

$\mathrm{Cr}$ was detected in only 19.6 percent of the trout from the Whiskeytown area and 56.3 percent of the trout from Deer Creek. However, the highest concentration of $\mathrm{Cr}$ in trout from Whiskeytown (8.12 $\mu \mathrm{g} / \mathrm{g}$ at MCUS $)$ was higher than the highest concentration of $\mathrm{Cr}$ in trout from Deer Creek $(0.29 \mu \mathrm{g} / \mathrm{g}$; J.A. Fleck, USGS, written commun., February 3, 2015). Chromium was detected in 100 percent of the black bass from Whiskeytown Lake, and the mean Cr concentration for all bass was $2.33 \mu \mathrm{g} / \mathrm{g}$ (May and others, 2012).

The highest concentration of $\mathrm{Cu}$ in trout at LBGL $(8.17 \mu \mathrm{g} / \mathrm{g})$ in the Whiskeytown NRA was similar to the highest concentration of $\mathrm{Cu}$ in trout at Deer Creek $(8.12 \mu \mathrm{g} / \mathrm{g})$. However, trout were not collected from Willow Creek, which had the highest concentration of $\mathrm{Cu}$ in any fish from the Whiskeytown study $(46.1 \mu \mathrm{g} / \mathrm{g}$ in a riffle sculpin at WLCC). The highest concentration of $\mathrm{Cu}$ in bass from Whiskeytown Lake $(9.54 \mu \mathrm{g} / \mathrm{g})$ was higher than that in trout from this study, but the mean for all bass was only $2.18 \mu \mathrm{g} / \mathrm{g}$ (May and others, 2012).

Only 11.8 percent of the trout analyzed from Whiskeytown sites had detectable levels of Ni, with the highest being in a trout from FRGL $(1.06 \mu \mathrm{g} / \mathrm{g}))$. Nickel was detected in 76 percent of the bass from Whiskeytown Lake, and the highest concentration was $172 \mu \mathrm{g} / \mathrm{g}$. None of the 16 rainbow trout collected from Deer Creek in 2010-11 had detectable Ni $(<0.22 \mu \mathrm{g} / \mathrm{g})$.

More than 50 percent of the fish collected during this study in 2002 had $\mathrm{Pb}$ concentrations less than the LOD, and the highest concentration was $0.63 \mu \mathrm{g} / \mathrm{g}$ in a riffle sculpin from Brandy Creek. The highest concentration of $\mathrm{Pb}$ in a trout in 2002 was $0.45 \mu \mathrm{g} / \mathrm{g}$ at MCDS, and, in 2003, the highest concentration was $0.53 \mu \mathrm{g} / \mathrm{g}$ at FRGL. For comparison, $\mathrm{Pb}$ was detected in 39 percent of the fish analyzed from Deer Creek, with the highest concentration being $0.39 \mu \mathrm{g} / \mathrm{g}$ in a brown trout (Salmo trutta) (J.A. Fleck, USGS, written commun., February 3, 2015). Lead was only detected in 10 percent of the bass from Whiskeytown Lake (May and others, 2012), and the highest concentration was $0.21 \mu \mathrm{g} / \mathrm{g}$.

Rainbow trout from this study generally had higher concentrations of $\mathrm{Zn}(62.8-219 \mu \mathrm{g} / \mathrm{g})$ than did trout from Deer Creek (21-98 $\mu \mathrm{g} / \mathrm{g}$ ) (J.A. Fleck, USGS, written commun., February 3, 2015). Zinc concentrations in bass from Whiskeytown Lake ranged from 48.4 to $121 \mu \mathrm{g} / \mathrm{g}$ (May and others, 2012), and overlapped ranges of $\mathrm{Zn}$ concentrations in trout from this study and Deer Creek. 


\section{Acknowledgments}

The U.S. Geological Survey (USGS)-National Park Service (NPS) Water Quality Cooperative Program provided funding for this study. Numerous individuals at the USGS helped to collect and process samples for these studies, including Michael Atamian, Marissa Wulff, Darrin Bergen, Michael Casselberry, Connie Clapton, Skylar Feltman, David Kelly, Sandor Kelly, Erik Oshel, and Bonnie Trejo. Julie Yee of USGS provided statistical support. Personnel from Whiskeytown National Recreation Area (NRA) who provided logistical support or assisted with sampling were Windy Bunn, Russ Weatherbee, Brian Rasmussen, and Barbara Alberti. Donna Knifong (USGS) assisted with graphics. Robert Taylor, Director of the Trace Element Research Laboratory (TERL), oversaw all chemical analyses of biological samples. We thank T. Kimball, M. Ricca, and L. Brown for helpful comments on previous drafts of this report. Specimens were collected for this study under authority of Scientific Collecting Permit SC-1243 granted to Roger Hothem by the California Department of Fish and Wildlife.

\section{References Cited}

Alpers, C.N., Hunerlach, M.P., May, J.T., Hothem, R.L., Taylor, H.E., Antweiler, R.C., DeWild, J.F., and Lawler, D.A., 2005, Geochemical characterization of water, sediment, and biota affected by mercury contamination and acidic drainage from historical gold mining, Greenhorn Creek, Nevada County, California, 1999-2001: U.S. Geological Survey Scientific Investigations Report 2004-5251, 278 p., http://pubs.water.usgs.gov/sir2004-5251.

Andrews, E.J., Bennett, B.T., Clark, J.D., Houpt, K.A., Pascoe, P.J., Robinson, G.W., and Boyce, J.R., 1993, 1993 report of the American Veterinary Medical Association panel on euthanasia: Journal of the American Veterinary Medical Association, v. 202, p. 229-249.

Axtmann, E.V., Cain, D.J., and Luoma, S.N., 1997, Effect of tributary inflows on the distribution of trace metals in fine-grained bed sediments and benthic insects of the Clark Fork River, Montana: Environmental Science and Technology, v. 31, p. 750-758.

Baltz, D.M., Moyle, P.B., and Knight, N.J., 1982, Competitive interactions between benthic stream fishes, riffle sculpin, Cottus gulosus, and speckled dace, Rhinichthys osculus: Canadian Journal of Fisheries and Aquatic Sciences, v. 39, p. 1,502-1,511.

Barbour, M.T., Gerritsen, J., Snyder, B.D., and Stribling, J.B., 1999, Rapid bioassessment protocols for use in streams and wadeable rivers-Periphyton, benthic macroinvertebrates, and fish (2d ed.): U.S. Environmental Protection Agency, Office of Water, EPA 841-B-99-002.

Blaustein, A.R., Wake, D.B., and Sousa W.P., 1994, Amphibian declines-Judging stability, persistence, and susceptibility of populations to local and global extinctions: Conservation Biology, v. 8, p. 60-71.

Borgmann, U., Couillard, Y., and Grapentine, L.C., 2007, Relative contribution of food and water to 27 metals and metalloids accumulated by caged Hyalella azteca in two rivers affected by metal mining: Environmental Pollution, v. 145, p. 753-765.

Brown, L.R., May, J.T., and Wulff, M., 2012, Associations of benthic macroinvertebrate assemblages with environmental variables in the upper Clear Creek Watershed, California: Western North American Naturalist, v. 72, p. 473-494.

Buchman, M.F., 2008, NOAA screening quick reference tables, NOAA OR\&R Report 08-1: Seattle, Washington, National Oceanic and Atmospheric Administration, Office of Response and Restoration Division, $34 \mathrm{p}$. 
Cain, D.J., Luoma, S.N., Carter, J.L., and Fend, S.V., 1992, Aquatic insects as bioindicators of trace element contamination in cobble-bottom rivers and streams: Canadian Journal of Fisheries and Aquatic Sciences, v. 49, p. 2,141-2,154.

California Department of Water Resources, 1985, The Greenhorn and Afterthought Mines-A plan for the control and abatement of acid and heavy metal pollution, Shasta County, California: California Department of Water Resources, Northern District, memorandum report prepared for the Central Valley Regional Water Quality Control Board, July 1985.

California Environmental Protection Agency, 2009, FISH—Safe Eating Guidelines: Sacramento, California Environmental Protection Agency, Office of Environmental Health Hazard Assessment., accessed January 8, 2014, at http://www.oehha.ca.gov/fish/so_cal/index.html/.

Clark, W.B., 1970, Gold districts of California: Sacramento, California Division of Mines and Geology, Bulletin 193.

Cooke, A.S., 1981, Tadpoles as indicators of harmful levels of pollution in the field: Environmental Pollution, Series A, v. 25, p. 123-133.

Davidson, P.W., Meyers, G.J., Cox, C., Axtell, C., Shamlaye, C., Sloane-Reeves, J., Cernichiari, E., Needham, L., Choi, A., Wang, Y., Berlin, M., and Clarkson, T.W., 1998, Effects of prenatal and postnatal methylmercury exposure from fish consumption on neurodevelopment—Outcomes at 66 months of age in the Seychelles child development study: Journal of the American Medical Association, v. 280, p. 701-707.

Dial, N.A., 1976, Methylmercury-Teratogenic and lethal effects in frog embryos: Teratology, v. 13, p. 327-333.

Fausch, K.D., Karr, J.R., and Yant, P.R., 1984, Regional application of an index of biotic integrity based on stream fish communities: Transactions of the American Fisheries Society, v. 113, p. 39-55.

Fitzpatrick, F.A., Waite, I.R., D’Arconte, P.J., Meador, M.R., Maupin, M.A., and Gurtz, M.E., 1998, Revised methods for characterizing stream habitat in the National Water-Quality Assessment Program: U.S. Geological Survey, Water-Resources Investigations Report 98-4052, 67 p.

Fore, L.S., Karr, J.R., and Wisseman, R.W., 1996, Assessing invertebrate responses to human activities: evaluating alternative approaches: Journal of the North American Benthological Society, v.15, p. 212-231.

Gillespie, D.C., and Scott, D.P., 1971, Mobilization of mercuric sulfide from sediment into fish under aerobic conditions: Journal of the Fisheries Research Board of Canada, v. 28, p. 1,807-1,808.

Harding, J.S., 2005, Impacts of metals and mining on stream communities, in Moore, T.A., Black, A., Centeno, J.A., Harding, J.S., and Trumm, D.A., eds., Metal contaminants in New Zealand: Sources, treatments, and effects on ecology and human health: Resolutionz Press, Christchurch, New Zealand, p. 343-357.

Harrington, J.M., 1999, California stream bioassessment procedures: Rancho Cordova, California Department of Fish and Game, Water Pollution Control Laboratory.

Hughes, R.M., and Gammon, J.R., 1987, Longitudinal changes in fish assemblages and water quality in the Willamette River, Oregon: Transactions of the American Fisheries Society, v. 116, p. 196-209.

Jennings, M.R., and Hayes, M.P., 1994, Amphibian and reptile species of special concern in California: Rancho Cordova, California Department of Fish and Game, Inland Fisheries Division, 255 p.

Karr, J.R., 1981, Assessment of biotic integrity using fish communities: Fisheries, v. 6, p. 21-27.

Karr, J.R., and Chu, E.W., 1999, Restoring life in running waters-Better biological monitoring: Washington, D.C., Island Press, 206 p.

Lancaster, J., Real, M., Juggins, S., Monteith, D.T., Flower, R.J., and Beaumont, W.R.C., 1996, Monitoring temporal changes in the biology of acid waters: Freshwater Biology, v. 36, p. 179-201. 
Long, E.R., MacDonald, D.D., Smith, S.L., and Calder, F.D., 1995, Incidence of adverse biological effects within ranges of chemical concentrations in marine and estuarine sediments: Environmental Management, v. 19, p. 81-97.

Lydon, P.A., and O'Brien, J.C., 1974, Mines and mineral resources of Shasta County, California: California Division of Mines and Geology, County Report 6, 154 p.

May, J.T., Hothem, R.L., and Alpers, C.N., 2005, Mercury concentrations in fishes from select water bodies in Trinity County, California, 2000-2002: U.S. Geological Survey Open-File Report 20051321, 14 p., http://pubs.usgs.gov/of/2005/1321/USGS 2005-1321.pdf.

May, J.T., Hothem, R.L., Alpers, C.N., and Law, M.A., 2000, Mercury bioaccumulation in fish in a region affected by historic gold mining - The South Yuba River, Deer Creek, and Bear River watersheds, California, 1999: U.S. Geological Survey Open-File Report 2000-367, 30 p., http://pubs.usgs.gov/of/2000/0367/report.pdf.

May, J.T., Hothem, R.L., Bauer, M.L., and Brown, L.R., 2012, Concentrations of mercury and other metals in black bass (Micropterus spp.) from Whiskeytown Lake, Shasta County, California, 2005: U.S. Geological Survey Open-File Report 2011-1297, 16 p., http://pubs.usgs.gov/of/2011/1297/pdf/ofr20111297.pdf.

Merritt, R.W., and Cummins, K.W., 1995, An introduction to the aquatic insects of North America (2d ed.): Dubuque, Iowa, Kendall/Hunt Publishing, 862 p.

Moore, J.N., 2002, Trace metals in sediments from mine-impacted rivers-Clear Creek, California Project: Final report for award No. 02WRAG001 submitted to the National Park Service, $133 \mathrm{p}$.

Moore, J.N., and Hughes, D., 2003, Trace metals in sediments of a mine impacted river basin-Clear Creek, California Project: Final Report submitted to the National Park Service, $136 \mathrm{p}$.

Neumann, R.M., and Ward, S.M., 1999, Bioaccumulation and biomagnification of mercury in two warmwater fish communities: Journal of Freshwater Ecology, v. 14, p. 487-497.

Pan, Y., Stevenson, R.J., Hill, B.H., Herlihy, A.T., and Collins, G.B., 1996, Using diatoms as indicators of ecological conditions in lotic systems - A regional assessment: Journal of the North American Benthological Society, v. 15, p. 481-495.

Power, M.E., 1992, Habitat heterogeneity and the functional significance of fish in river food webs: Ecology, v. 73, p. 1,675-1,688.

Rehn, A.C., Ode, P.R., and May, J.T., 2005, Development of a benthic index of biotic integrity (B-IBI) for wadeable streams in northern coastal California and its application to regional 305(b) assessment: Final technical report to the California State Water Resources Control Board, California Department of Fish and Game, Aquatic Bioassessment Laboratory, Rancho Cordova, California, http:/www.waterboards.ca.gov/ water_issues/programs/swamp/docs/reports/ final_north_calif_ibi.pdf.

Rytuba, J.J., Hothem, R.L., Brussee, B.E., and Goldstein, D.N., 2011, Impact of mine and natural sources of mercury on water, sediment, and biota in Harley Gulch adjacent to the Abbott-Turkey Run mine, Lake County, California: U.S. Geological Survey Open-File Report 2011-1265, 105 p., http://pubs.usgs.gov/of/2011/1265/of2011-1265.pdf.

Rytuba, J.J., R.L. Hothem, B.E. Brussee, D.N. Goldstein, and J.T. May. 2015. Environmental assessment of water, sediment, and biota collected from the Bear Creek Watershed, Colusa County, California: U.S. Geological Survey Open-File Report, 2013-1070, 83p., http://pubs.usgs.gov/of/2013/1070/downloads/ofr2013-1070.pdf.

Saouter, E., Hare, L., Campbell, P.G.C., Boudou, A., and Ribeyre, F., 1993, Mercury accumulation in the burrowing mayfly Hexagenia rigida (Ephemeroptera) exposed to $\mathrm{CH}_{3} \mathrm{HgCl}$ or $\mathrm{HgCl}_{2}$ in water and sediment: Water Resources, v. 27, p. 1,041-1,048.

SAS Institute Inc. 2010. SAS OnlineDoc ${ }^{\circledR}$ 9.2: Cary, North Carolina, SAS Institute Inc. 
Shelton, L. R., and Capel, P.D., 1994, Guidelines for collecting and processing samples of stream bed sediment for analysis of trace elements and organic contaminants for the National Water-Quality Assessment Program: U.S. Geological Survey Open-File Report 94-458, 20 p., http://pubs.usgs.gov/of/1994/0458/report.pdf.

Slotton, D.G., Ayers, S.M., Reuter, J.E., and Goldman, C.R., 1995, Gold mining impacts on food chain mercury in northwestern Sierra Nevada streams: Technical Completion Report for the University of California Water Resources Center, Project W-816, August 1995, 46 p.

Slotton, D.G., Ayers, S.M., Suchanek, T.H., Weyand, R.D., and Liston, A.M., 2004, Mercury bioaccumulation and trophic transfer in the Cache Creek watershed of California, in relation to diverse aqueous mercury exposure conditions: CALFED Bay-Delta Program Project, Component 5B, Final Report, Assessment of ecological and human health impacts of mercury in the San Francisco Bay-Delta watershed.

Suter, G.W. II, and Tsao, C.L., 1996, Toxicological benchmarks for screening potential contaminants of concern for effects on aquatic biota-1996 revision: Prepared by Risk Assessment Program, Health Sciences Research Division, Oak Ridge, Tennessee, for U.S. Department of Energy, 54 p.

Tippets, W.E., and Moyle, P.B., 1978, Epibenthic feeding by rainbow trout (Salmo gairdneri) in the McCloud River, California: Journal of Animal Ecology, v. 47, p. 549-559.

Toogood, A.C., 1978, Historic resource study-Whiskeytown National Recreation Area, California: National Park Service, Denver Service Center, Historic Preservation Team, Denver, Colorado, 177 p.

U.S. Environmental Protection Agency, 1994b, Method 200.7, Revision 4.4, EMMC version: Determination of metals and trace elements in water and wastes by inductively coupled plasmaatomic emission spectrometry: U. S. Environmental Protection Agency, Environmental Monitoring Systems Laboratory, Office of Research and Development, Cincinnati, Ohio, 58 p., http://www.caslab.com/EPA-Methods/PDF/200_7.pdf

U.S. Environmental Protection Agency, 1994a, Method 200.15, Revision 1.2 EMMC version: Determination of metals and trace elements in water by ultrasonic nebulization inductively coupled plasma-atomic emission spectrometry, U. S. Environmental Protection Agency, Environmental Monitoring Systems Laboratory, Office of Research and Development, Cincinnati, Ohio, 49 p., http://water.epa.gov/scitech/methods/cwa/bioindicators/upload/2007 07_10_methods_method_200_15.pdf

U.S. Environmental Protection Agency, 2001, Water quality criterion for protection of human healthMethylmercury: U.S. Environmental Protection Agency, Office of Water, EPA-823-R-01-001, 269 p., http://water.epa.gov/scitech/swguidance/standards/criteria/ health/upload/2009_01_15_criteria_methylmercury_mercury-criterion.pdf.U.S. Environmental Protection Agency, 2005 , Method 245.7, Revision 2.0: Mercury in water by cold vapor atomic fluorescence spectrometry, U.S. Environmental Protection Agency, Office of Water, Office of Science and Technology Engineering and Analysis Division, Washington, D.C., EPA-821-R-05-001, $30 \mathrm{p}$.

U.S. Environmental Protection Agency, 2011, 2011 edition of the drinking water standards and health advisories: U.S. Environmental Protection Agency, Office of Water, Washington, D.C., EPA 820-R11-002, 12 p.

U.S. Fish and Wildlife Service, 1997, Quality assurance of chemical measurements reported under contract to the Patuxent Analytical Control Facility: Patuxent Analytical Control Facility, 9 p. with attachments.

Wayland, M., and Crosley, R., 2006, Selenium and other trace elements in aquatic insects in coal mineaffected streams in the Rocky Mountains of Alberta, Canada: Archives of Environmental Contamination and Toxicology, v. 50, p. 511-522. 
White, R.F., Grandjean, P.A., and Weihe, P., 1995, An overview of human studies on CNS effects of methylmercury, in Proceedings of the National Forum on Mercury in Fish: U.S. Environmental Protection Agency, Office of Water, EPA 823-R-95-002, Washington, D.C., p. 109-112.

Wiener, J.G., and Spry. D.J., 1996, Toxicological significance of mercury in freshwater fish, in Beyer, W.N., Heinz, G.H., and Redmon-Norwood, A.W., eds., Environmental contaminants in wildlifeInterpreting tissue concentrations: Boca Raton, Florida, Lewis Publishers, p. 297-339.

Williams, B.K., Nichols, J.D., and Conroy, M.J., 2002, Analysis and management of animal populations-Modeling, estimation, and decision making. San Diego, Academic Press, 817 p.

Wolfe, M.E., Schwarzbach, S.E., and Sulaiman, R.A., 1998, Effects of mercury on wildlife-A comprehensive review: Environmental Toxicology and Chemistry, v. 17, p. 146-160.

Wulff, M.L., May, J.T., and Brown, L.R., 2012, Upper Clear Creek watershed aquatic chemistry and biota surveys, 2004-5, Whiskeytown National Recreation Area, Shasta County, California: U.S. Geological Survey Open-File Report 2012-1173, 8 p., http://pubs.usgs.gov/of/2012/1173/

pdflofr20121173.pdf. 


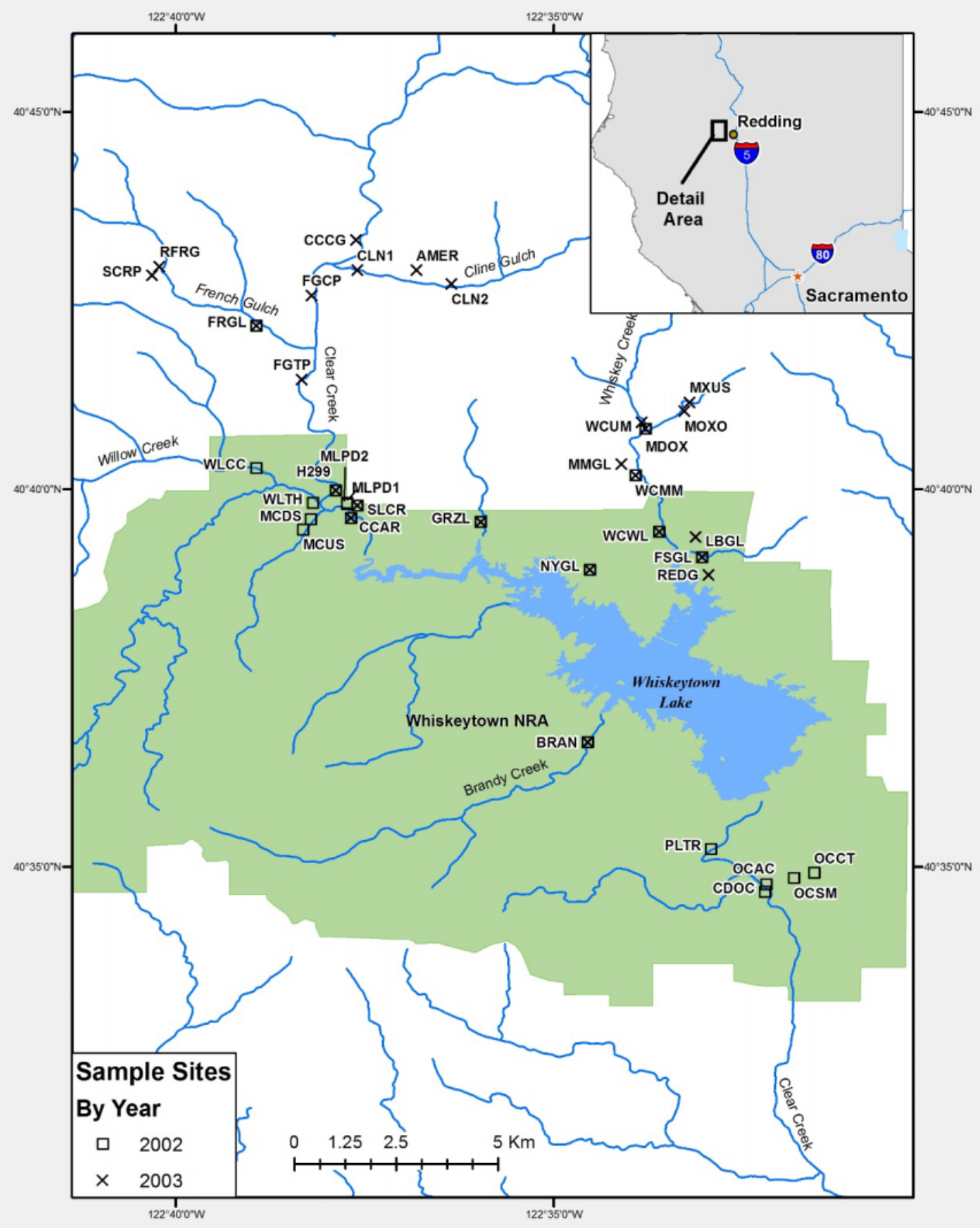

Figure 1. Map showing sites sampled for biota in the Whiskeytown National Recreation Area and nearby Clear Creek watershed, northwestern California, 2002-03. (See table 1 for definitions of site codes.) 

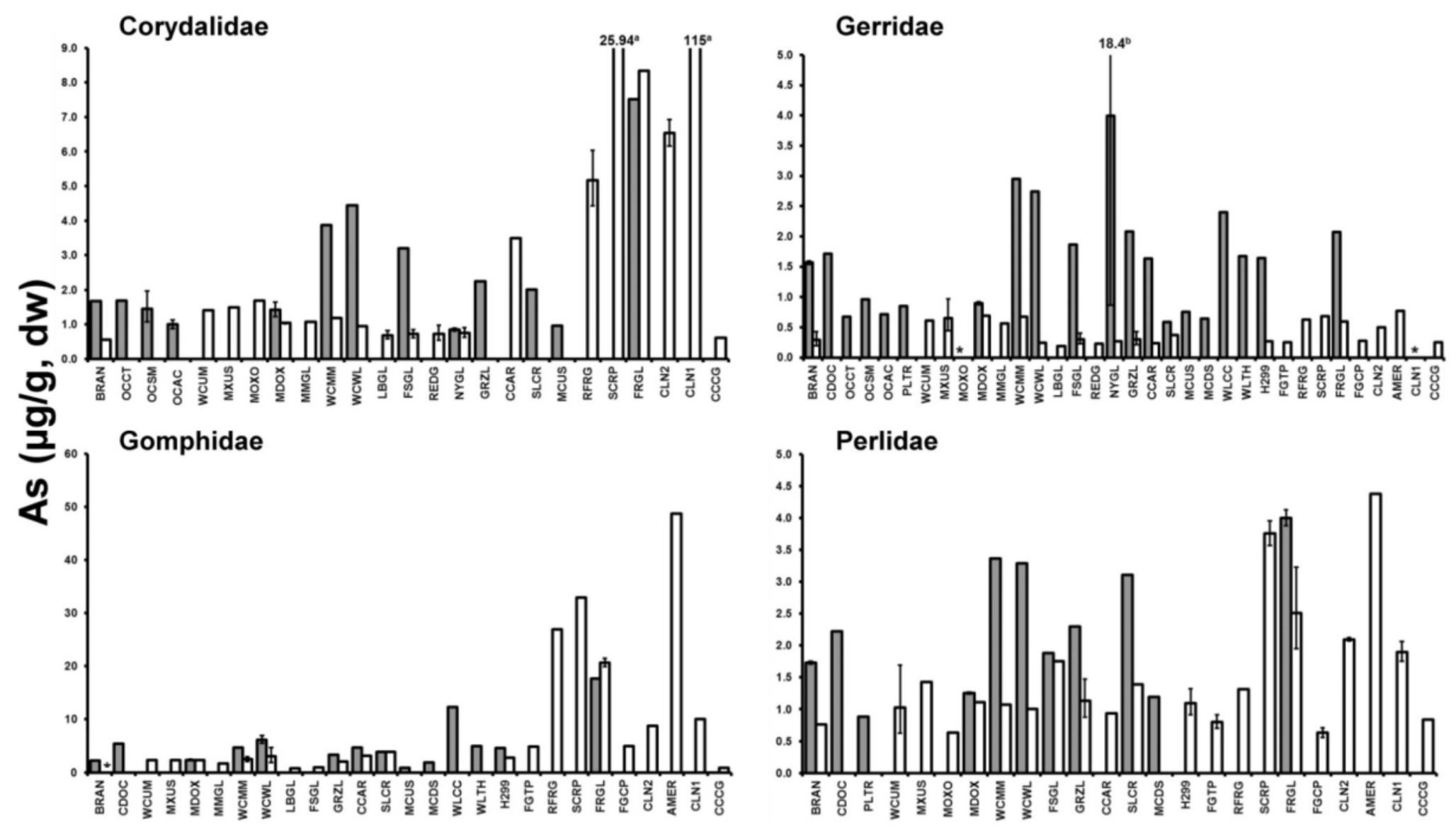

\section{SITE}

Figure 2. Bar graphs showing geometric mean (and range) of arsenic (As) concentrations (micrograms per gram, dry weight [ $\mu \mathrm{g} / \mathrm{g}$, dw]) in larval dobsonflies (Megaloptera: Corydalidae), adult water striders (Hemiptera: Gerridae), larval dragonflies (Odonata: Gomphidae), and larval stoneflies (Plecoptera: Perlidae) collected from Whiskeytown National Recreation Area and vicinity, northwestern California, 2002 (shaded) and 2003 (clear). No bar means that taxon was not collected (see appendix 1). ${ }^{*}$ means less than detection limit. (See table 1 for definitions of site codes.) For Corydalidae, the concentration of As in 2003 from CLN1 $(115 \mu \mathrm{g} / \mathrm{g})$ and both the mean $(25.9 \mu \mathrm{g} / \mathrm{g})$ and range $(23.7-28.4 \mu \mathrm{g} / \mathrm{g})$ from SCRP exceeded the range of the graph. For Gerridae, the upper range of the concentration of As in 2002 from NYGL (18.4 $\mu \mathrm{g} / \mathrm{g})$ exceeded the range of the graph. 


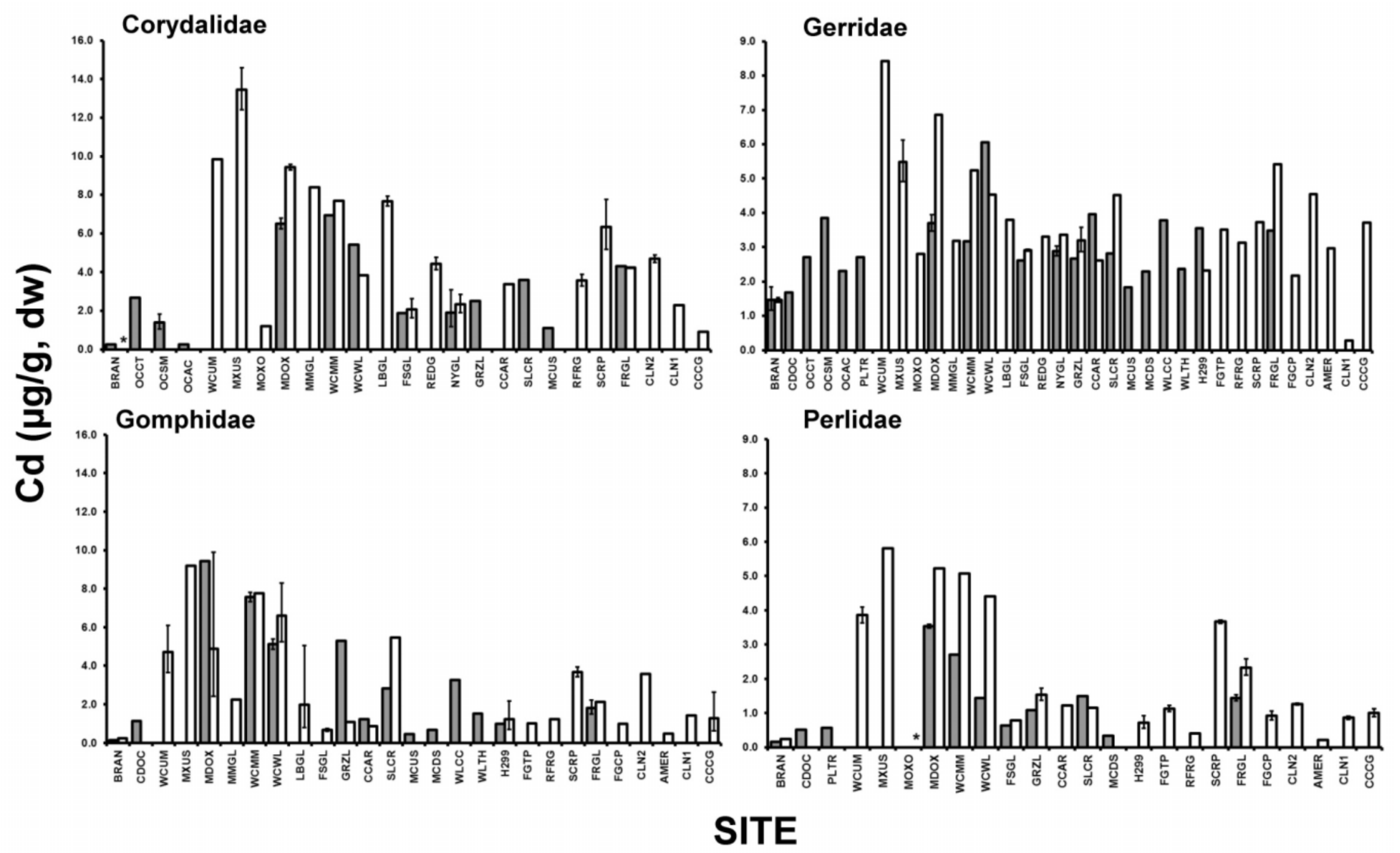

Figure 3. Bar graphs showing geometric mean (and range) of cadmium (Cd) concentrations (micrograms per gram, dry weight [ $\mu \mathrm{gg} / \mathrm{g}$, dw]) in larval dobsonflies (Megaloptera: Corydalidae), adult water striders (Hemiptera: Gerridae), larval dragonflies (Odonata: Gomphidae), and larval stoneflies (Plecoptera: Perlidae) collected from Whiskeytown National Recreation Area and vicinity, northwestern California, 2002 (shaded) and 2003 (clear). No bar means that taxon was not collected (see appendix 1). * means less than detection limit. (See table 1 for definitions of site codes.) 

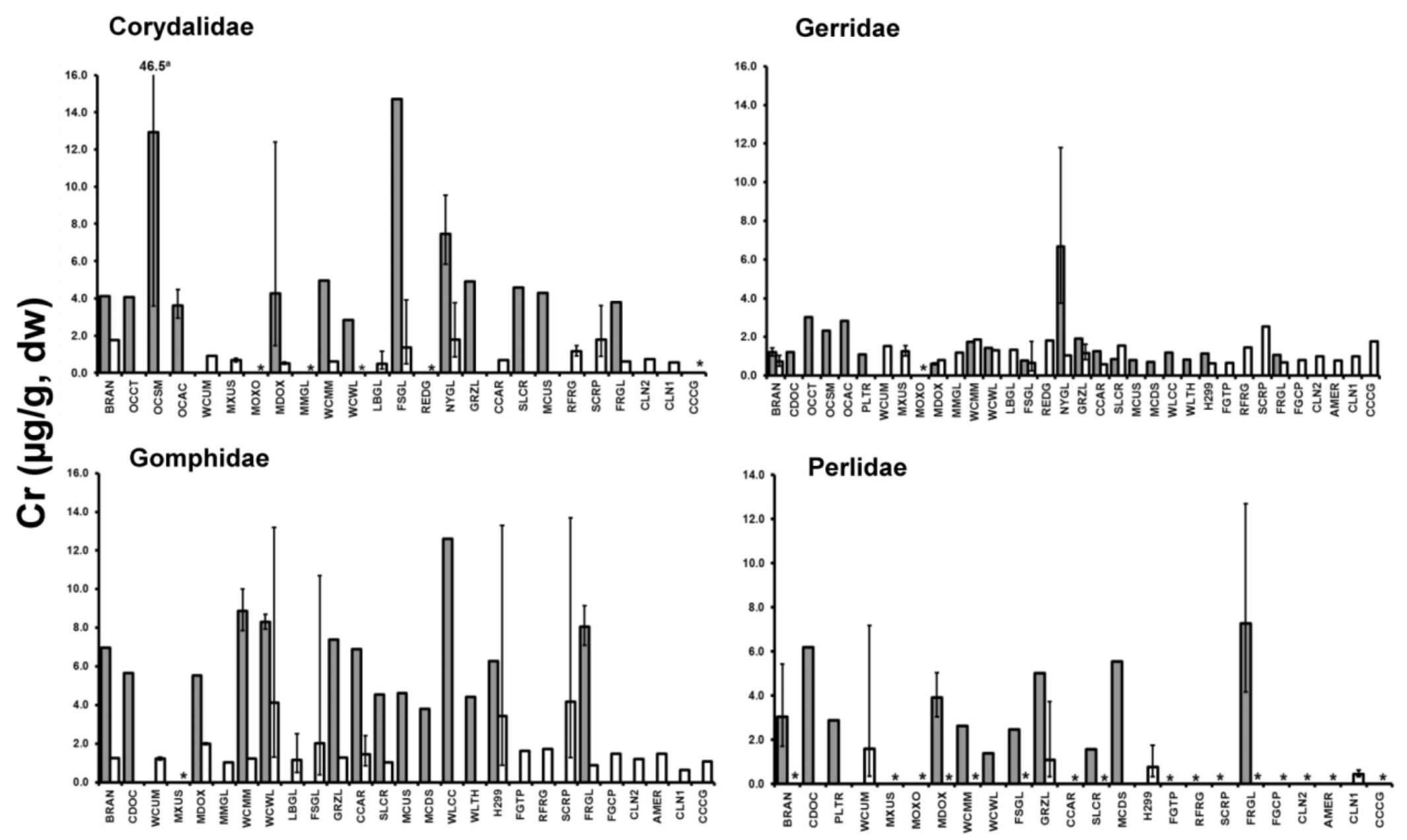

SITE

Figure 4. Bar graphs showing geometric mean (and range) of chromium $(\mathrm{Cr})$ concentrations (micrograms per gram, dry weight [ $\mu \mathrm{g} / \mathrm{g}$, dw]) in larval dobsonflies (Megaloptera: Corydalidae), adult water striders (Hemiptera: Gerridae), larval dragonflies (Odonata: Gomphidae), and larval stoneflies (Plecoptera: Perlidae) collected from Whiskeytown National Recreation Area and vicinity, northwestern California, 2002 (shaded) and 2003 (clear). No bar means that taxon was not collected (see appendix 1). *means less than detection limit. (See table 1 for definitions of site codes.) For Corydalidae, the upper range of $\mathrm{Cr}$ concentration from OCSM in $2002(46.5 \mu \mathrm{g} / \mathrm{g})$ exceeded the range of the graph. 

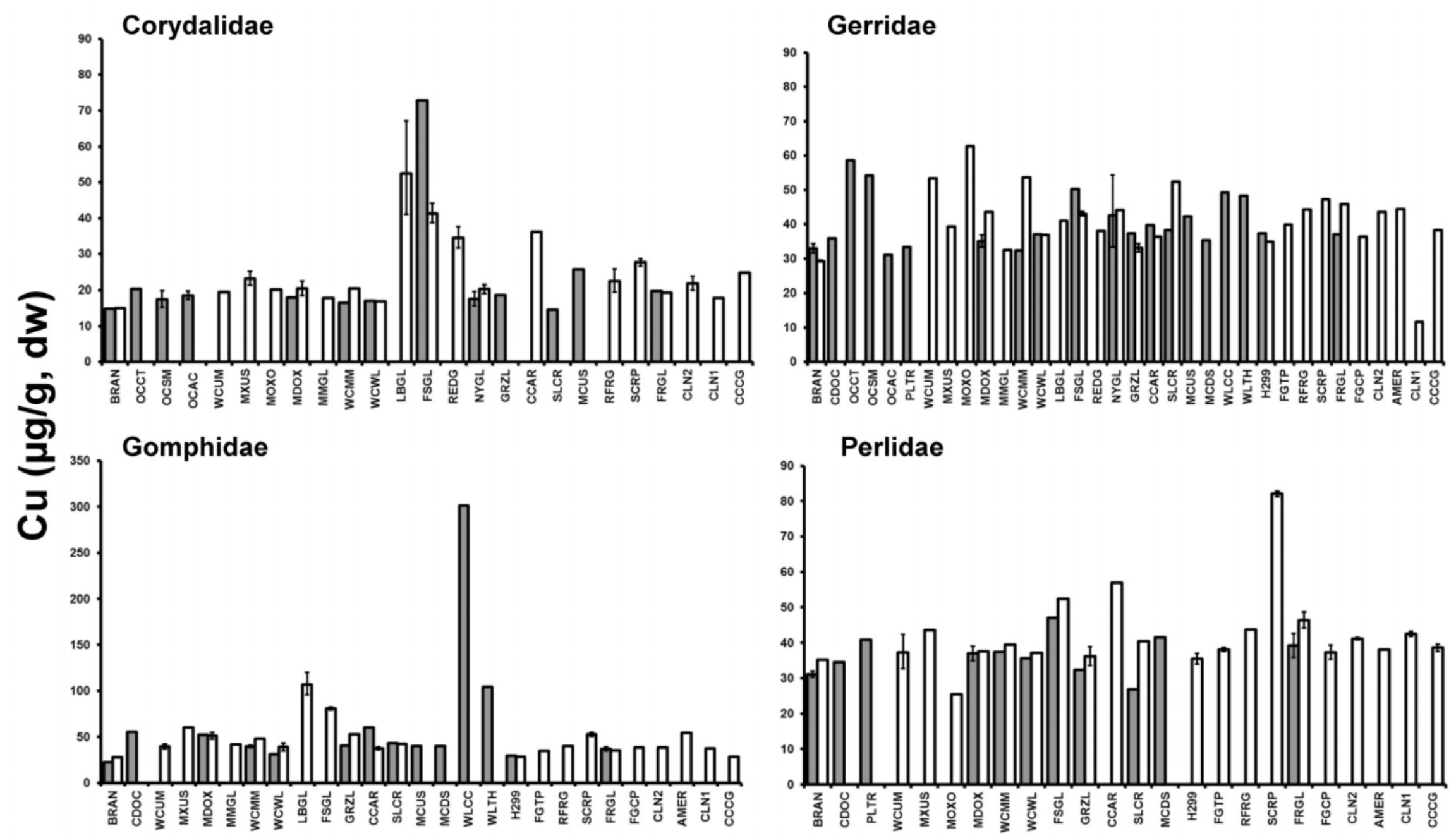

SITE

Figure 5. Bar graphs showing geometric mean (and range) of copper ( $\mathrm{Cu}$ ) concentrations (micrograms per gram, dry weight [ $\mu \mathrm{g} / \mathrm{g}$, dw]) in larval dobsonflies (Megaloptera: Corydalidae), adult water striders (Hemiptera: Gerridae), larval dragonflies (Odonata: Gomphidae), and larval stoneflies (Plecoptera: Perlidae) collected from Whiskeytown National Recreation Area and vicinity, northwestern California, 2002 (shaded) and 2003 (clear). No bar means that taxon was not collected (see appendix 1). ${ }^{*}$ means less than detection limit. (See table 1 for definitions of site codes.) 

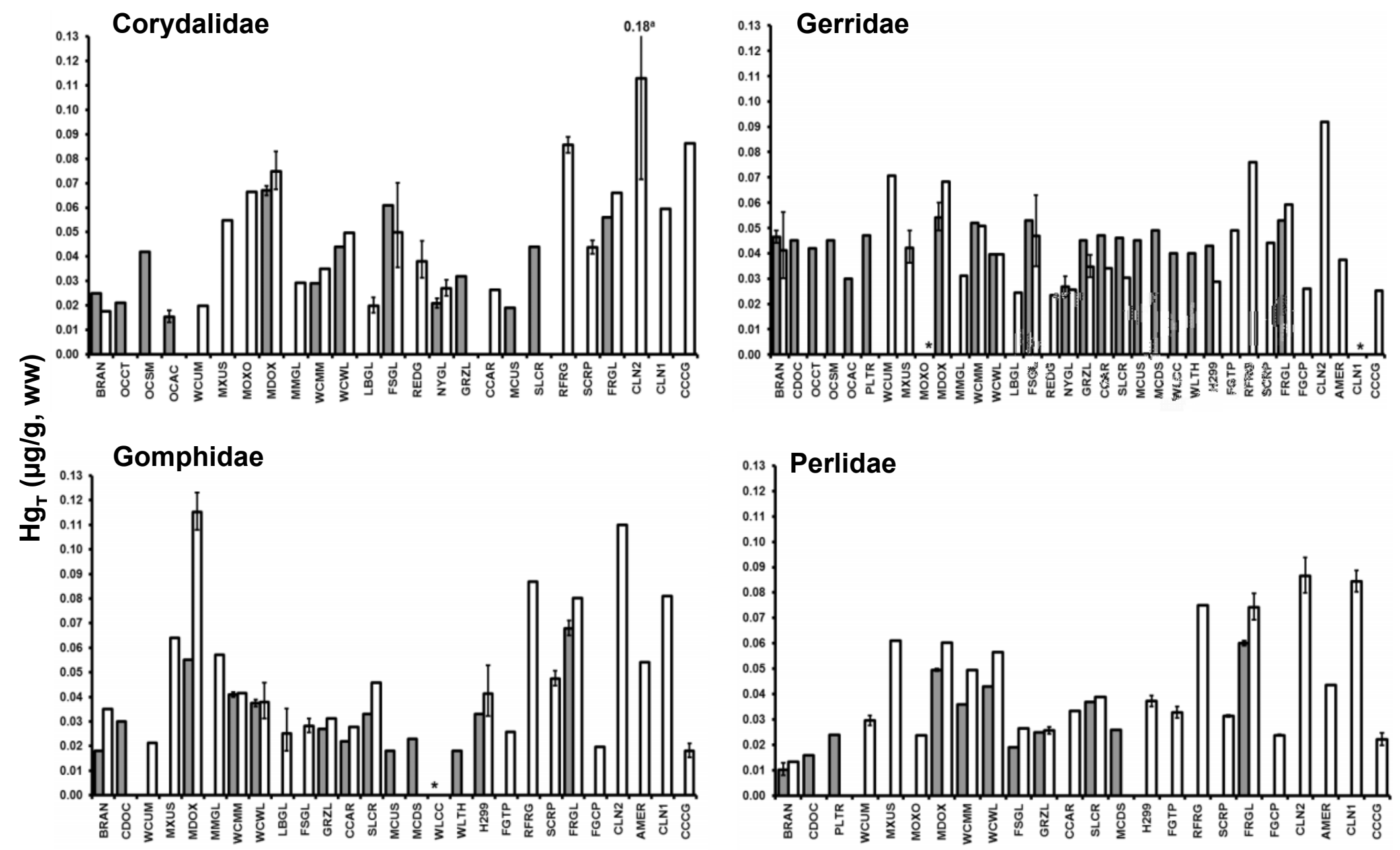

\section{SITE}

Figure 6. Bar graphs showing geometric mean (and range) of total mercury $\left(\mathrm{Hg}_{\mathrm{T}}\right)$ concentrations (micrograms per gram, wet weight [ $\mu \mathrm{g} / \mathrm{g}$, ww]) in larval dobsonflies (Megaloptera: Corydalidae), adult water striders (Hemiptera: Gerridae), larval dragonflies (Odonata: Gomphidae), and larval stoneflies (Plecoptera: Perlidae) collected from Whiskeytown National Recreation Area and vicinity, northwestern California, 2002 (shaded) and 2003 (clear). No bar means that taxon was not collected (see appendix 1). * means less than detection limit. (See table 1 for definitions of site codes.) For Corydalidae, the upper range of $\mathrm{Hg}_{\mathrm{T}}$ concentration at CLN2 in $2003(0.18 \mu \mathrm{g} / \mathrm{g}$, ww) exceeded the range of the graph. 

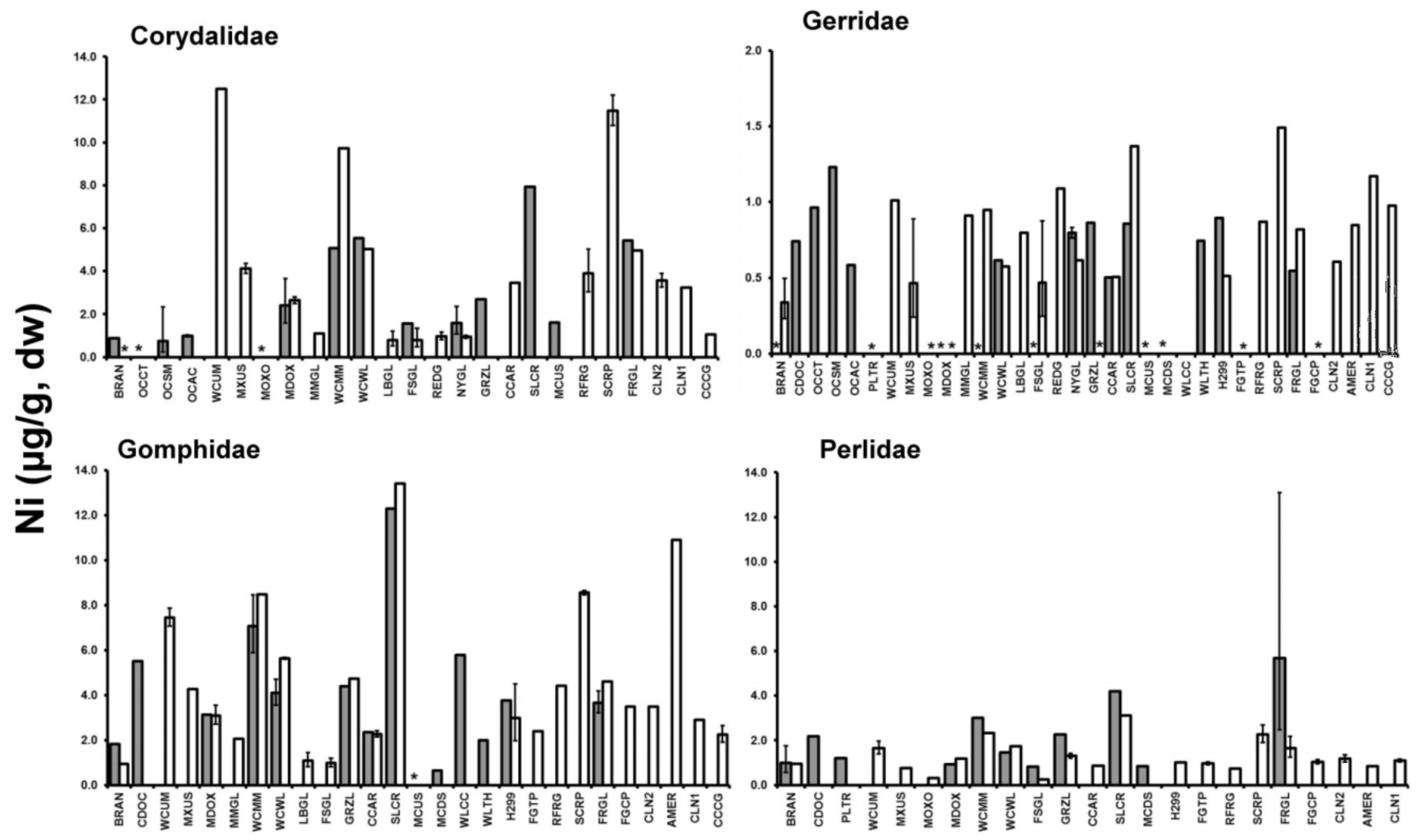

\section{SITE}

Figure 7. Bar graphs showing geometric mean (and range) of nickel (Ni) concentrations (micrograms per gram, dry weight [( $\mu \mathrm{g} / \mathrm{g}, \mathrm{dw}])$ in larval dobsonflies (Megaloptera: Corydalidae), adult water striders (Hemiptera: Gerridae), larval dragonflies (Odonata: Gomphidae), and larval stoneflies (Plecoptera: Perlidae) collected from Whiskeytown National Recreation Area and vicinity, northwestern California, 2002 (shaded) and 2003 (clear). No bar means that taxon was not collected (see appendix 1). * means below detection limit. (See table 1 for definitions of site codes.) 

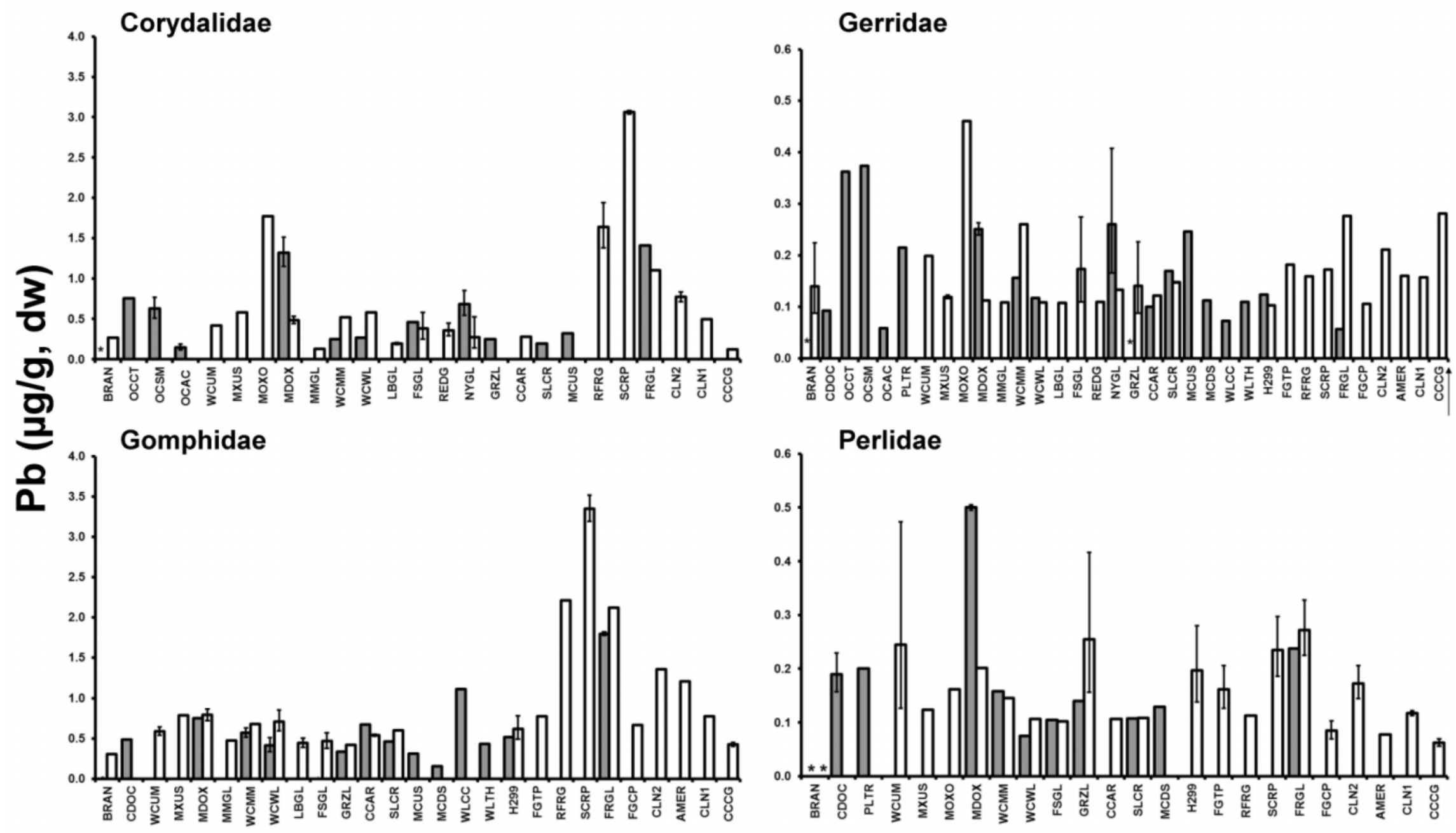

\section{SITE}

Figure 8. Bar graphs showing geometric mean (and range) of lead ( $\mathrm{Pb})$ concentrations (micrograms per gram, dry weight [ $\mu \mathrm{g} / \mathrm{g}$, dw]) in larval dobsonflies (Megaloptera: Corydalidae), adult water striders (Hemiptera: Gerridae), larval dragonflies (Odonata: Gomphidae), and larval stoneflies (Plecoptera: Perlidae) collected from Whiskeytown National Recreation Area and vicinity, northwestern California, 2002 (shaded) and 2003 (clear). No bar means that taxon was not collected (see appendix 1). * means less than detection limit. (See table 1 for definitions of site codes.) 

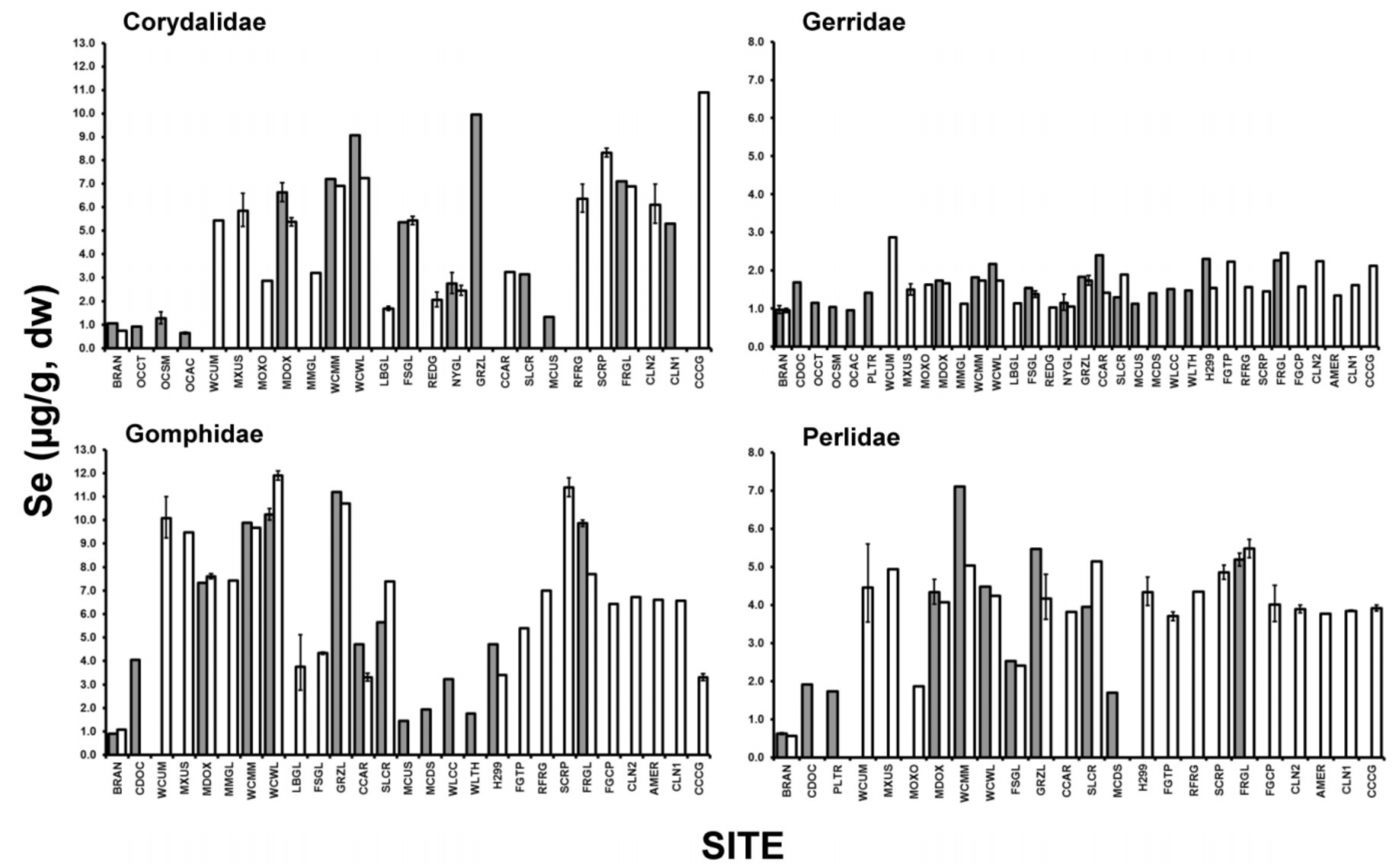

Figure 9. Bar graphs showing geometric mean (and range) of selenium (Se) concentrations (micrograms per gram, dry weight [ $\mu \mathrm{g} / \mathrm{g}$, dw]) in larval dobsonflies (Megaloptera: Corydalidae), adult water striders (Hemiptera: Gerridae), larval dragonflies (Odonata: Gomphidae), and larval stoneflies (Plecoptera: Perlidae) collected from Whiskeytown National Recreation Area and vicinity, northwestern California, 2002 (shaded) and 2003 (clear). No bar means that taxon was not collected (see appendix 1). ${ }^{*}$ means less than detection limit. (See table 1 for definitions of site codes.) 

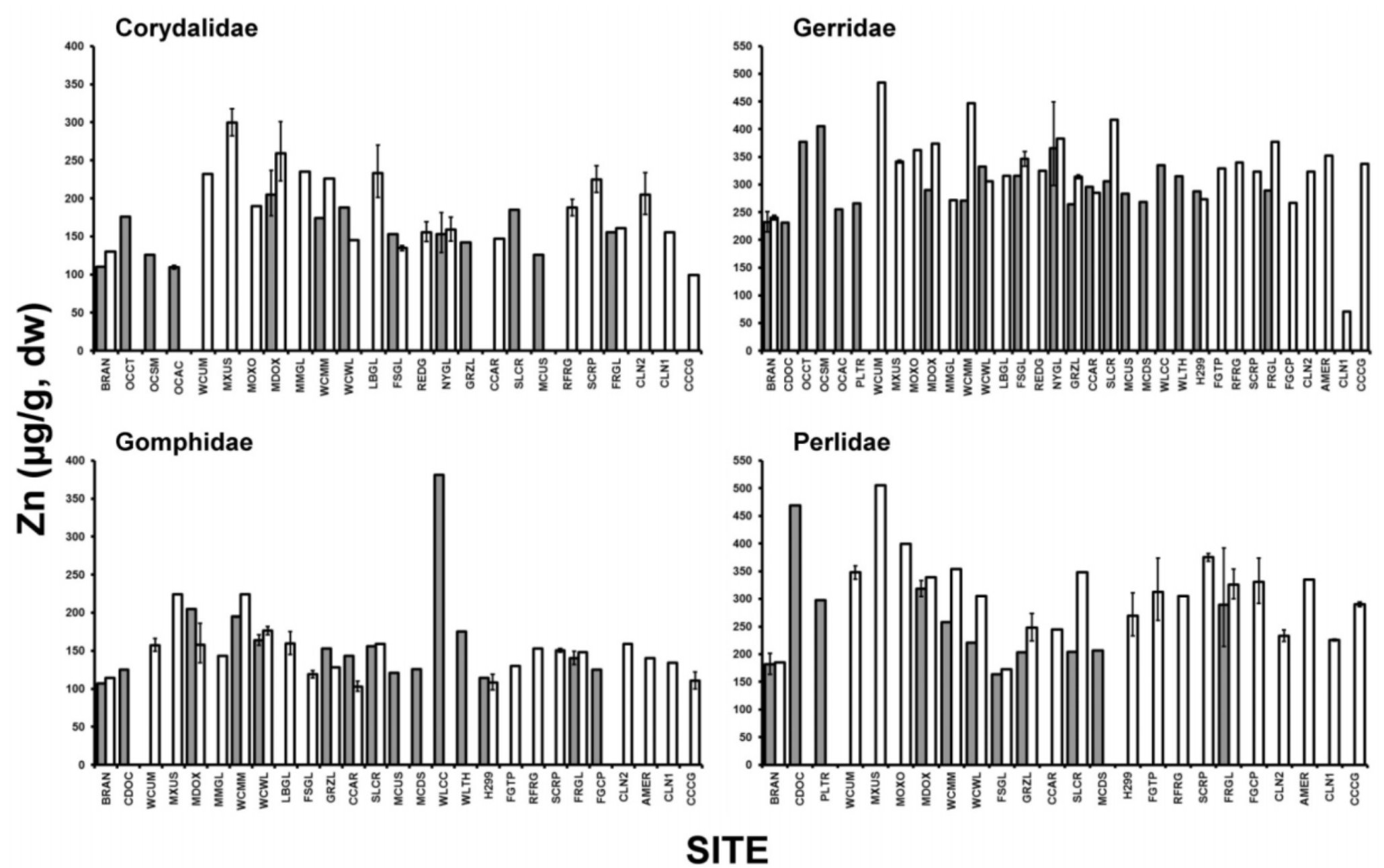

Figure 10. Bar graphs showing geometric mean (and range) of zinc ( $\mathrm{Zn})$ concentrations (micrograms per gram, dry weight [ $\mu \mathrm{g} / \mathrm{g}$, $\mathrm{dw}]$ ) in larval dobsonflies (Megaloptera: Corydalidae), adult water striders (Hemiptera: Gerridae), larval dragonflies (Odonata: Gomphidae), and larval stoneflies (Plecoptera: Perlidae) collected from Whiskeytown National Recreation Area and vicinity, northwestern California, 2002 (shaded) and 2003 (clear). No bar means that taxon was not collected (see appendix 1). * means less than detection limit. (See table 1 for definitions of site codes.) 


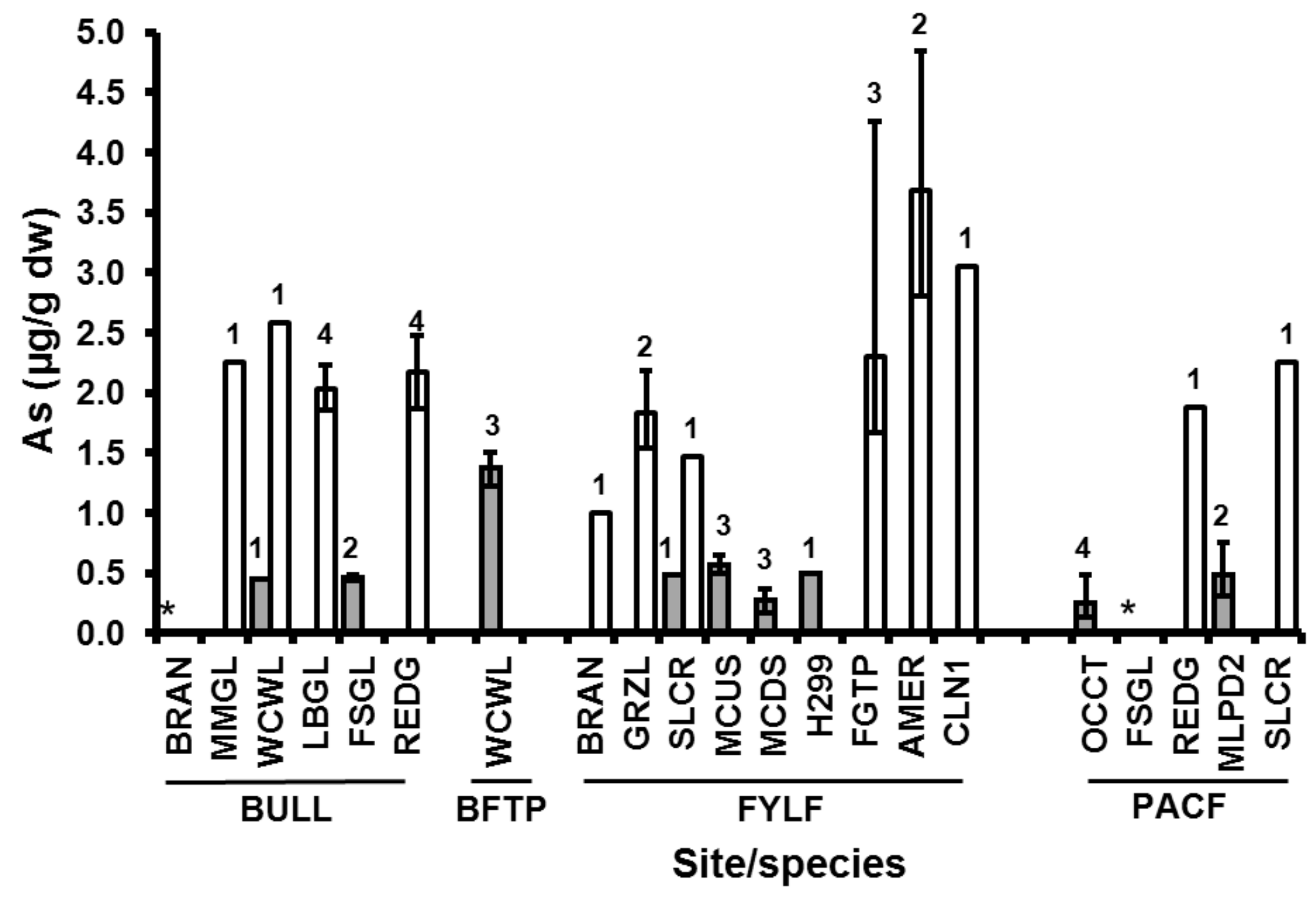

Figure 11. Bar graph showing geometric mean (and range and sample size) of arsenic (As) concentrations (micrograms per gram, dry weight [ $\mu \mathrm{g} / \mathrm{g}$, dw]) in adult bullfrogs (BULL; Lithobates catesbeianus), larval bullfrogs (BFTP), foothill yellow-legged frogs (FYLF; Rana boylii), and Pacific chorus frogs (PACF; Pseudacris regilla) collected from Whiskeytown National Recreation Area and vicinity, northwestern California, 2002 (shaded) and 2003 (clear). No bar means that taxon was not collected (see appendix 5). * means less than detection limit. (See table 1 for definitions of site codes.) 


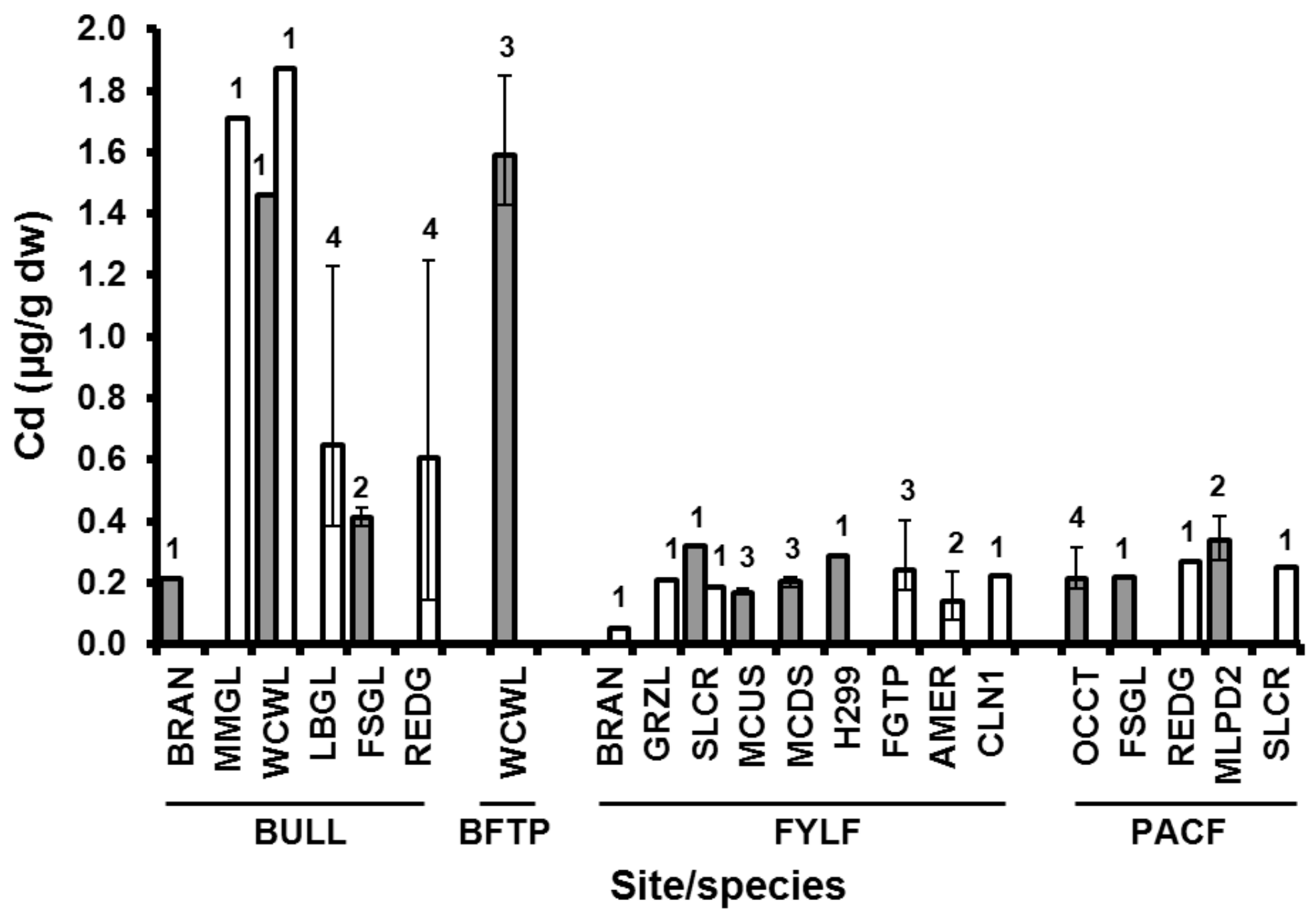

Figure 12. Bar graph showing geometric mean (and range and sample size) of cadmium (Cd) concentrations (micrograms per gram, dry weight [ $\mu \mathrm{g} / \mathrm{g}$, dw]) in adult bullfrogs (BULL; Lithobates catesbeianus), larval bullfrogs (BFTP), foothill yellow-legged frogs (FYLF; Rana boylii), and Pacific chorus frogs (PACF; Pseudacris regilla) collected from Whiskeytown National Recreation Area and vicinity, northwestern California, 2002 (shaded) and 2003 (clear). No bar means that taxon was not collected (see appendix 5). (See table 1 for definitions of site codes.) 


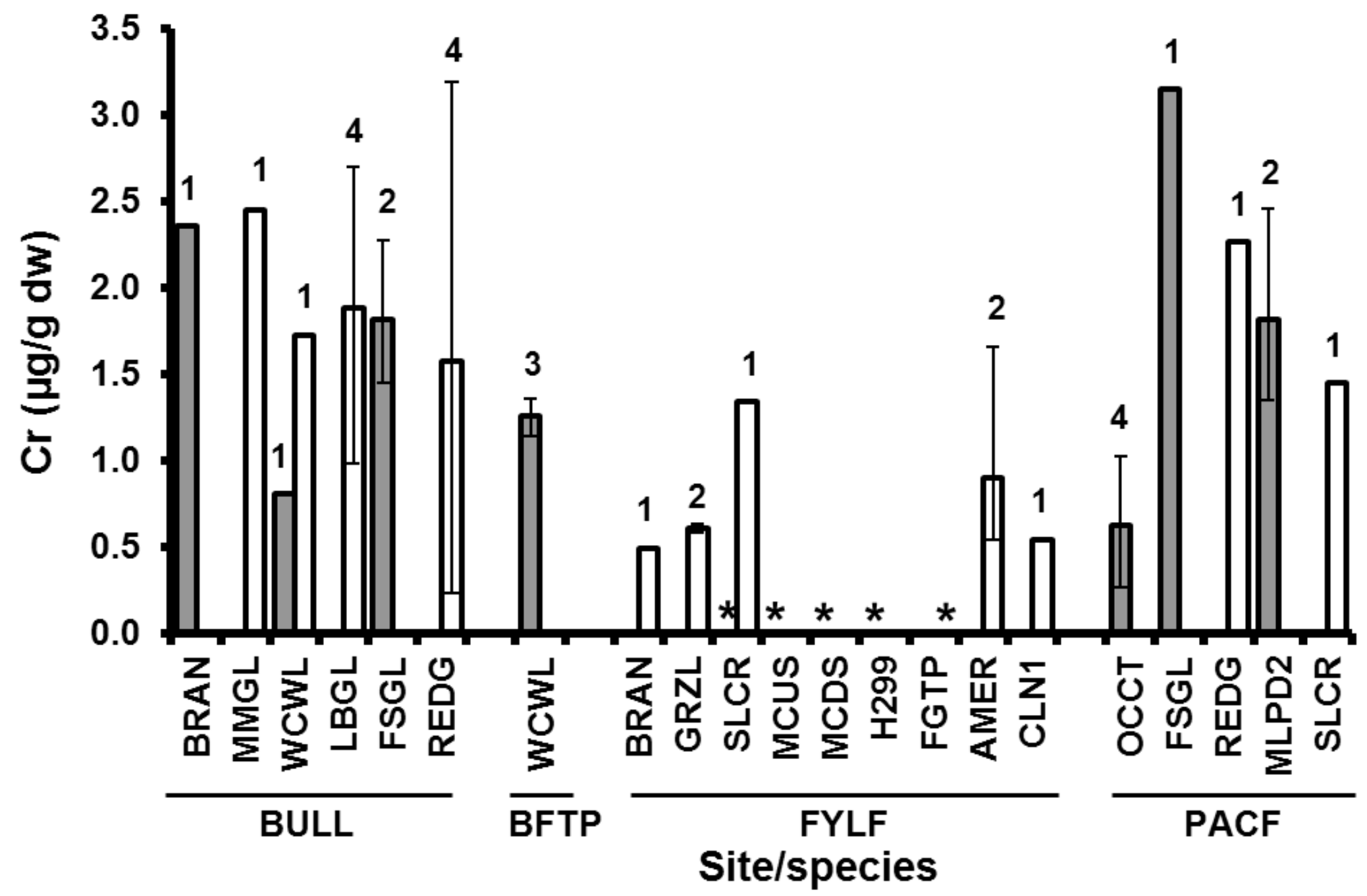

Figure 13. Bar graph showing geometric mean (and range and sample size) of chromium $(\mathrm{Cr})$ concentrations (micrograms per gram, dry weight [ $\mu \mathrm{gg} / \mathrm{g}$, $\mathrm{dw}]$ ) in adult bullfrogs (BULL; Lithobates catesbeianus), larval bullfrogs (BFTP), foothill yellow-legged frogs (FYLF; Rana boylii), and Pacific chorus frogs (PACF; Pseudacris regilla) collected from Whiskeytown National Recreation Area and vicinity, northwestern California, 2002 (shaded) and 2003 (clear). No bar means that taxon was not collected (see appendix 5). * means less than the detection limit. (See table 1 for definitions of site codes.) 


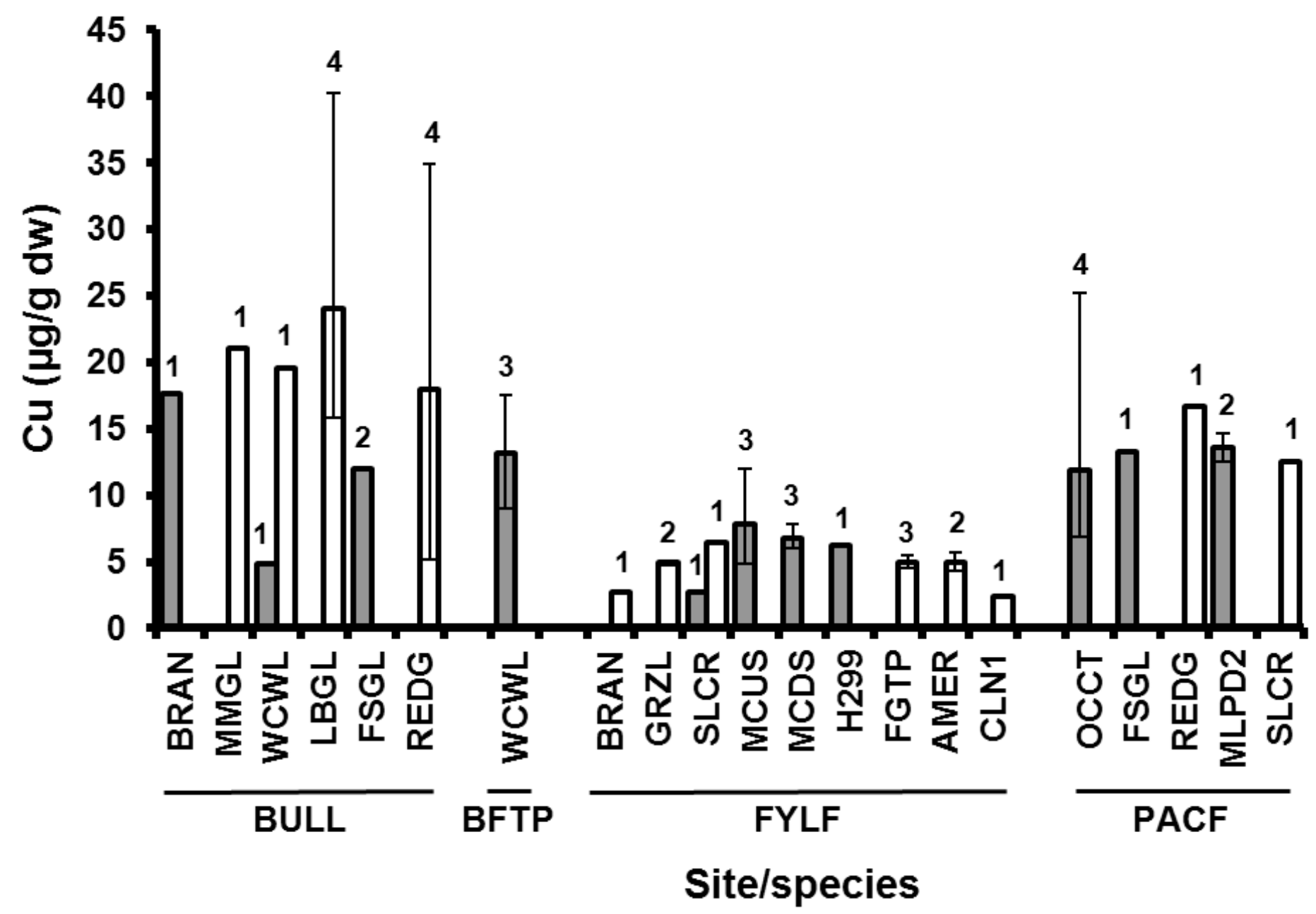

Figure 14. Bar graph showing geometric mean (and range and sample size) of copper $\mathrm{Cu}$ ) concentrations (micrograms per gram, dry weight [ $\mu \mathrm{gg} / \mathrm{g}$, dw]) in adult bullfrogs (BULL; Lithobates catesbeianus), larval bullfrogs (BFTP), foothill yellow-legged frogs (FYLF; Rana boylii), and Pacific chorus frogs (PACF; Pseudacris regilla) collected from Whiskeytown National Recreation Area and vicinity, northwestern California, 2002 (shaded) and 2003 (clear). No bar means that taxon was not collected (see appendix 5). (See table 1 for definitions of site codes.) 


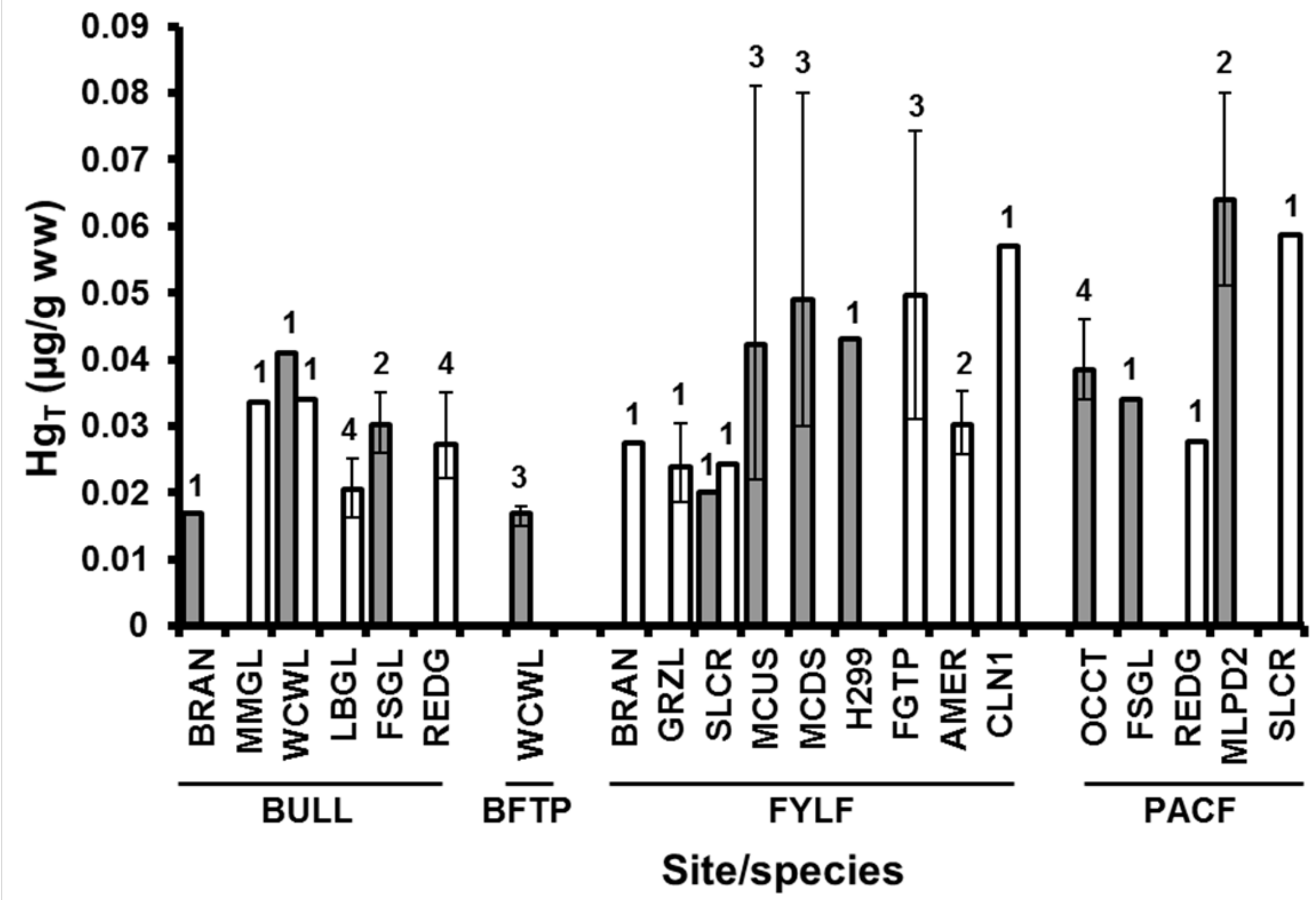

Figure 15. Bar graph showing geometric mean (and range and sample size) of total mercury $\left(\mathrm{Hg}_{\mathrm{T}}\right)$ concentrations (micrograms per gram, wet weight $[\mu \mathrm{g} / \mathrm{g}, \mathrm{ww}])$ in adult bullfrogs (BULL; Lithobates catesbeianus), larval bullfrogs (BFTP), foothill yellow-legged frogs (FYLF; Rana boylii), and Pacific chorus frogs (PACF; Pseudacris regilla) collected from Whiskeytown National Recreation Area and vicinity, northwestern California, 2002 (shaded) and 2003 (clear). No bar means that taxon was not collected (see appendix 5). (See table 1 for definitions of site codes.) 


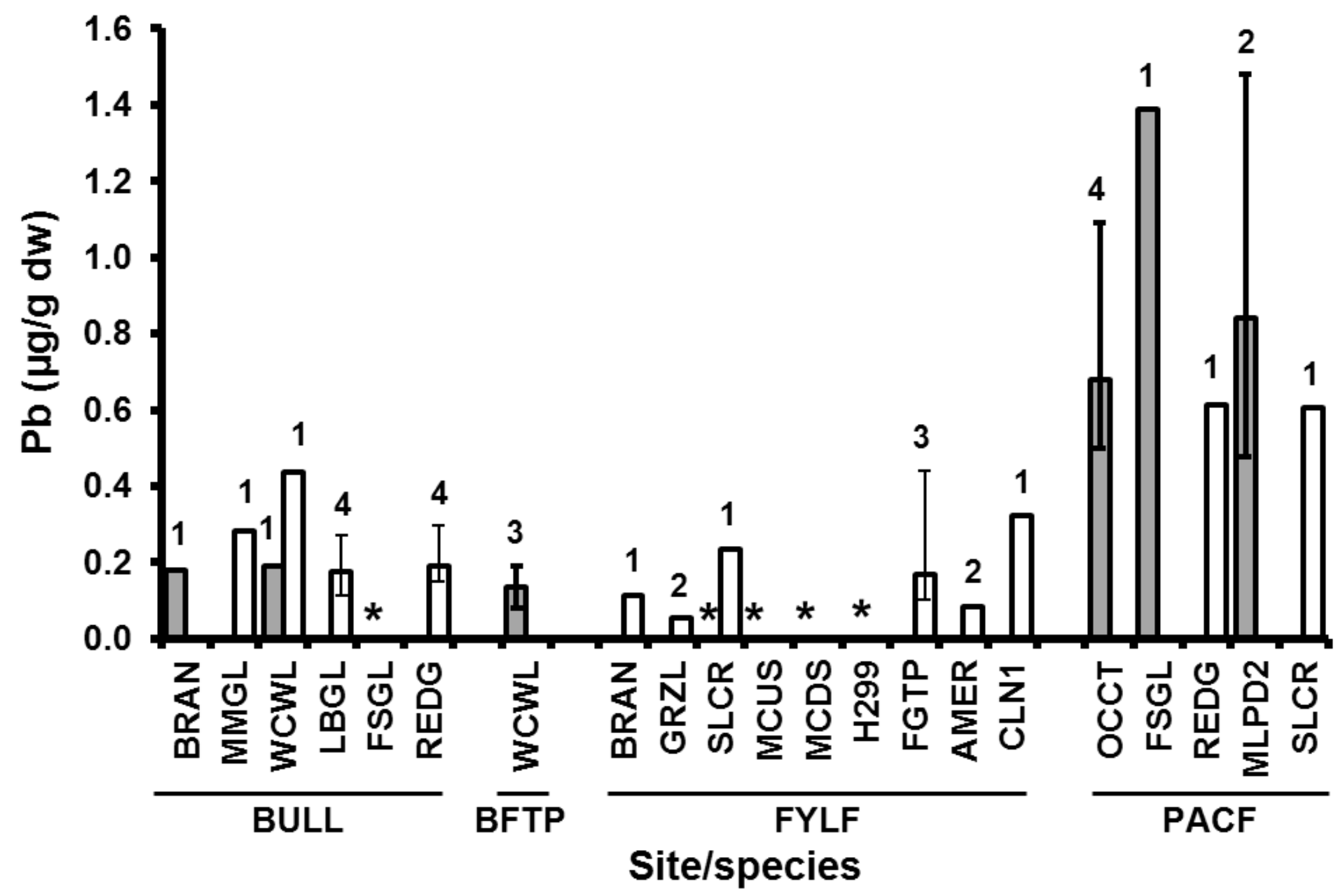

Figure 16. Bar graph showing geometric mean (and range and sample size) of lead $(\mathrm{Pb})$ concentrations (micrograms per gram, dry weight $[\mu \mathrm{g} / \mathrm{g}, \mathrm{dw}]$ ) in adult bullfrogs (BULL; Lithobates catesbeianus), larval bullfrogs (BFTP), foothill yellow-legged frogs (FYLF; Rana boylii), and Pacific chorus frogs (PACF; Pseudacris regilla) collected from Whiskeytown National Recreation Area and vicinity, northwestern California, 2002 (shaded) and 2003 (clear). No bar means that taxon was not collected (see appendix 5). ${ }^{*}$ means less than detection limit. (See table 1 for definitions of site codes.) 


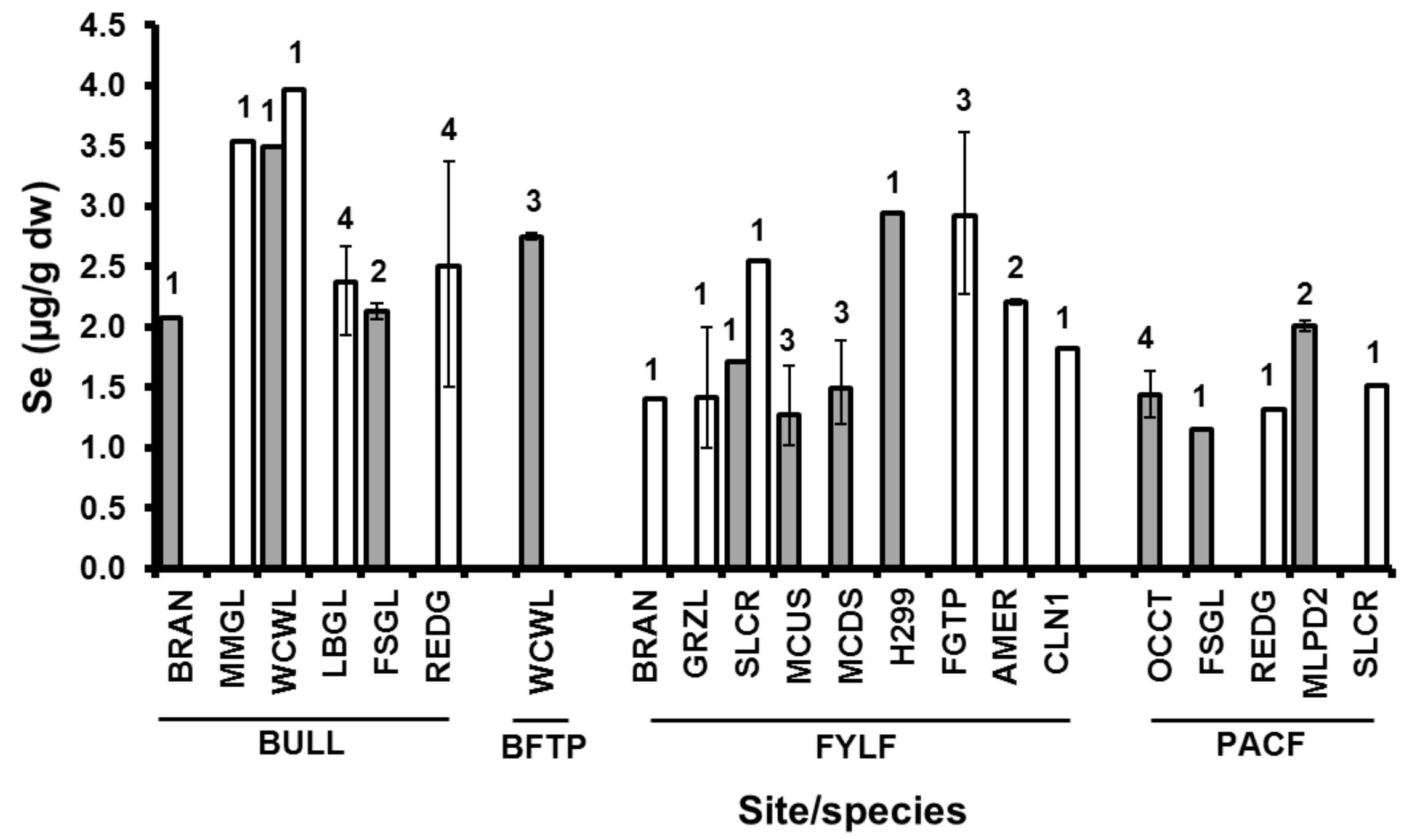

Figure 17. Bar graph showing geometric mean (and range and sample size) of selenium (Se) concentrations (micrograms per gram, dry weight [ $\mu \mathrm{g} / \mathrm{g}$, $\mathrm{dw}]$ ) in adult bullfrogs (BULL; Lithobates catesbeianus), larval bullfrogs (BFTP), foothill yellow-legged frogs (FYLF; Rana boylii), and Pacific chorus frogs (PACF; Pseudacris regilla) collected from Whiskeytown National Recreation Area and vicinity, northwestern California, 2002 (shaded) and 2003 (clear). No bar means that taxon was not collected (see appendix 5). (See table 1 for definitions of site codes.) 


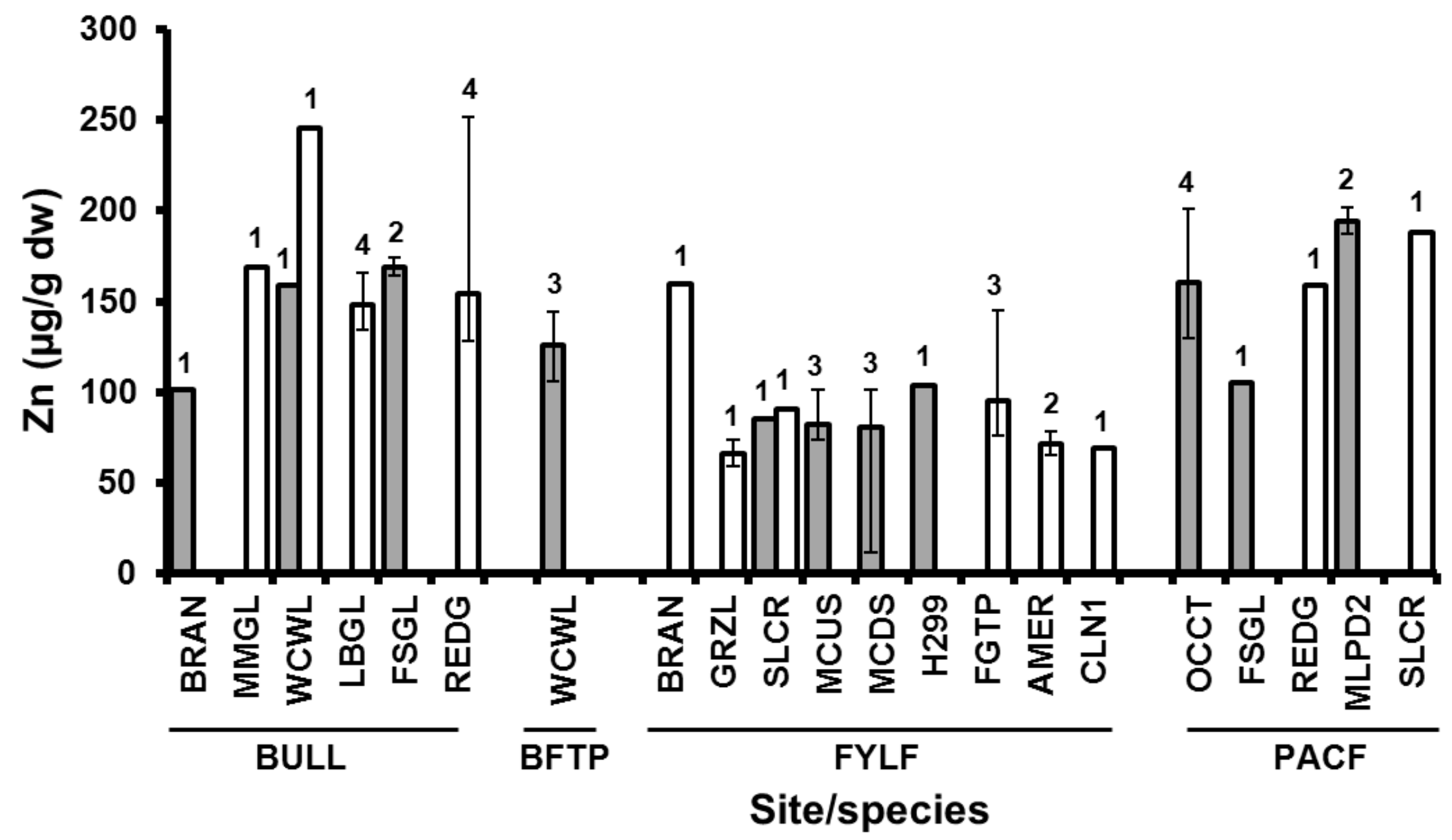

Figure 18. Bar graph showing geometric mean (and range and sample size) of zinc (Zn) concentrations (micrograms per gram, dry weight [ $\mu \mathrm{g} / \mathrm{g}$, dw]) in adult bullfrogs (BULL; Lithobates catesbeianus), larval bullfrogs (BFTP), foothill yellow-legged frogs (FYLF; Rana boylii), and Pacific chorus frogs (PACF; Pseudacris regilla) collected from Whiskeytown National Recreation Area and vicinity, northwestern California, 2002 (shaded) and 2003 (clear). No bar means that taxon was not collected (see appendix 5). (See table 1 for definitions of site codes.) 

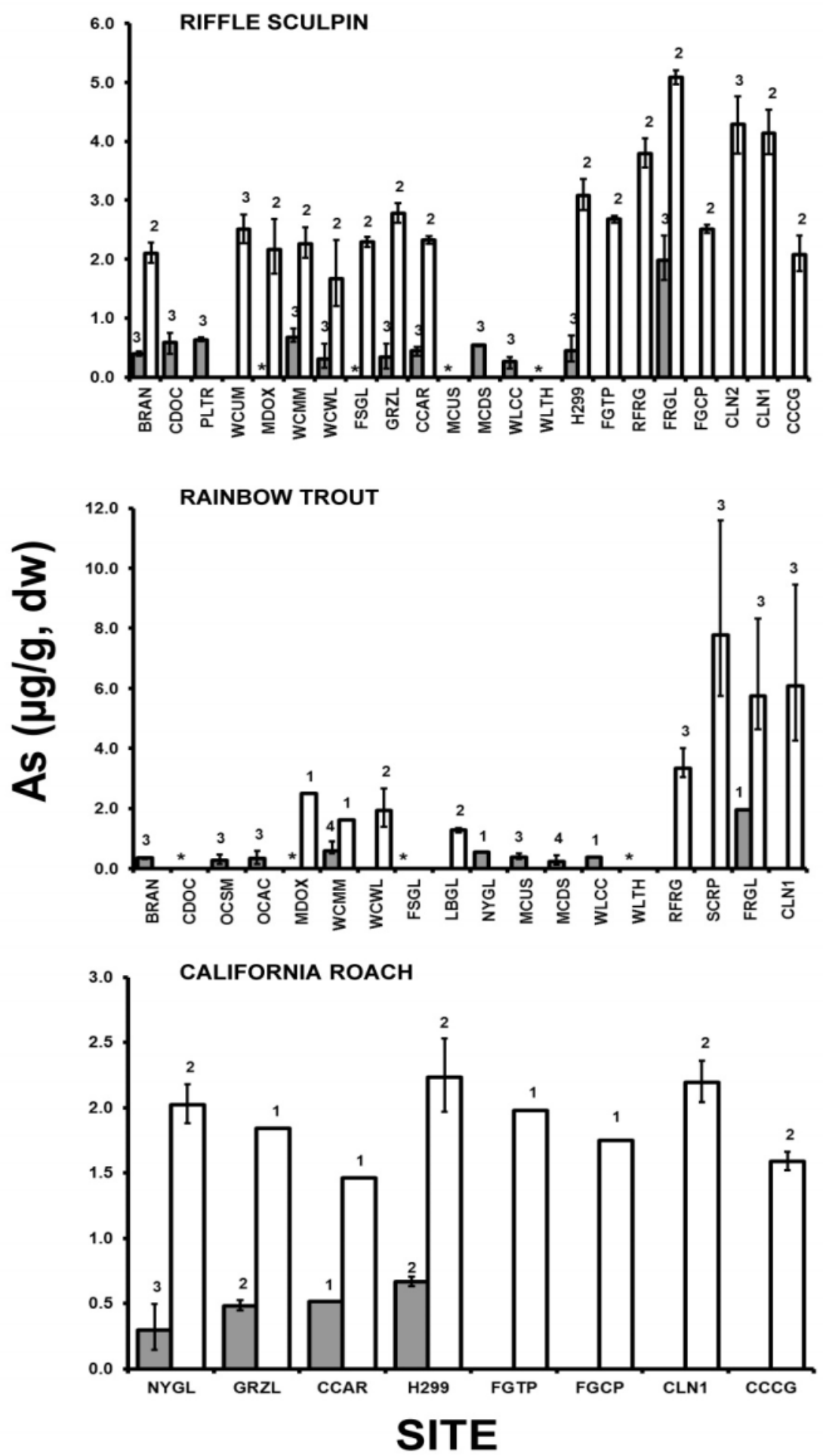

Figure 19. Bar graphs showing geometric mean (and range and sample size) of arsenic (As) concentrations (micrograms per gram, dry weight $[\mu \mathrm{g} / \mathrm{g}, \mathrm{dw}]$ ) in riffle sculpin (Cottus gulosus), rainbow trout (Oncorhynchus mykiss), and California roach (Hesperoleucus symmetricus) collected from Whiskeytown National Recreation Area and vicinity, northwestern California, 2002 (shaded) and 2003 (clear). No bar means that taxon was not collected (see appendix 6). ${ }^{*}$ means less than detection limit. (See table 1 for definitions of site codes.) 

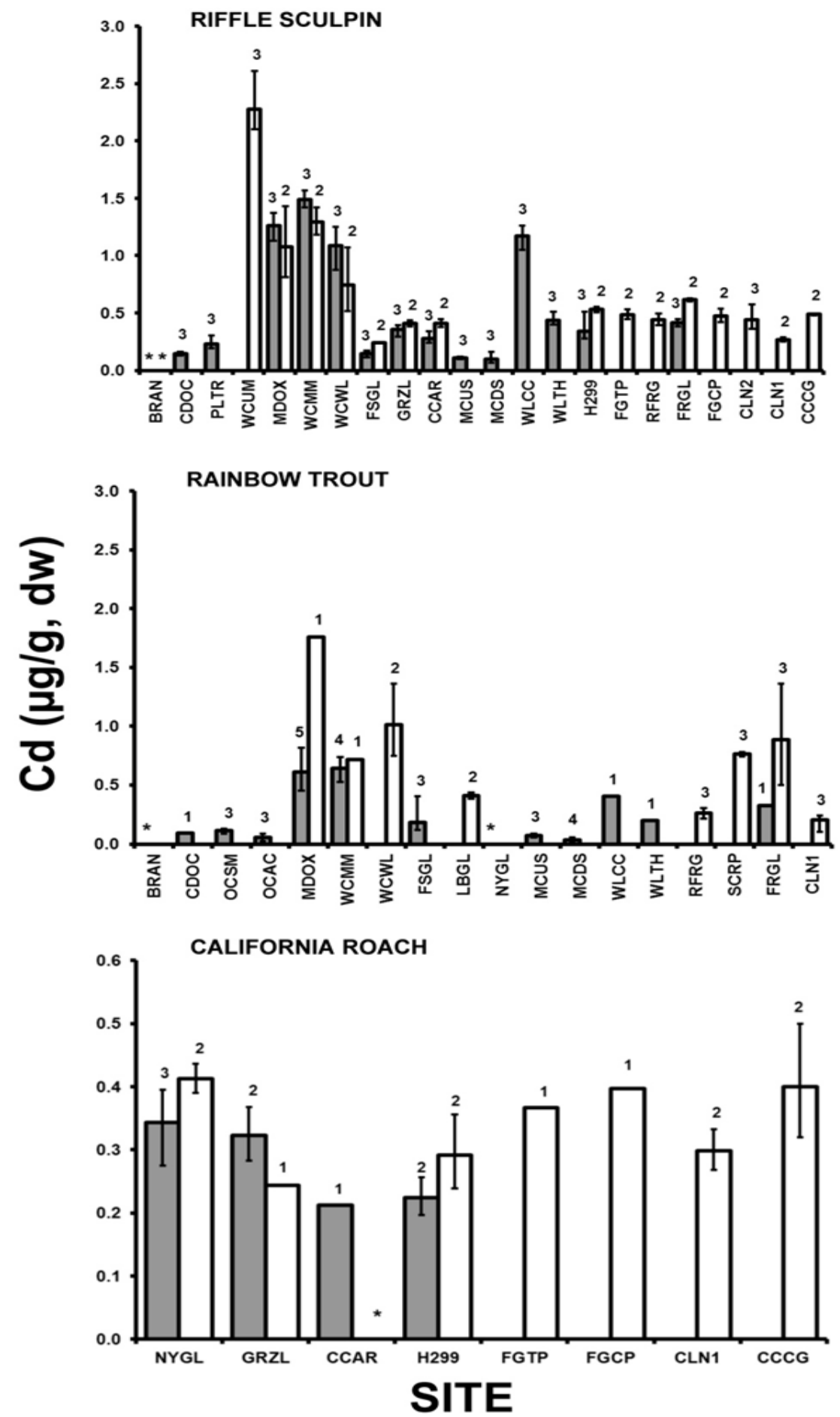

Figure 20. Bar graphs showing geometric mean (and range and sample size) of cadmium (Cd) concentrations (micrograms per gram, dry weight [ $\mathrm{\mu g} / \mathrm{g}, \mathrm{dw}]$ ) in riffle sculpin (Cottus gulosus), rainbow trout (Oncorhynchus mykiss), and California roach (Hesperoleucus symmetricus) collected from Whiskeytown National Recreation Area and vicinity, northwestern California, 2002 (shaded) and 2003 (clear). No bar means that taxon was not collected (see appendix 6). ${ }^{*}$ means less than detection limit. (See table 1 for definitions of site codes.) 

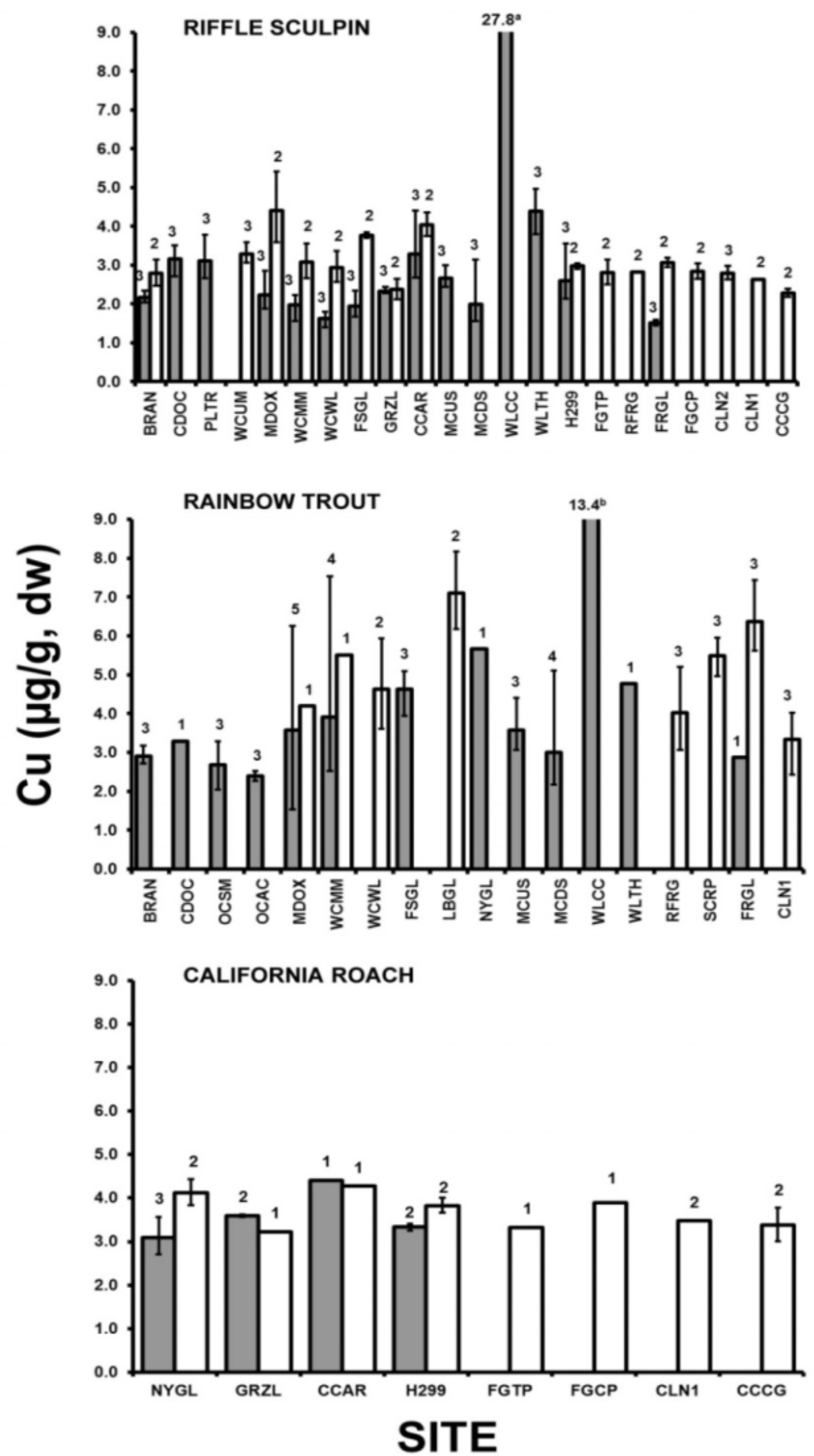

Figure 21. Bar graphs showing geometric mean (and range and sample size) of copper ( $\mathrm{Cu}$ ) concentrations (micrograms per gram, dry weight [ $\mathrm{\mu g} / \mathrm{g}, \mathrm{dw}]$ ) in riffle sculpin (Cottus gulosus), rainbow trout (Oncorhynchus mykiss), and California roach (Hesperoleucus symmetricus) collected from Whiskeytown National Recreation Area and vicinity, northwestern California, 2002 (shaded) and 2003 (clear). No bar means that taxon was not collected (see appendix 6). (See table 1 for definitions of site codes.) The concentration of Cu in sculpin from WLCC in 2002 $(27.8 \mu \mathrm{g} / \mathrm{g}, \mathrm{dw})$ exceeded the range of the graph. The concentration of Cu in trout from WLCC in $2002(13.4 \mu \mathrm{g} / \mathrm{g}$, $\mathrm{dw}$ ) exceeded the range of the graph. 

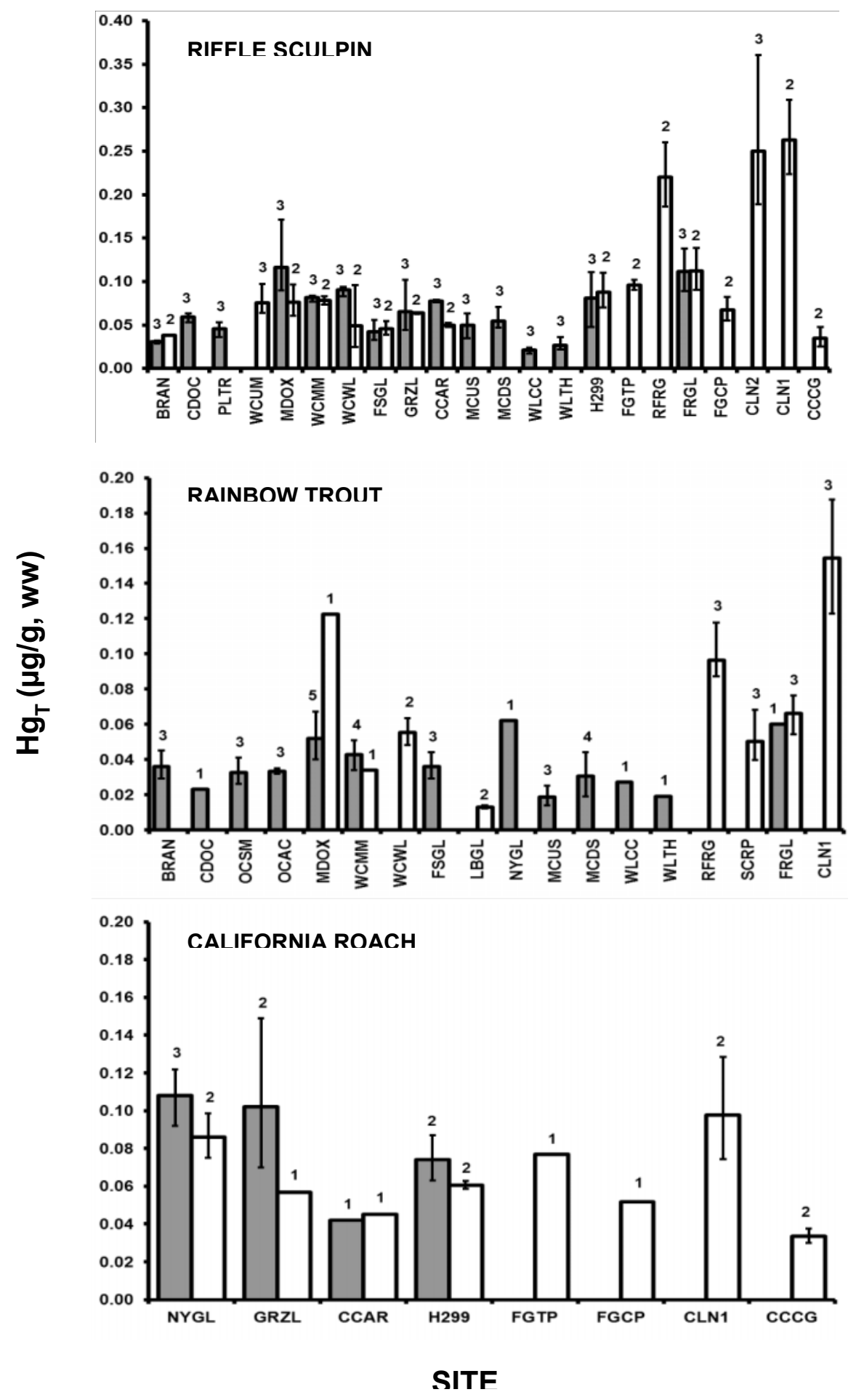

Figure 22. Bar graphs showing geometric mean (and range and sample size) of total mercury ( $\mathrm{Hg}_{\mathrm{T}}$ ) concentrations (micrograms per gram, wet weight $[\mu \mathrm{g} / \mathrm{g}, \mathrm{ww}]$ ) in riffle sculpin (Cottus gulosus), rainbow trout (Oncorhynchus mykiss), and California roach (Hesperoleucus symmetricus) collected from Whiskeytown National Recreation Area and vicinity, northwestern California, 2002 (shaded) and 2003 (clear). No bar means that taxon was not collected (see appendix 6). (See table 1 for definitions of site codes.) 

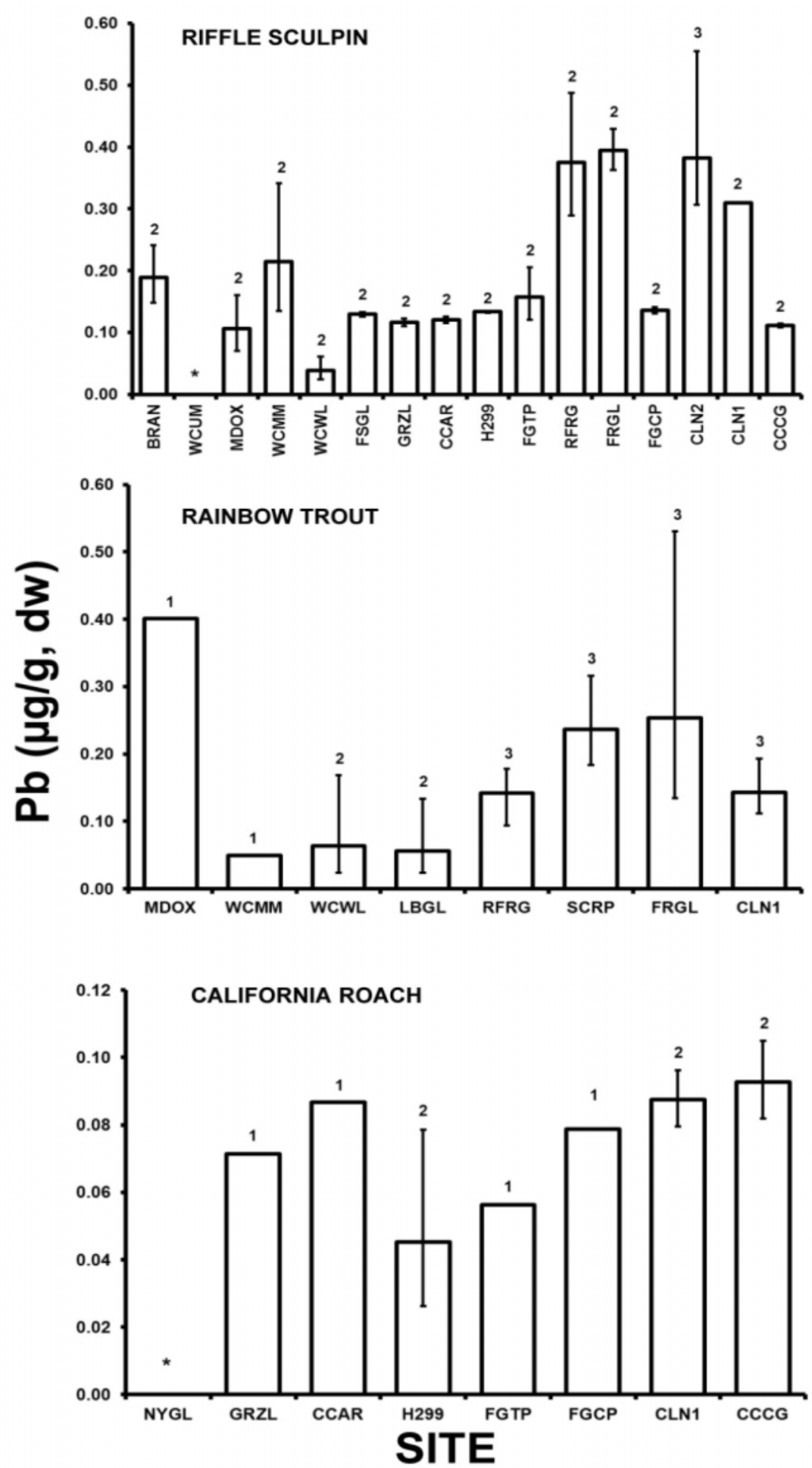

Figure 23. Bar graphs showing geometric mean (and range and sample size) of lead (Pb) concentrations (micrograms per gram, dry weight [ $\mathrm{\mu g} / \mathrm{g}, \mathrm{dw}]$ ) in riffle sculpin (Cottus gulosus), rainbow trout (Oncorhynchus mykiss), and California roach (Hesperoleucus symmetricus) collected from Whiskeytown National Recreation Area and vicinity, northwestern California, 2003. More than 50 percent of the fish collected in 2002 had lead concentrations less than detection limit and are not presented in this graph (see appendix 6). * means less than detection limit. (See table 1 for definitions of site codes.) 

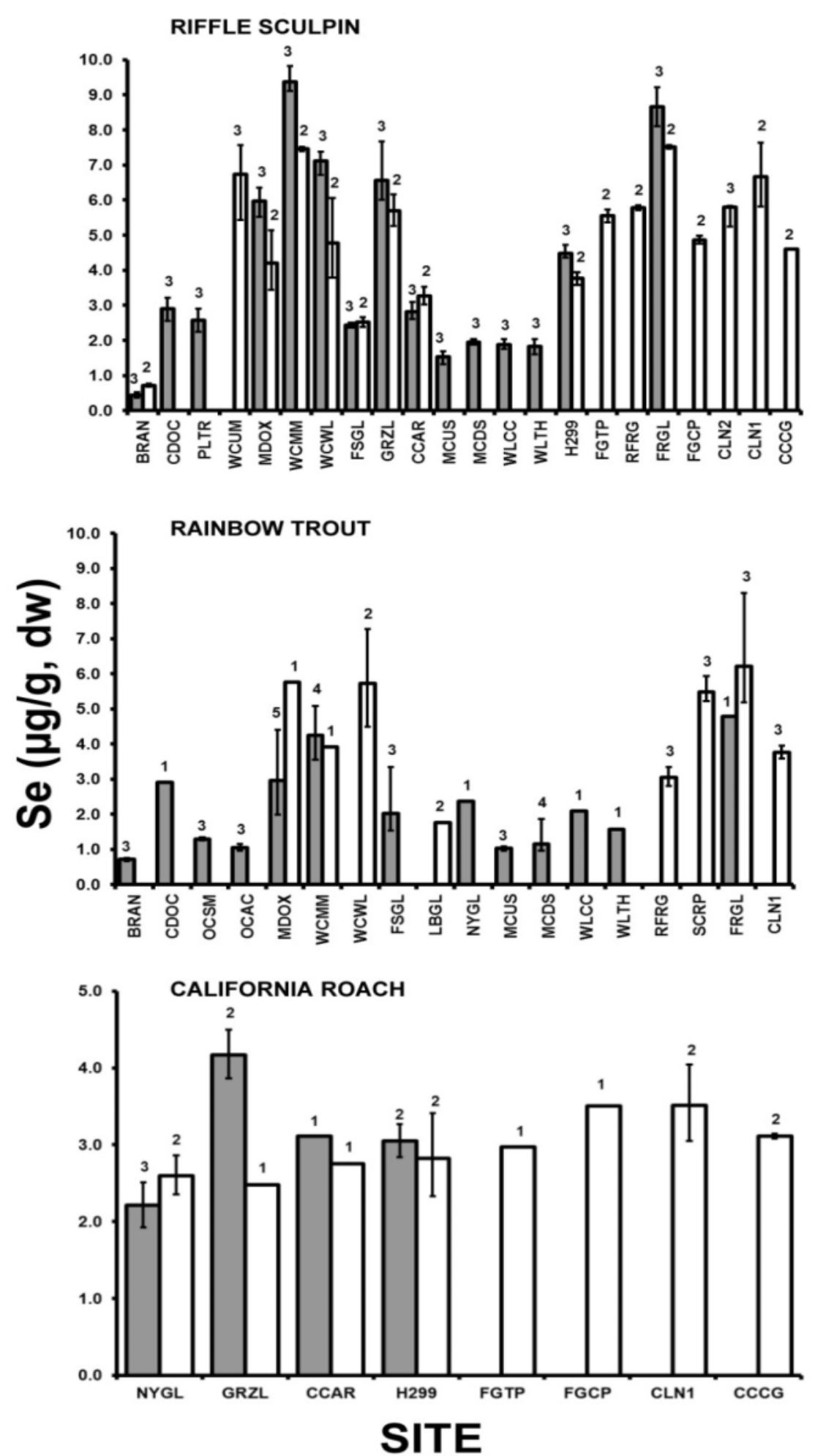

Figure 24. Bar graphs showing geometric mean (and range and sample size) of selenium (Se) concentrations (micrograms per gram, dry weight [ $\mathrm{\mu g} / \mathrm{g}, \mathrm{dw}]$ ) in riffle sculpin (Cottus gulosus), rainbow trout (Oncorhynchus mykiss), and California roach (Hesperoleucus symmetricus) collected from Whiskeytown National Recreation Area and vicinity, northwestern California, 2002 (shaded) and 2003 (clear). No bar means that taxon was not collected (see appendix 6). (See table 1 for definitions of site codes.) 

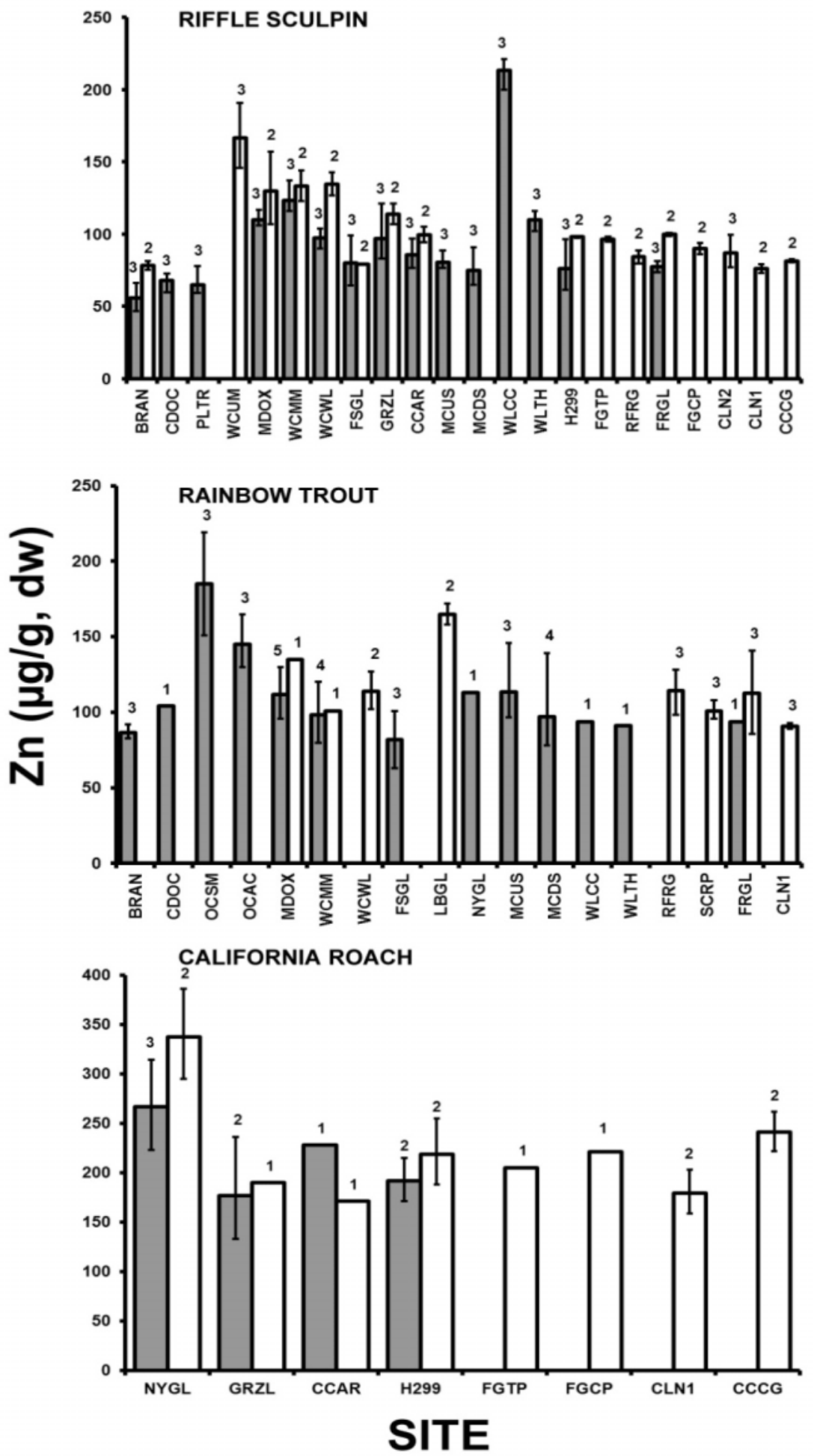

Figure 25. Bar graphs showing geometric mean (and range and sample size) of zinc $(\mathrm{Zn})$ concentrations (micrograms per gram, dry weight [ $\mathrm{\mu g} / \mathrm{g}, \mathrm{dw}]$ ) in riffle sculpin (Cottus gulosus), rainbow trout (Oncorhynchus mykiss), and California roach (Hesperoleucus symmetricus) collected from Whiskeytown National Recreation Area and vicinity, northwestern California, 2002 (shaded) and 2003 (clear). No bar means that taxon was not collected (see appendix 6). (See table 1 for definitions of site codes.) 
Table 1. Sampling sites, locations (NAD 83), sampling dates, and biological samples collected for metals and trace elements analyses in Whiskeytown National Recreation Area and nearby Clear Creek watershed, northwestern California, 2002-03.

[Abbreviations: Cr., Creek; d/s, downstream; no., number; u/s, upstream; , not sampled. Location: Site located within boundaries of Whiskeytown NRA is WHIS; site located in Clear Creek watershed outside boundaries of Whiskeytown NRA is CC. Invertebrates: These were composite samples. Fish: Both individual and composite samples of fish were analyzed. Amphibians: Individual adult or juvenile amphibians were analyzed, except for WCWL in 2002, where three composites of three bullfrog larvae each were also analyzed]

\begin{tabular}{|c|c|c|c|c|c|c|c|c|c|c|c|c|}
\hline \multirow[b]{3}{*}{ Sampling site } & \multirow[b]{3}{*}{ Site code } & \multirow[b]{3}{*}{ Location } & \multirow[b]{3}{*}{ Latitude } & \multirow[b]{3}{*}{ Longitude } & \multirow{2}{*}{\multicolumn{2}{|c|}{ Collection dates }} & \multicolumn{6}{|c|}{ Samples collected } \\
\hline & & & & & & & \multicolumn{2}{|c|}{ Invertebrates } & \multicolumn{2}{|c|}{ Fish } & \multicolumn{2}{|c|}{ Amphibians } \\
\hline & & & & & 2002 & 2003 & 2002 & 2003 & 2002 & 2003 & 2002 & 2003 \\
\hline Clear Cr. d/s Orofino Gulch & CDOC & WHIS & $40^{\circ} 34^{\prime} 41^{\prime \prime} \mathrm{N}$ & $122^{\circ} 32^{\prime} 13^{\prime \prime} \mathrm{W}$ & 5-Jun, 18-Jun & - & 4 & - & 4 & - & 0 & - \\
\hline Orofino Gulch u/s Clear Cr. & OCAC & WHIS & $40^{\circ} 34^{\prime} 45^{\prime \prime} \mathrm{N}$ & $122^{\circ} 32^{\prime} 13^{\prime \prime} \mathrm{W}$ & 4-Jun & - & 3 & - & 3 & - & 0 & - \\
\hline Orofino Gulch $\mathrm{d} / \mathrm{s}$ lower stamp mill & OCSM & WHIS & $40^{\circ} 34^{\prime} 52^{\prime \prime} \mathrm{N}$ & $122^{\circ} 31^{\prime} 52^{\prime \prime} \mathrm{W}$ & 16-Apr & - & 4 & - & 3 & - & 0 & - \\
\hline Orofino Gulch at canal trail & OCCT & WHIS & $40^{\circ} 34^{\prime} 54^{\prime \prime} \mathrm{N}$ & $122^{\circ} 31^{\prime} 39^{\prime \prime} \mathrm{W}$ & 16-Apr, 18-Jun & - & 4 & - & 0 & - & 4 & - \\
\hline Clear Cr. u/s Peltier Rd. & PLTR & WHIS & $40^{\circ} 35^{\prime} 11^{\prime \prime} \mathrm{N}$ & $122^{\circ} 33^{\prime} 01^{\prime \prime} \mathrm{W}$ & 6-Jun, 19-Jun & - & 3 & - & 3 & - & 0 & - \\
\hline Mill Cr. u/s El Dorado Mine & MCUS & WHIS & $40^{\circ} 39^{\prime} 29^{\prime \prime} \mathrm{N}$ & $122^{\circ} 38^{\prime} 18^{\prime \prime} \mathrm{W}$ & 12-Jun & - & 4 & - & 6 & - & 3 & - \\
\hline Mill Cr. d/s El Dorado Mine & MCDS & WHIS & $40^{\circ} 39^{\prime} 35^{\prime \prime} \mathrm{N}$ & $122^{\circ} 38^{\prime} 13^{\prime \prime} \mathrm{W}$ & 12-Jun & - & 5 & - & 7 & - & 3 & - \\
\hline Mill Pond no. 1 near Merry Mountain & MLPD1 & WHIS & $40^{\circ} 39^{\prime} 48^{\prime \prime} \mathrm{N}$ & $122^{\circ} 37^{\prime} 48^{\prime \prime} \mathrm{W}$ & 16-Apr & - & 1 & - & 0 & - & 0 & - \\
\hline Mill Pond no. 2 near Merry Mountain & MLPD2 & WHIS & $40^{\circ} 39^{\prime} 49^{\prime \prime} \mathrm{N}$ & $122^{\circ} 37^{\prime} 48^{\prime \prime} \mathrm{W}$ & 16-Apr & - & 1 & - & 0 & - & 2 & - \\
\hline Willow Cr. at Tower House & WLTH & WHIS & $40^{\circ} 39^{\prime} 50^{\prime \prime} \mathrm{N}$ & $122^{\circ} 38^{\prime} 13^{\prime \prime} \mathrm{W}$ & 13-Jun & - & 3 & - & 4 & - & 0 & - \\
\hline Willow Cr. u/s Crystal Cr. & WLCC & WHIS & $40^{\circ} 40^{\prime} 16^{\prime \prime} \mathrm{N}$ & $122^{\circ} 38^{\prime} 57^{\prime \prime} \mathrm{W}$ & 19-Jun & - & 3 & - & 4 & - & 0 & - \\
\hline Brandy Cr. near South Shore Dr. & BRAN & WHIS & $40^{\circ} 36^{\prime} 40^{\prime \prime} \mathrm{N}$ & $122^{\circ} 34^{\prime} 36^{\prime \prime} \mathrm{W}$ & 5-Jun & 5-Jun & 9 & 7 & 6 & 2 & 1 & 1 \\
\hline New York Gulch u/s Highway 299 & NYGL & WHIS & $40^{\circ} 38^{\prime} 54^{\prime \prime} \mathrm{N}$ & $122^{\circ} 34^{\prime} 33^{\prime \prime} \mathrm{W}$ & 16-Apr, 11-Jun & 30-May & 7 & 5 & 4 & 2 & 0 & 0 \\
\hline Foster's Gulch near road & FSGL & WHIS & $40^{\circ} 39^{\prime} 10^{\prime \prime} \mathrm{N}$ & $122^{\circ} 33^{\prime} 08^{\prime \prime} \mathrm{W}$ & 16-Apr, 19-Jun & 22-May & 5 & 7 & 6 & 2 & 3 & 0 \\
\hline Whiskey Cr. u/s Whiskeytown Lake & WCWL & WHIS & $40^{\circ} 39^{\prime} 23^{\prime \prime} \mathrm{N}$ & $122^{\circ} 33^{\prime} 35^{\prime \prime} \mathrm{W}$ & 18-Jun & 4-Jun & 5 & 7 & 3 & 4 & 4 & 1 \\
\hline Clear Cr. u/s Carr Powerhouse & CCAR & WHIS & $40^{\circ} 39^{\prime} 36^{\prime \prime} \mathrm{N}$ & $122^{\circ} 37^{\prime} 43^{\prime \prime} \mathrm{W}$ & 19-Jun & 30-May & 5 & 6 & 4 & 3 & 0 & 0 \\
\hline Grizzly Cr. near old bridge & GRZL & WHIS & $40^{\circ} 39^{\prime} 36^{\prime \prime} \mathrm{N}$ & $122^{\circ} 35^{\prime} 58^{\prime \prime} \mathrm{W}$ & 11-Jun & 30-May & 5 & 5 & 5 & 3 & 0 & 2 \\
\hline Slate Cr. d/s waterfall & SLCR & WHIS & $40^{\circ} 39^{\prime} 46^{\prime \prime} \mathrm{N}$ & $122^{\circ} 37^{\prime} 41^{\prime \prime} \mathrm{W}$ & 5-Jun, 12-Jun & 28-May & 6 & 6 & 0 & 0 & 1 & 2 \\
\hline Clear Cr. u/s Highway 299 & H299 & WHIS & $40^{\circ} 39^{\prime} 58^{\prime \prime} \mathrm{N}$ & $122^{\circ} 37^{\prime} 56^{\prime \prime} \mathrm{W}$ & 13-Jun & 29-May & 3 & 5 & 5 & 4 & 1 & 0 \\
\hline Whiskey Cr. d/s Mad Mule Gulch & WCMM & $\mathrm{CC}$ & $40^{\circ} 40^{\prime} 13^{\prime \prime} \mathrm{N}$ & $122^{\circ} 33^{\prime} 56^{\prime \prime} \mathrm{W}$ & 11-Jun & 4-Jun & 5 & 4 & 7 & 3 & 0 & 0 \\
\hline Mad Ox Gulch u/s Whiskey Cr. & MDOX & $\mathrm{CC}$ & $40^{\circ} 40^{\prime} 46^{\prime \prime} \mathrm{N}$ & $122^{\circ} 33^{\prime} 48^{\prime \prime} \mathrm{W}$ & 6-Jun & 23-May & 7 & 6 & 8 & 3 & 0 & 0 \\
\hline French Gulch u/s Clear Cr. & FRGL & $\mathrm{CC}$ & $40^{\circ} 42^{\prime} 16^{\prime \prime} \mathrm{N}$ & $122^{\circ} 39^{\prime} 04^{\prime \prime} \mathrm{W}$ & 18-Jun & 28-May & 5 & 5 & 4 & 5 & 0 & 0 \\
\hline Red Gulch near picnic area & REDG & WHIS & $40^{\circ} 38^{\prime} 52^{\prime \prime} \mathrm{N}$ & $122^{\circ} 33^{\prime} 01^{\prime \prime} \mathrm{W}$ & - & 21-May & - & 4 & - & 0 & - & 5 \\
\hline Liberty Gulch d/s road & LBGL & WHIS & $40^{\circ} 39^{\prime} 14^{\prime \prime} \mathrm{N}$ & $122^{\circ} 33^{\prime} 13^{\prime \prime} \mathrm{W}$ & - & 4-Jun & - & 6 & - & 2 & - & 4 \\
\hline Mad Mule Gulch u/s Whiskey Cr. & MMGL & $\mathrm{CC}$ & $40^{\circ} 40^{\prime} 22^{\prime \prime} \mathrm{N}$ & $122^{\circ} 34^{\prime} 10^{\prime \prime} \mathrm{W}$ & - & 4-Jun & - & 5 & - & 0 & - & 1 \\
\hline Whiskey Cr. u/s Mad Ox Gulch & WCUM & $\mathrm{CC}$ & $40^{\circ} 40^{\prime} 49^{\prime \prime} \mathrm{N}$ & $122^{\circ} 33^{\prime} 52^{\prime \prime} \mathrm{W}$ & - & 23-May & - & 6 & - & 3 & - & 0 \\
\hline Mad Ox Mine outlet & MOXO & $\mathrm{CC}$ & $40^{\circ} 41^{\prime} 01^{\prime \prime} \mathrm{N}$ & $122^{\circ} 33^{\prime} 20^{\prime \prime} \mathrm{W}$ & - & 23-May & - & 5 & - & 0 & - & 0 \\
\hline Mad Ox Gulch u/s Mad Ox Mine & MXUS & $\mathrm{CC}$ & $40^{\circ} 41^{\prime} 10^{\prime \prime} \mathrm{N}$ & $122^{\circ} 33^{\prime} 18^{\prime \prime} \mathrm{W}$ & - & 23-May & - & 7 & - & 0 & - & 0 \\
\hline Clear Cr. at French Gulch trailer park & FGTP & $\mathrm{CC}$ & $40^{\circ} 41^{\prime} 26^{\prime \prime} \mathrm{N}$ & $122^{\circ} 38^{\prime} 24^{\prime \prime} \mathrm{W}$ & - & 29-May & - & 4 & - & 3 & - & 3 \\
\hline Clear Cr. at French Gulch County Park & FGCP & $\mathrm{CC}$ & $40^{\circ} 42^{\prime} 32^{\prime \prime} \mathrm{N}$ & $122^{\circ} 38^{\prime} 13^{\prime \prime} \mathrm{W}$ & - & 29-May & - & 4 & - & 3 & - & 0 \\
\hline Cline Gulch $\mathrm{u} / \mathrm{s}$ China Gulch & CLN2 & $\mathrm{CC}$ & $40^{\circ} 42^{\prime} 43^{\prime \prime} \mathrm{N}$ & $122^{\circ} 36^{\prime} 25^{\prime \prime} \mathrm{W}$ & - & 22-May & - & 6 & - & 3 & - & 0 \\
\hline Scorpion Gulch u/s French Gulch & SCRP & $\mathrm{CC}$ & $40^{\circ} 42^{\prime} 50^{\prime \prime} \mathrm{N}$ & $122^{\circ} 40^{\prime} 23^{\prime \prime} \mathrm{W}$ & - & 27-May & - & 9 & - & 3 & - & 0 \\
\hline American Mine (China Gulch) & AMER & $\mathrm{CC}$ & $40^{\circ} 42^{\prime} 50^{\prime \prime} \mathrm{N}$ & $122^{\circ} 36^{\prime} 58^{\prime \prime} \mathrm{W}$ & - & 22-May & - & 5 & - & 0 & - & 2 \\
\hline Cline Gulch u/s Clear Cr. at bridge & CLN1 & $\mathrm{CC}$ & $40^{\circ} 42^{\prime} 54^{\prime \prime} \mathrm{N}$ & $122^{\circ} 37^{\prime} 40^{\prime \prime} \mathrm{W}$ & - & 28-May & - & 5 & - & 7 & - & 1 \\
\hline Right Fork u/s French Gulch & RFRG & $\mathrm{CC}$ & $40^{\circ} 42^{\prime} 57^{\prime \prime} \mathrm{N}$ & $122^{\circ} 40^{\prime} 12^{\prime \prime} \mathrm{W}$ & - & 29-May & - & 5 & - & 5 & - & 0 \\
\hline Clear Cr. u/s Cline Gulch & CCCG & $\mathrm{CC}$ & $40^{\circ} 43^{\prime} 02^{\prime \prime} \mathrm{N}$ & $122^{\circ} 37^{\prime} 45^{\prime \prime} \mathrm{W}$ & - & 28-May & - & 6 & - & 4 & - & 0 \\
\hline
\end{tabular}


Table 2. Community parameters calculated for samples collected from sites in the Whiskeytown National Recreation Area and nearby Clear Creek watershed, northwestern California, 2002.

[Samples were collected using a modified California Stream Bioassessment Procedure (CSBP); 300 individual organisms were identified and counted from a 3square-feet area. Site: See table 1 for description and location of sites. IBI: Index of Biotic Integrity (IBI) scores standardized to 100 percent (see section, "Study Area and Methods"). Condition: Condition categories are based on northern California IBI (Rehn and others, 2005), and are for comparison purposes only and do not constitute water-quality criteria. Abbreviation: EPT, Ephemeroptera, Plecoptera, and Trichoptera]

\begin{tabular}{|c|c|c|c|c|c|c|c|c|c|c|c|c|}
\hline $\begin{array}{c}\text { Waterbody } \\
\text { name }\end{array}$ & Site & Date & $\begin{array}{c}\text { EPT } \\
\text { richness } \\
\text { (number) }\end{array}$ & $\begin{array}{l}\text { Coleoptera } \\
\text { richness } \\
\text { (number) }\end{array}$ & $\begin{array}{l}\text { Diptera } \\
\text { richness } \\
\text { (number) }\end{array}$ & $\begin{array}{l}\text { Intolerant } \\
\text { individuals } \\
\text { (percent) }\end{array}$ & $\begin{array}{c}\text { Non-insect } \\
\text { taxa } \\
\text { (percent) }\end{array}$ & $\begin{array}{l}\text { Predator } \\
\text { taxa } \\
\text { (percent) }\end{array}$ & $\begin{array}{c}\text { Non- } \\
\text { Gastropoda } \\
\text { scrapers } \\
\text { (percent) }\end{array}$ & $\begin{array}{c}\text { Shredder } \\
\text { taxa } \\
\text { (percent) }\end{array}$ & $|\mathrm{B}|$ & Condition \\
\hline Orofino Creek & OCSM & $06-04-2002$ & 4 & 1 & 4 & 17 & 0 & 1 & 1 & 10 & 35.00 & Poor \\
\hline Orofino Creek & OCAC & 06-04-2002 & 7 & 0 & 7 & 23 & 11 & 6 & 0 & 11 & 46.25 & Fair \\
\hline Orofino Creek & OCCT & 06-04-2002 & 4 & 3 & 7 & 13 & 12 & 3 & 3 & 12 & 46.25 & Fair \\
\hline Clear Creek & $\mathrm{CDOC}$ & $06-05-2002$ & 14 & 1 & 2 & 37 & 15 & 4 & 24 & 5 & 52.50 & Fair \\
\hline Clear Creek & CCAR & 06-19-2002 & 17 & 3 & 4 & 11 & 7 & 9 & 13 & 0 & 52.50 & Fair \\
\hline Clear Creek & PLTR & 06-06-2002 & 16 & 0 & 4 & 38 & 17 & 13 & 14 & 4 & 57.50 & Fair \\
\hline Willow Creek & WLTH & 06-13-2002 & 12 & 4 & 8 & 12 & 14 & 12 & 12 & 3 & 57.50 & Fair \\
\hline Foster Gulch & FSGL & 06-07-2002 & 14 & 4 & 3 & 18 & 15 & 13 & 7 & 12 & 58.75 & Fair \\
\hline New York Gulch & NYGL & 06-112002 & 18 & 5 & 11 & 20 & 10 & 20 & 30 & 2 & 60.00 & Fair \\
\hline Mill Creek & MCDS & $06-12-2002$ & 15 & 7 & 5 & 17 & 18 & 8 & 15 & 3 & 61.25 & Good \\
\hline Whiskey Creek & WCWL & $06-18-2002$ & 16 & 4 & 7 & 15 & 20 & 14 & 16 & 9 & 63.75 & Good \\
\hline Clear Creek & H299 & $06-13-2002$ & 20 & 4 & 3 & 20 & 10 & 7 & 24 & 10 & 65.00 & Good \\
\hline French Gulch Creek & FRGL & $06-18-2002$ & 14 & 4 & 5 & 16 & 23 & 11 & 47 & 10 & 67.50 & Good \\
\hline Mad Ox Gulch & MDOX & $06-06-2002$ & 19 & 4 & 5 & 30 & 19 & 10 & 23 & 8 & 70.00 & Good \\
\hline Brandy Creek & BRAN & $06-05-2002$ & 18 & 6 & 4 & 33 & 7 & 5 & 32 & 7 & 71.25 & Good \\
\hline Mill Creek & MCUS & $06-12-2002$ & 15 & 6 & 6 & 21 & 12 & 11 & 20 & 6 & 71.25 & Good \\
\hline Willow Creek & WLCC & 06-19-2002 & 15 & 2 & 11 & 25 & 19 & 27 & 17 & 8 & 71.25 & Good \\
\hline Grizzly Gulch & GRZL & $06-11-2002$ & 16 & 3 & 5 & 21 & 25 & 10 & 21 & 6 & 75.00 & Good \\
\hline Whiskey Creek & WCMM & $06-11-2002$ & 17 & 6 & 4 & 25 & 12 & 19 & 15 & 16 & 80.00 & Good \\
\hline
\end{tabular}


Table 3. Summary of quality assurance/quality control results from Trace Element Research Laboratory, for samples collected from Whiskeytown National Recreation Area and nearby Clear Creek watershed, northwestern California, 2002-03.

[Inductively coupled plasma: Includes mass spectroscopy and optical emission spectroscopy. Atomic absorption spectroscopy: Includes cold vapor, graphite furnace, and atomic fluorescence. Total: Two to seven tests were run for each metal per year, depending on the number of analyses run per sample type. Blanks: Levels of lead in blanks from 2002 invertebrates were low, but should have no effect on data interpretation. Spikes: Chromium and nickel spikes were high in 2002 invertebrates. Spikes of aluminum, iron, and manganese from sample WH02-037, a fish from 2002, were high. Al spikes were high in 2003 invertebrate samples. This should have no effect on data interpretation. Duplicates: Lead in duplicates from 2002 invertebrates was highly variability, but this should have no effect on data. Variability in duplicates of a fish (WHO2-001) from 2002 was high, possibly owing to lack of homogeneity of the sample. High variability also was observed in 2003 invertebrate samples for iron and manganese. Standard Reference Materials (SRMs): Recovery of arsenic from SRM was low in samples of fish/frogs from 2002; this should not affect data interpretation. Abbreviation: MDL, method detection limit.]

\begin{tabular}{|c|c|c|c|c|c|c|c|c|}
\hline & \multicolumn{3}{|c|}{ Inductively coupled plasma } & \multicolumn{3}{|c|}{ Atomic absorption spectroscopy } & \multirow[b]{2}{*}{ Total } & \multirow{2}{*}{$\begin{array}{l}\text { Percent } \\
\text { acceptable }\end{array}$} \\
\hline & No. & $\begin{array}{c}\text { Acceptable } \\
\text { criteria } \\
\text { (percent) }\end{array}$ & $\begin{array}{c}\text { Percent } \\
\text { acceptable }\end{array}$ & No. & $\begin{array}{c}\text { Acceptable } \\
\text { criteria } \\
\text { (percent) }\end{array}$ & $\begin{array}{c}\text { Percent } \\
\text { acceptable }\end{array}$ & & \\
\hline Blanks & 533 & $<2 \mathrm{x}$ the MDL & 92.1 & 79 & $<2 \mathrm{x}$ the MDL & 97.5 & 612 & 92.8 \\
\hline Spikes & 530 & $80-120$ & 90.7 & 82 & $85-115$ & 89.9 & 612 & 90.5 \\
\hline Duplicates & 533 & $<30$ & 95.7 & 79 & $<20$ & 92.4 & 612 & 95.3 \\
\hline $\begin{array}{l}\text { Standard Reference } \\
\text { Materials }\end{array}$ & 126 & $8-120$ & 78.6 & 41 & $85-115$ & 73.2 & 167 & 77.3 \\
\hline
\end{tabular}


Table 4. Sample reach lengths and selected habitat characteristics of sites sampled in Whiskeytown National Recreation Area and nearby Clear Creek watershed, northwestern California, 2002-03.

[Site: See table 1 for description and location of sites. Mean dominant substrate: Substrate categories are: $1=$ smooth bedrock; $2=$ silt; $3=$ sand $(>0.063-2$ millimeters [mm]); 4=fine/medium gravel $(>2-16 \mathrm{~mm}) ; 5=$ coarse gravel $(>16-32 \mathrm{~mm}) ; 6=$ very coarse gravel $(>32-64 \mathrm{~mm}) ; 7=$ small cobble $(>64-128 \mathrm{~mm})$; $8=$ large cobble $(>128-256 \mathrm{~mm}) ; 9=$ small boulder $(>256-512 \mathrm{~mm}) ; 10=$ large boulder, irregular bedrock (Fitzpatrick and others, 1998). Abbreviation: $\mathrm{m}^{3} / \mathrm{s}, \mathrm{cubic}$ meter per second]

\begin{tabular}{|c|c|c|c|c|c|c|c|c|}
\hline Site & Year & $\begin{array}{l}\text { Reach } \\
\text { length } \\
\text { (meter) }\end{array}$ & $\begin{array}{l}\text { Discharge } \\
\left(\mathrm{m}^{3} / \mathrm{s}\right)\end{array}$ & $\begin{array}{l}\text { Mean depth } \\
\text { (meter) }\end{array}$ & $\begin{array}{l}\text { Mean dominant } \\
\text { substrate }\end{array}$ & $\begin{array}{c}\text { Riffle } \\
\text { (percent) }\end{array}$ & $\begin{array}{l}\text { Mean width } \\
\text { (meter) }\end{array}$ & $\begin{array}{l}\text { Mean open canopy } \\
\text { (degrees) }\end{array}$ \\
\hline BRAN & 2002 & 200 & 0.473 & 0.397 & 8.6 & 25 & 9.0 & 45 \\
\hline CCAR & 2002 & 200 & 1.088 & 0.516 & 5.5 & 40 & 14.0 & 100 \\
\hline FRGL & 2002 & 80 & 0.385 & 0.192 & 7.4 & 50 & 4.3 & 28 \\
\hline FSGL & 2002 & 80 & 0.012 & 0.027 & 6.9 & 100 & 1.8 & 9 \\
\hline GRZL & 2002 & 80 & 0.026 & 0.294 & 8.8 & 100 & 2.3 & 8 \\
\hline $\mathrm{H} 299$ & 2002 & 80 & 0.762 & 1.409 & 5.1 & 20 & 12.3 & 107 \\
\hline MCDS & 2002 & 80 & 0.045 & 0.100 & 7.6 & 40 & 4.3 & 13 \\
\hline MCUS & 2002 & 80 & 0.031 & 0.148 & 6.6 & 40 & 3.3 & 2 \\
\hline MDOX & 2002 & 80 & 0.018 & 0.065 & 8.0 & 100 & 3.1 & 23 \\
\hline NYGL & 2002 & 80 & 0.006 & 0.196 & 6.6 & 0 & 1.5 & 15 \\
\hline OCAC & 2002 & 80 & 0.003 & 0.030 & 4.3 & 0 & 2.6 & 111 \\
\hline OCCT & 2002 & 80 & 0.001 & 0.225 & 6.0 & 40 & 1.9 & 87 \\
\hline OCSM & 2002 & 80 & 0.001 & 0.059 & 4.8 & 0 & 1.1 & 60 \\
\hline PLTR & 2002 & 200 & 4.788 & 0.707 & 5.2 & 50 & 14.9 & 95 \\
\hline WCMM & 2002 & 80 & 0.111 & 0.257 & 7.0 & 60 & 4.3 & 25 \\
\hline WCWL & 2002 & 80 & 0.057 & 0.193 & 6.6 & 40 & 5.1 & 91 \\
\hline WLCC & 2002 & 80 & 0.068 & 0.211 & 5.8 & 20 & 3.5 & 60 \\
\hline WLTH & 2002 & 80 & 0.343 & 0.439 & 4.8 & 20 & 7.3 & 21 \\
\hline AMER & 2003 & 80 & 0.013 & 0.067 & 7.5 & 20 & 1.2 & 180 \\
\hline $\mathrm{CCCG}$ & 2003 & 200 & 5.150 & 0.699 & 5.7 & 25 & 16.8 & 82 \\
\hline CLN1 & 2003 & 80 & 0.357 & 0.273 & 7.4 & 20 & 4.3 & 55 \\
\hline CLN2 & 2003 & 80 & 0.391 & 0.337 & 8.7 & 20 & 3.0 & 15 \\
\hline FGCP & 2003 & 80 & 5.802 & 0.905 & 5.6 & 20 & 13.4 & 102 \\
\hline FGTP & 2003 & 80 & 4.213 & 0.692 & 6.0 & 20 & 18.1 & 109 \\
\hline LBGL & 2003 & 80 & 0.022 & 0.105 & 6.5 & 40 & 2.3 & 79 \\
\hline MMGL & 2003 & 80 & 0.011 & 0.165 & 4.7 & 20 & 1.6 & 113 \\
\hline MXUS & 2003 & 80 & 0.065 & 0.179 & 4.5 & 60 & 2.7 & 9 \\
\hline REDG & 2003 & 80 & 0.005 & 0.080 & 6.8 & 20 & 1.4 & 52 \\
\hline RFRG & 2003 & 80 & 0.227 & 0.321 & 7.3 & 20 & 2.8 & 12 \\
\hline SCRP & 2003 & 80 & 0.085 & 0.183 & 6.5 & 40 & 2.5 & 41 \\
\hline WCUM & 2003 & 80 & 0.329 & 0.301 & 6.0 & 20 & 3.7 & 44 \\
\hline
\end{tabular}


Table 5. Relative contamination by critical elements in invertebrates at sites sampled in Whiskeytown National Recreation Area and nearby Clear Creek watershed, northwestern California, 2002-03.

[Ranking of sites per year is based on the ratio of the geometric mean of concentrations for a given element in invertebrates at a given site to the median value for that metal at all sites (see methods). Overall ranking of sites was determined based on individual element rankings at each site, with the least contaminated sites at the top and the most contaminated sites at the bottom. Numbers presented are geometric means of concentrations in all invertebrates collected at that site. Site code: See table 1 for description and location of sites. Abbreviations: ND, not detected; As, arsenic; Cd, cadmium; $\mathrm{Cr}$, chromium; $\mathrm{Cu}, \mathrm{copper}_{\mathrm{Hg}}$, total mercury; Ni, nickel; Pb, lead; Se, selenium; Zn, zinc]

\begin{tabular}{|c|c|c|c|c|c|c|c|c|c|}
\hline \multicolumn{10}{|c|}{ COO2 } \\
\hline $\begin{array}{c}\text { Site } \\
\text { code }\end{array}$ & As & Cd & \multicolumn{1}{c|}{ Cu } \\
\hline BRAN & 1.826 & 0.160 & 4.111 & 27.30 & 0.022 & 0.738 & ND & 0.971 & 119.0 \\
\hline OCAC & 0.844 & 0.781 & 3.210 & 24.00 & 0.021 & 0.760 & 0.092 & 0.783 & 167.1 \\
\hline MCUS & 0.859 & 0.752 & 2.828 & 37.58 & 0.024 & 0.530 & 0.295 & 1.239 & 149.2 \\
\hline MCDS & 1.480 & 0.667 & 4.507 & 32.91 & 0.022 & 0.771 & 0.205 & 1.472 & 157.4 \\
\hline PLTR & 1.699 & 0.831 & 3.081 & 37.73 & 0.031 & 1.021 & 0.261 & 1.619 & 192.1 \\
\hline CCAR & 2.928 & 1.510 & 2.966 & 40.75 & 0.024 & 1.495 & 0.157 & 2.698 & 142.4 \\
\hline NYGL & 1.637 & 1.793 & 5.978 & 23.23 & 0.022 & 1.024 & 0.331 & 1.836 & 163.7 \\
\hline CDOC & 2.835 & 1.497 & 2.729 & 41.49 & 0.033 & 1.679 & 0.189 & 2.398 & 225.0 \\
\hline OCCT & 1.042 & 1.937 & 8.311 & 29.45 & 0.027 & 1.107 & 0.387 & 0.950 & 174.7 \\
\hline OCSM & 1.318 & 1.518 & 4.750 & 40.68 & 0.053 & 0.874 & 0.481 & 1.042 & 163.1 \\
\hline GRZL & 2.656 & 1.969 & 4.251 & 27.40 & 0.022 & 2.153 & 0.130 & 5.255 & 159.3 \\
\hline FSGL & 2.572 & 1.283 & 5.433 & 56.06 & 0.039 & 1.375 & 0.132 & 2.905 & 219.0 \\
\hline WLTH & 3.219 & 2.021 & 3.017 & 78.64 & 0.021 & 1.461 & 0.238 & 1.606 & 223.7 \\
\hline H299 & 4.217 & 1.609 & 4.411 & 32.57 & 0.041 & 2.418 & 0.357 & 2.954 & 153.2 \\
\hline SLCR & 2.184 & 2.512 & 3.323 & 27.94 & 0.033 & 4.818 & 0.240 & 3.382 & 177.8 \\
\hline MLPD & 3.096 & 1.899 & 2.277 & 21.64 & 0.054 & 2.811 & 0.566 & 4.734 & 89.1 \\
\hline WCWL & 4.245 & 3.627 & 2.507 & 23.52 & 0.036 & 2.595 & 0.119 & 6.509 & 155.8 \\
\hline WLCC & 4.017 & 2.412 & 6.760 & 88.71 & 0.020 & 1.841 & 0.256 & 1.878 & 201.8 \\
\hline WCMM & 3.656 & 4.603 & 3.763 & 29.84 & 0.039 & 2.379 & 0.243 & 5.502 & 220.7 \\
\hline MDOX & 1.389 & 5.323 & 2.745 & 33.22 & 0.056 & 1.147 & 0.593 & 4.372 & 249.5 \\
\hline FRGL & 5.803 & 2.460 & 3.416 & 32.78 & 0.059 & 2.278 & 0.430 & 5.397 & 191.5 \\
\hline
\end{tabular}

\section{COLORS REPRESENT THE RANKING SYSTEM}

\begin{tabular}{|l|l}
\hline HIGH & $(\geq 2$ MEDIANS $)$ \\
MEDIUM & $(1-1.99$ MEDIANS $)$ \\
LOW & $(<1$ MEDIAN $)$
\end{tabular}

\begin{tabular}{|c|c|c|c|c|c|c|c|c|c|}
\hline \multicolumn{7}{|c|}{$\mathbf{2 0 0 3}$} \\
\hline $\begin{array}{c}\text { Site } \\
\text { Code }\end{array}$ & As & Cd & \multicolumn{1}{c|}{ Cr } & \multicolumn{1}{c|}{ Hg } \\
\hline BRAN & 0.499 & 0.336 & 1.040 & 33.14 & 0.015 & 0.692 & 0.158 & 0.753 & 143.2 \\
\hline FGCP & 0.954 & 1.252 & 0.670 & 37.42 & 0.023 & 0.966 & 0.181 & 3.433 & 222.6 \\
\hline CCCG & 0.574 & 1.442 & 0.699 & 32.00 & 0.031 & 1.200 & 0.173 & 4.154 & 180.7 \\
\hline NYGL & 0.530 & 2.454 & 1.501 & 26.06 & 0.024 & 0.811 & 0.196 & 1.718 & 180.5 \\
\hline REDG & 0.631 & 3.971 & ND & 36.64 & 0.035 & 0.917 & 0.214 & 1.680 & 158.4 \\
\hline FSGL & 0.776 & 1.335 & ND & 52.44 & 0.036 & 0.551 & 0.237 & 2.972 & 175.9 \\
\hline CCAR & 1.183 & 1.804 & 0.558 & 37.95 & 0.026 & 1.522 & 0.206 & 2.708 & 157.5 \\
\hline LBGL & 0.553 & 4.056 & 0.634 & 58.65 & 0.020 & 0.798 & 0.182 & 1.863 & 190.8 \\
\hline MOXO & 0.867 & 0.885 & ND & 38.62 & 0.025 & ND & 0.550 & 1.532 & 226.4 \\
\hline FGTP & 1.001 & 1.589 & 0.789 & 37.50 & 0.035 & 0.664 & 0.283 & 3.541 & 237.3 \\
\hline MMGL & 1.090 & 3.328 & ND & 30.65 & 0.036 & 0.955 & 0.204 & 3.232 & 167.0 \\
\hline H299 & 0.936 & 1.270 & 1.180 & 32.70 & 0.035 & 1.154 & 0.232 & 2.840 & 199.6 \\
\hline GRZL & 0.884 & 1.750 & 1.172 & 39.81 & 0.030 & 1.138 & 0.248 & 4.258 & 215.1 \\
\hline CLN1 & 4.516 & 0.936 & 0.629 & 24.00 & 0.052 & 1.861 & 0.291 & 3.832 & 134.9 \\
\hline WCWL & 1.221 & 3.953 & 0.950 & 30.09 & 0.041 & 2.778 & 0.278 & 5.393 & 194.1 \\
\hline MXUS & 1.269 & 8.049 & 0.603 & 34.80 & 0.046 & 1.610 & 0.263 & 4.159 & 256.5 \\
\hline MDOX & 1.164 & 6.372 & 0.716 & 36.17 & 0.077 & 1.229 & 0.305 & 4.078 & 268.4 \\
\hline SLCR & 1.500 & 3.159 & 1.008 & 38.63 & 0.032 & 4.507 & 0.253 & 4.238 & 228.8 \\
\hline RFRG & 3.270 & 1.534 & 0.904 & 36.34 & 0.081 & 1.816 & 0.505 & 4.167 & 233.6 \\
\hline CLN2 & 2.782 & 3.131 & 0.769 & 35.01 & 0.100 & 1.726 & 0.442 & 4.349 & 222.5 \\
\hline WCUM & 1.188 & 6.230 & 1.282 & 35.23 & 0.031 & 3.533 & 0.331 & 5.145 & 279.9 \\
\hline WCMM & 1.214 & 6.308 & 0.831 & 37.98 & 0.044 & 3.672 & 0.340 & 4.911 & 299.2 \\
\hline AMER & 6.580 & 0.704 & 0.739 & 46.94 & 0.041 & 2.505 & 0.266 & 3.550 & 232.3 \\
\hline FRGL & 4.004 & 3.256 & 0.564 & 34.67 & 0.069 & 2.352 & 0.647 & 5.165 & 232.6 \\
\hline SCRP & 10.218 & 4.523 & 1.617 & 52.32 & 0.040 & 4.597 & 0.952 & 5.742 & 243.7 \\
\hline & & & & & & & & & \\
\hline
\end{tabular}


Table 6. Relative contamination by critical elements in fish at sites sampled in Whiskeytown National Recreation Area and nearby Clear Creek watershed, northwestern California, 2002-03.

[Ranking of sites per year is based on the ratio of the geometric mean of concentrations for a given element in fish at a given site to the median value for that metal at all sites (see methods). Overall ranking of sites was determined based on individual element rankings at each site, with the least contaminated sites at the top and the most contaminated sites at the bottom. Numbers presented are geometric means of concentrations in all fish collected at that site. Chromium (Cr) and nickel (Ni) were detected in too few samples in 2002 and 2003 to include in the analyses. Lead $(\mathrm{Pb})$ was detected in too few samples in 2002 to include in the analyses. Site code: See table 1 for descriptions and location of sites. Abbreviations: ND, not detected; As, arsenic; $\mathrm{Cd}$, cadmium; $\mathrm{Cu}$, copper; $\mathrm{Hg}_{\mathrm{T}}$, total mercury; Pb, lead; Se, selenium; Zn, zinc]

\begin{tabular}{|c|c|c|c|c|c|c|}
\hline \multicolumn{7}{|c|}{$\mathbf{\text { Cd }} \mathbf{\text { Cu }}$} \\
\hline $\begin{array}{c}\text { Site } \\
\text { code }\end{array}$ & As & \multicolumn{1}{c|}{ Hg $_{\text {T }}$} & Se & Zn \\
\hline BRAN & 0.370 & ND & 2.51 & 0.033 & 0.56 & 69.4 \\
\hline MCUS & 0.265 & 0.087 & 3.08 & 0.030 & 1.26 & 95.4 \\
\hline MCDS & 0.358 & 0.060 & 2.44 & 0.041 & 1.50 & 85.3 \\
\hline OCAC & 0.336 & 0.054 & 2.40 & 0.033 & 1.04 & 145.0 \\
\hline FSGL & ND & 0.171 & 2.99 & 0.039 & 2.22 & 81.0 \\
\hline OCSM & 0.263 & 0.113 & 2.68 & 0.032 & 1.29 & 185.2 \\
\hline CDOC & 0.290 & 0.118 & 3.22 & 0.037 & 2.91 & 84.0 \\
\hline WLTH & ND & 0.296 & 4.58 & 0.023 & 1.69 & 100.0 \\
\hline PLTR & 0.629 & 0.228 & 3.10 & 0.045 & 2.57 & 65.0 \\
\hline NYGL & 0.399 & 0.097 & 4.19 & 0.082 & 2.29 & 173.7 \\
\hline CCAR & 0.482 & 0.243 & 3.80 & 0.057 & 2.96 & 139.7 \\
\hline H299 & 0.545 & 0.278 & 2.94 & 0.077 & 3.69 & 121.0 \\
\hline GRZL & 0.402 & 0.339 & 2.89 & 0.082 & 5.23 & 131.0 \\
\hline MDOX & ND & 0.877 & 2.82 & 0.078 & 4.21 & 110.9 \\
\hline WCMM & 0.627 & 0.977 & 2.77 & 0.059 & 6.32 & 110.1 \\
\hline WCWL & 0.313 & 1.09 & 1.62 & 0.090 & 7.12 & 97.4 \\
\hline WLCC & 0.316 & 0.686 & 19.30 & 0.024 & 1.98 & 141.5 \\
\hline FRGL & 1.96 & 0.368 & 2.08 & 0.082 & 6.43 & 85.2 \\
\hline & & & & & & \\
\hline
\end{tabular}

\begin{tabular}{|c|c|c|c|c|c|c|c|}
\hline \multicolumn{8}{|c|}{2003} \\
\hline $\begin{array}{l}\text { Site } \\
\text { code }\end{array}$ & As & $\mathrm{Cd}$ & $\mathrm{Cu}$ & $\mathbf{H g}_{\mathrm{T}}$ & $\mathbf{P b}$ & $\mathrm{Se}$ & $\mathrm{Zn}$ \\
\hline BRAN & 2.10 & 0.104 & 2.78 & 0.038 & 0.189 & 0.72 & 78.1 \\
\hline FSGL & 2.29 & 0.242 & 3.76 & 0.046 & 0.129 & 2.52 & 79.1 \\
\hline CCAR & 1.84 & 0.204 & 4.16 & 0.048 & 0.102 & 3.00 & 130.5 \\
\hline LBGL & 1.27 & 0.409 & 7.10 & 0.013 & 0.056 & 1.76 & 164.9 \\
\hline $\mathrm{CCCG}$ & 1.82 & 0.441 & 2.77 & 0.034 & 0.102 & 3.78 & 140.1 \\
\hline GRZL & 2.26 & 0.315 & 2.76 & 0.060 & 0.091 & 3.76 & 147.0 \\
\hline H299 & 2.62 & 0.393 & 3.37 & 0.073 & 0.078 & 3.26 & 146.5 \\
\hline FGCP & 2.10 & 0.474 & 3.32 & 0.059 & 0.103 & 4.13 & 141.0 \\
\hline FGTP & 2.30 & 0.422 & 3.05 & 0.086 & 0.094 & 4.06 & 140.6 \\
\hline WCWL & 1.79 & 0.866 & 3.69 & 0.052 & 0.049 & 5.23 & 123.8 \\
\hline NYGL & 2.02 & 0.412 & 4.12 & 0.086 & ND & 2.59 & 337.4 \\
\hline WCMM & 1.92 & 0.962 & 4.11 & 0.051 & 0.103 & 5.40 & 115.9 \\
\hline CLN1 & 3.81 & 0.242 & 3.12 & 0.158 & 0.157 & 4.44 & 107.5 \\
\hline RFRG & 3.56 & 0.339 & 3.37 & 0.146 & 0.231 & 4.20 & 98.1 \\
\hline MDOX & 2.32 & 1.38 & 4.30 & 0.097 & 0.207 & 4.93 & 132.3 \\
\hline WCUM & 2.51 & 2.276 & 3.28 & 0.075 & ND & 6.74 & 166.7 \\
\hline SCRP & 7.78 & 0.766 & 5.48 & 0.050 & 0.236 & 5.49 & 100.7 \\
\hline FRGL & 5.41 & 0.738 & 4.41 & 0.086 & 0.317 & 6.83 & 106.1 \\
\hline CLN2 & 4.28 & 0.442 & 2.79 & 0.250 & 0.382 & 5.80 & 86.8 \\
\hline
\end{tabular}

COLORS REPRESENT THE RANKING SYSTEM

\begin{tabular}{|l|ll}
\hline & HIGH & $(\geq 2$ MEDIANS $)$ \\
MEDIUM & $(1-1.99$ MEDIANS $)$ \\
LOW & $(<1$ MEDIAN $)$
\end{tabular}




\section{Appendixes}

Appendixes 1-6 are Microsoft ${ }^{\circledR}$ Excel files and are available for download at http://pubs.usgs.gov/of/2015/1077.

Appendix 1. Metals and trace elements (in micrograms per gram [ $\mu \mathrm{g} / \mathrm{g}]$ ) in invertebrate composites from Whiskeytown National Recreation Area and nearby Clear Creek watershed, northwestern California, 2002-03.

Appendix 2. Water-quality parameters at Whiskeytown National Recreation Area and nearby Clear Creek watershed, northwestern California, 2002-03.

Appendix 3. Metals and trace elements (in micrograms per liter $[\mu \mathrm{g} / \mathrm{L}]$ ) in filtered (F) and raw (W) water samples, including North American Water Quality (NAWQ) criteria for toxicological benchmarks in water (Suter and Tsao, 1996), collected from Whiskeytown National Recreation Area and nearby Clear Creek watershed, northwestern California, 2002-03.

Appendix 4. Metals and trace elements (in micrograms per gram [ $\mu \mathrm{g} / \mathrm{g}]$, dry weight) in sediment samples, with sediment quality criteria (SQC) (Long and others, 1995), collected from Whiskeytown National Recreation Area and nearby Clear Creek watershed, northwestern California, 2002-03.

Appendix 5. Metals and trace elements (in micrograms per gram [ $\mu \mathrm{g} / \mathrm{g}]$ ) in individual bullfrogs (BF; Lithobates catesbeianus), Pacific chorus frogs (PACF; Pseudacris regilla), and foothill yellowlegged frogs (FYLF; Rana boylii) from Whiskeytown National Recreation Area and nearby Clear Creek watershed, northwestern California, 2002-03.

Appendix 6. Metals and trace elements (in micrograms per gram $[\mu \mathrm{g} / \mathrm{g}]$ ) in individual and composite samples of riffle sculpin (RSCP; Cottus gulosus), rainbow trout (RT; Oncorhynchus mykiss), and California roach (RCH; Hesperoleucus symmetricus) from Whiskeytown National Recreation Area and nearby Clear Creek watershed, northwestern California, 2002-03. 
This page left intentionally blank 
Publishing support provided by the U.S. Geological Survey

Science Publishing Network, Tacoma Publishing Service Center

For more information concerning the research in this report, contact the Director, Western Ecological Research Center

U.S. Geological Survey

3020 State University Drive East

Sacramento, California 95819

http://werc.usgs.gov/ 
